\title{
LAS PINTURAS DE EL MÉDANO, NORTE DE CHILE: 25 AÑOS DESPUÉS DE MOSTNY Y NIEMEYER
}

\section{THE EL MEDANO PAINTINGS OF NORTHERN CHILE: 25 YEARS AFTER MOSTNY AND NIEMEYER}

\section{José Berenguer R. *}

\begin{abstract}
Pese a su carácter de divulgación, los trabajos de Grete Mostny y Hans Niemeyer $(1983,1984)$ constituyen el primer estudio científico de las pictografías de El Médano, una remota quebrada de la costa del norte de Chile que contiene más de un millar de imágenes marinas y terrestres, incluyendo escenas de pesca y caza colectiva desde embarcaciones y caza de guanacos con flechas. Se argumenta que los datos e interpretaciones presentados por estos investigadores plantean problemas y abren interrogantes de relevancia tanto para la prehistoria tardía de la costa desértica del norte de Chile como para los actuales estudios de arte rupestre.

Palabras clave: costa del desierto de Atacama, balsa de cuero de lobo, aproximaciones al arte rupestre, divulgación científica
\end{abstract}

Despite being written for the general public, the publications of Grete Mostny and Hans Niemeyer (1983, 1984) offer the first scientific study of the pictographs of El Médano, a remote coastal ravine in northern Chile that contains more than a thousand marine and terrestrial images, including scenes of group bunting and fishing from seagoing vessels and guanaco bunting with arrows. It is argued that the data and interpretations offered by the aforementioned researchers present problems and raise questions that are pertinent both to the late prebistory of the northern Chilean desert coast and to current studies of rock art.

Key words: Atacama Desert coast, sea lion skin raft, approaches to rock art, popularization of science
Situada entre Antofagasta y Taltal, a unos $20 \mathrm{~km}$ al norte de la caleta Paposo, El Médano es una de las muchas quebradas que nacen en la cordillera de la Costa y caen a la planicie litoral (fig. 1). Lo que hace única a esta quebrada es su arte rupestre, uno de los más singulares de la costa del Pacífico sudamericano. Prácticamente desde su cabecera, a casi $2000 \mathrm{msnm}$, hasta que desemboca a 1200 msnm en el farallón costero, se suceden más de dos centenares de paneles con pictografías a lo largo de la primera mitad de los $10 \mathrm{~km}$ de extensión que tiene la vaguada (fig. 2). A ambos lados del tal veg de la quebrada y de otra menor llamada El Medanito, sobre bloques sueltos y paredones rocosos, hay más de mil imágenes pintadas en rojo. Peces, cetáceos, tortugas, lobos de mar y otros animales marinos aparecen representados solos o en grupos, muchas veces arrastrados por diminutas balsas de cuero de lobo, en llamativas escenas de pesca y caza colectiva (fig. 3). En menor cantidad aparecen también cánidos y cazadores flechando camélidos. Estas pictografías ofrecen un acercamiento único a los valores estéticos, el pensamiento y las estrategias de subsistencia de los grupos pescadores, cazadores y navegantes que habitaron las costas del desierto de Atacama, al parecer durante el último milenio de la secuencia cultural prehispánica. ${ }^{1}$

El yacimiento pictográfico fue reportado por primera vez por Augusto Capdeville (2008 [1923]) y localizado en un mapa por un pariente suyo en 1956 (Larraín 1974:

* José Berenguer R., Curador Jefe del Museo Chileno de Arte Precolombino, Casilla 3687, Santiago de Chile, email: jberenguer@museoprecolombino.cl 


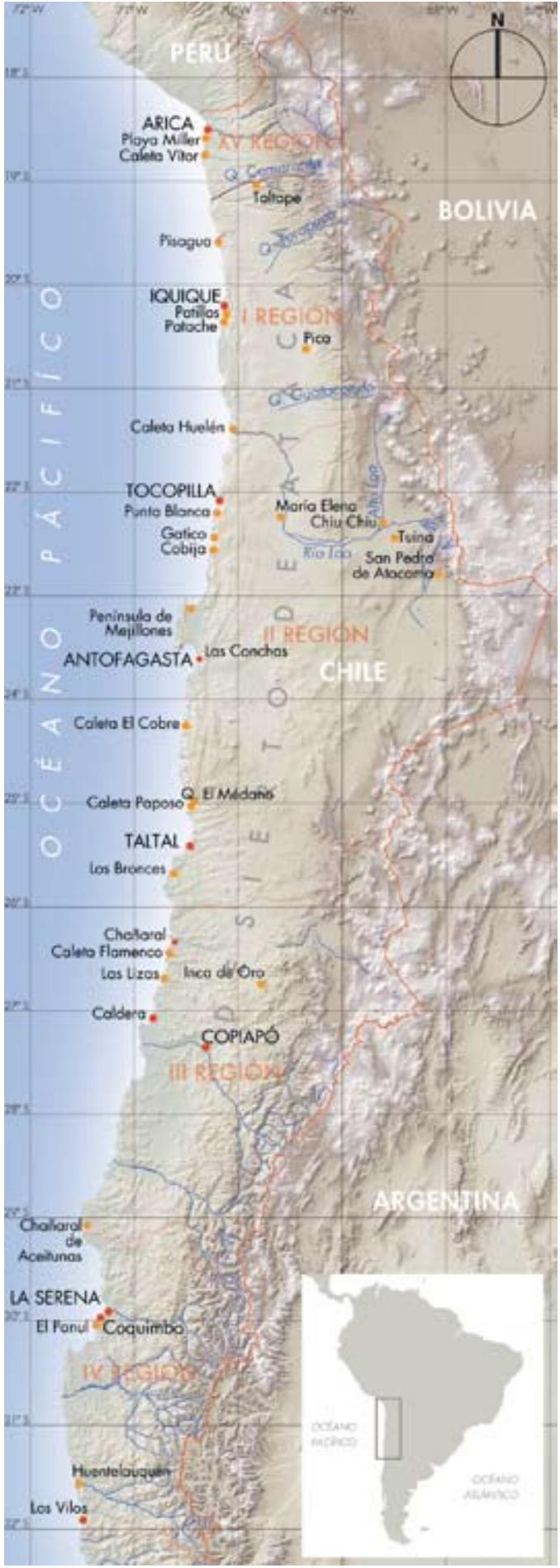

Figura 1. Mapa del norte de Chile con la localización de la quebrada El Médano y otros lugares mencionados en el artículo (producción: F. Maldonado sobre base topográfica cortesía del Laboratorio SIG CASEB, Pontificia Universidad Católica)

Figure 1. Map of northern Chile with the location of El Médano ravine and other places mentioned in the article (produced by F. Maldonado using relief maps provided by Laboratorio SIG CASEB, Pontificia Universidad Católica).

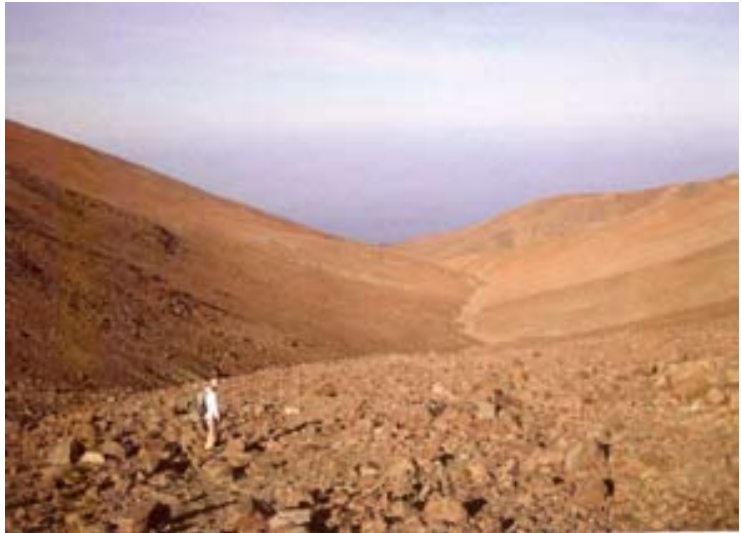

Figura 2. Quebrada El Médano vista desde su cabecera, casi al borde del desierto (foto: J. Berenguer).

Figure 2. Head of El Médano ravine, close to the edge of the desert (photo: J. Berenguer).

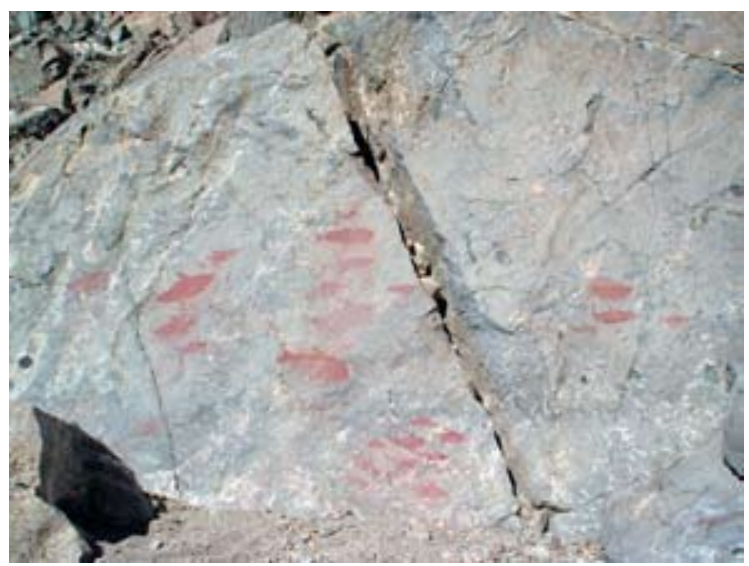

Figura 3. Pictografías en quebrada El Médano, paneles 33-A y 33-B (foto cortesía H. Gárate).

Figure 3. Pictographs in El Médano ravine, panels 33-A and 33-B (photo courtesy of H. Gárate).

Nota 23) como "Piedras Pintadas de la Quebrada Médano" (véase Mostny 1964, T. I: Plano III). ${ }^{2}$ La información de Capdeville pasó inadvertida durante 50 años, hasta que un oportuno dato del geólogo Guillermo Chong condujo a Hans Niemeyer a registrar y relevar las pinturas en 1973. Si bien el hallazgo fue comunicado brevemente al medio académico en sendos artículos sobre las variaciones estilísticas del arte rupestre de Chile (Niemeyer 1977, 1980), es más conocido por un par de trabajos de divulgación científica que el autor publicara con Grete Mostny en los años ochenta: Arte rupestre chileno, un libro de síntesis editado por el Ministerio de Educación, en el que los autores analizan en forma comparativa estas pictografías dentro de un conjunto de nueve estilos de arte rupestre del país (Mostny \& Niemeyer 1983) y 
"Arte rupestre en El Médano, II Región”, un artículo de cinco páginas publicado en la desaparecida Revista Creces, específicamente consagrado a las pinturas que comentamos (Mostny \& Niemeyer 1984). ${ }^{3}$

Durante las pasadas dos décadas y media este par de trabajos han sido la principal fuente disponible sobre este interesante yacimiento de pictografías. Sería injusto disminuir su importancia científica por tratarse de textos dirigidos al público general, o bien, por presentar ideas tan complejas basadas en datos tan sucintos y obviamente preliminares. En mi opinión, la información y las interpretaciones que ofrecen plantean problemas y abren interrogantes que son de relevancia actual para la arqueología del poblamiento tardío de la costa desértica del norte de Chile y para los estudios de arte rupestre y de los sistemas de representación visual andinos en general. Permítaseme fundamentar estas afirmaciones con un análisis de algunos de los principales pasajes de esas publicaciones.

Sin ninguna pretensión de agotar el tema, me referiré en este análisis a cuatro amplios tópicos considerados por Mostny y Niemeyer (1983, 1984): 1) estilo, cronología y distribución espacial de las pictografías, 2) identificación de las imágenes, 3) propósito del sitio y sus pictografías y 4) identidad étnica o cultural de los pintores de El Médano. Para actualizar, completar y contextualizar mi análisis, intercalaré datos publicados con posterioridad por otros autores, información publicada e inédita del propio Niemeyer y comunicaciones personales de otros actores involucrados. Aprovecharé también de sugerir algunas ideas a partir de ciertos temas expuestos en las mencionadas publicaciones. Antes, sin embargo, me extenderé sobre la naturaleza del material inédito de Niemeyer.

\section{PALABRAS INCONCLUSAS, DIBUJOS OLVIDADOS}

Desde la publicación del libro y el artículo con Mostny, Niemeyer nunca dejó de pensar en las pictografías de El Médano. Inicialmente, las comparó con los petroglifos del yacimiento de Las Lizas, localizado entre Chañaral y Caldera (Niemeyer 1985: 144-145), más adelante propuso paralelos etnográficos para identificar algunos motivos presentes en la quebrada (Niemeyer 1989b), en 1985 y 1990 emprendió dos nuevas expediciones a la quebrada. A lo largo del tiempo encargó análisis a diversos especialistas y trabajó en los originales de los dibujos de los paneles, en 2001 ganó una Beca Guggenheim de apoyo a la publicación y en sus años finales alcanzó a redactar varios capítulos de la monografía con la que pensaba concluir la investigación. En 2004 consiguió que el Museo Chileno de Arte Precolombino se hiciera cargo de esta monografía, tarea en la que trabajó con su editor, Francisco Gallardo, hasta su fallecimiento en 2005. El libro se halla prácticamente editado, aunque su publicación se ha retrasado por diversas razones. ${ }^{4}$

El legajo de documentos facilitado por Niemeyer a Gallardo para este proyecto editorial comprende una serie de manuscritos sin terminar, que no han sido incluidos en su libro póstumo. Con motivo de la invitación que me hizo este último a escribir el prólogo de dicho libro a fines de 2006, los revisé para interiorizarme de sus métodos de trabajo, de las campañas que efectuó a la quebrada, de las pericias encargadas por él a otros analistas y de reflexiones del autor sobre diferentes temas. A pesar del carácter fragmentario e inacabado de este material, que lo hace en muchos casos difícil de publicar, contiene, en mi concepto, información que complementa el material considerado en el libro y que revela, de paso, el plan original que Niemeyer tenía para la obra. En el presente artículo procuraré incorporar algunas ideas contenidas allí, incluyendo opiniones de especialistas que él consultó a través de los años. Al referirme a este tipo de manuscritos inéditos, usaré un título breve entre comillas (p. e., "El Estilo El Médano").

Otra contribución importante son las ilustraciones. El dibujante Jorge Bórquez cuenta que después de cada expedición, las imágenes de arte rupestre solían llegar a la oficina de Niemeyer en croquis, fotos en blanco y negro, y diapositivas en color. ${ }^{5}$ Cuando los paneles eran muy extensos, Niemeyer tomaba series de fotos solapadas, las que eran compuestas en el tablero de dibujo. Según el dibujante, el procedimiento de traspaso era muy sencillo: con lápiz de grafito trasladaba las figuras y la escala gráfica a papel vegetal mediante un pantógrafo; luego, con un Rapidograph de 0.2 o 0.3 mm, punteaba a tinta china las siluetas así obtenidas. La mayor o menor densidad de puntos expresaba variaciones en la intensidad del color en las pictografías. Basándose en los croquis y el material fotográfico, ambos corregían cuantas veces fuese necesario, hasta dejar los dibujos en condiciones de publicar.

Fruto de este trabajo son 71 fotocopias en blanco y negro de los dibujos hechos por Bórquez bajo la supervisión de Niemeyer. ${ }^{6}$ Están organizados por láminas y éstas, por bloques o grupos, categorías que aquí asimilaré a paneles. Los soportes de las pinturas son bloques sueltos de granodiorita (fig. 4a) y "diques" de andesita (fig. 4b) que atraviesan la quebrada y "cortan la diorita" ("Crónica del rescate"). 

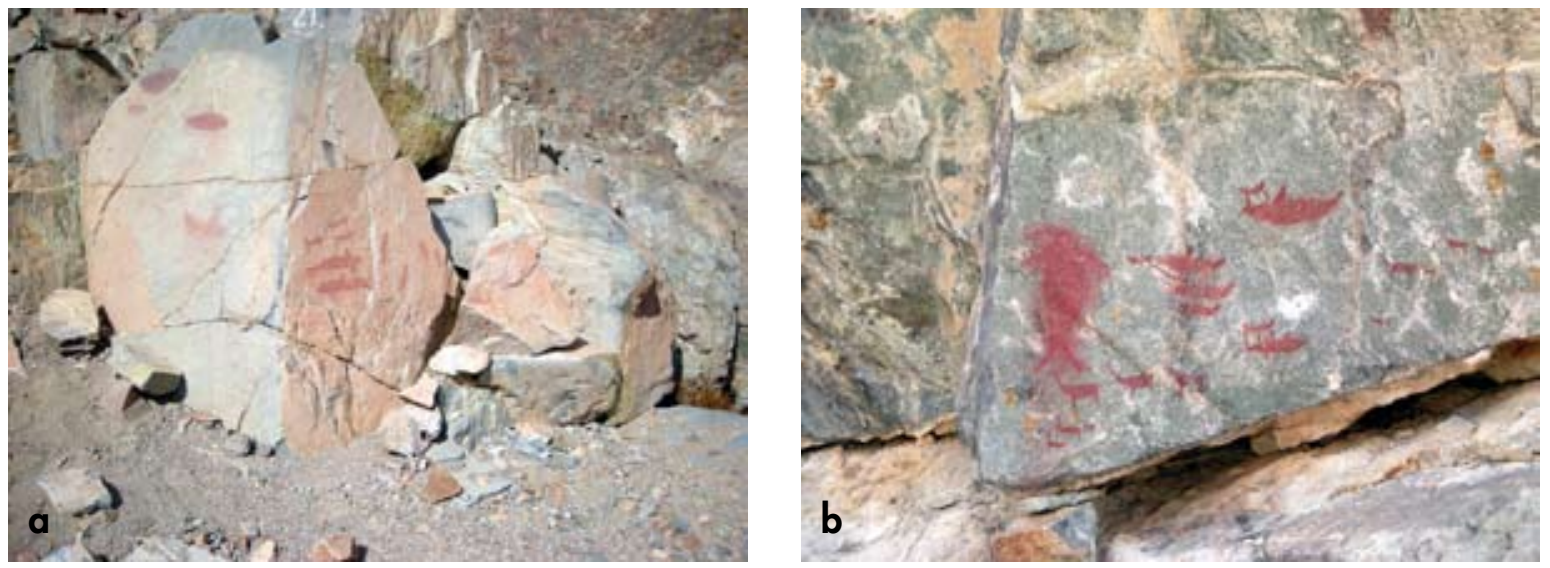

Figura 4. Pictografías: a) en granodiorita; b) en andesita (fotos: J. Berenguer).

Figure 4. Pictographs: a) on granodiorite; b) on andesite (photos: J. Berenguer).

La numeración de los paneles corresponde al orden en que los encontró. En "Crónica del rescate" explica que si los bloques o grupos poseen más de una cara con pinturas, diferencia estas facetas con una letra mayúscula, aunque no aclara por qué ocupa números en modo de subíndice al final de algunos de estos códigos. En total, las fotocopias documentan 51 unidades, considerando bloques/grupos individuales y agrupamientos mayores, que denomina "conjuntos".

Los dibujos están a medio concluir, ya que contienen observaciones manuscritas, pero no dispongo de información confirmada acerca del destino que corrieron los originales. En cualquier caso, las fotocopias tienen valor documental, no sólo porque parecen ser lo único que ha sobrevivido de ese trabajo, también porque proporcionan una información inapreciable sobre los aspectos estilísticos y el repertorio icónico de lo que pareciera ser casi la totalidad de las pinturas levantadas por Niemeyer en $1973 .^{7}$

Las referencias a pictografías específicas que hago en el análisis que sigue, se basan esencialmente en este material fotocopiado. Algunos dibujos son bien conocidos; otros, en cambio, son reproducidos por primera vez en el presente artículo. El libro, que aparecerá pronto, incluye también dibujos no publicados con anterioridad, pero la mayoría de las ilustraciones encargadas por Niemeyer a Bórquez permanecerá inédita quién sabe por cuánto tiempo más.

\section{ESTILO, TIEMPO Y ESPACIO}

La definición de estilos, el establecimiento de una cronología y la distribución espacial son procedimientos básicos en cualquier investigación del arte rupestre que se haga desde una perspectiva arqueológica. Como veremos de inmediato, estas preocupaciones taxonómicas y contextuales se hallan bien representadas en los dos trabajos de nuestros autores (véase también Niemeyer 1977).

\section{Las pinturas como estilo}

Mostny y Niemeyer (1983: 15, 1984: 3-4) definen brevemente el arte rupestre de El Médano como un arte naturalista que reproduce "con técnica de pintura llana, en tintes exclusivamente rojos", "escenas de caza marina desde balsas de cuero de lobo y de caza terrestre de guanacos con enfrentamientos de arqueros". A diferencia de como lo hacen en el libro (Mostny \& Niemeyer 1983) y de como lo había hecho el propio Niemeyer (1977, 1980) en algunas comunicaciones científicas previas, en el artículo sobre El Médano Mostny y Niemeyer (1984) evitan usar la palabra "estilo" para referirse al conjunto de estas pictografías. Es posible que la omisión obedezca a las reservas que, al parecer, Mostny tenía frente a este concepto como una herramienta ordenadora en arte rupestre (véase Carmona 2003: 167). No obstante, en el manuscrito inédito "El Estilo El Médano" es claro que Niemeyer siempre pensó en mantener este concepto en su monografía final. ${ }^{8}$

En el manuscrito "El Estilo El Médano", Niemeyer aporta información técnica no contenida en las publicaciones que comentamos. Dice que los pigmentos colorantes corresponden a hematita y que el disolvente fue agua, no aceite de lobo de mar o de cetáceo, como pensaba. En el manuscrito "Naturaleza de los pigmentos" precisa que extrajo ocho muestras de pintura para análisis 
por difracción de rayos X y espectrometría infrarroja, los que arrojaron presencia de hematita u óxido férrico y ausencia de moléculas orgánicas. ${ }^{9}$ Niemeyer conjetura que primero los artífices de este arte rupestre molían el mineral de origen, en general fácilmente deleznable; en seguida lo mezclaban con agua formando una suspensión más o menos espesa; finalmente, aplicaban esta suspensión -quizás con los dedos o con manojos de pelos en forma de hisopos o pinceles- a una superficie tal vez previamente humedecida.

Salvo casos de deterioro producidos por la luz solar y tal vez por el impacto de partículas de arena transportadas por el viento o la acción de otros agentes mecánicos, como las aguas que bajan en forma episódica por la quebrada, las pinturas se encuentran relativamente bien conservadas, por lo que queda la duda si el tipo de disolvente hipotetizado por Niemeyer habría resistido en tan buena forma las cíclicas lluvias que afectan a esta zona (véase infra). Podría pensarse que algunas pictografías que presentan sus pigmentos difuminados más allá del contorno de las figuras, lo están por efectos de estas precipitaciones, pero su aspecto areolar y su carácter selectivo sugieren, más bien, frotamiento por acción humana (véase fig. 4b, extremo izquierdo). En cualquier caso, hay allí un tema por investigar, ya que no se ha confirmado si todas o sólo algunas de las pictografías tienen pigmentos carentes de moléculas orgánicas. Se desconoce también si las pictografías visibles en la actualidad constituyen el conjunto original una vez que cesó la actividad rupestre en la quebrada o sólo las que se han conservado hasta nuestros días. Los caudales que descienden por la quebrada pueden haber removido bloques de su lugar; de hecho, se observan algunos de ellos con sus imágenes parcial o totalmente volcadas. De ahí que es pertinente preguntarse si hay bloques con pinturas que hayan sido despeñados por las aguas hasta la base del farallón costero.

De modo similar al resto de los estilos de petroglifos y pictografías del desierto de Atacama (Gallardo et al. 1999; Berenguer 2004b), el arte rupestre de El Médano es figurativo prácticamente en su totalidad. Es decir, pese a que sus imágenes no superan el nivel de "pictogramas" en la escala de iconicidad (Villafañe \& Mínguez 2000: Fig. 31), en casi todas ellas es posible reconocer su referente en la realidad primaria con diversos grados de aproximación. Son imágenes resueltas con economía o simplicidad, puesto que están construidas por un pequeño número de características estructurales, independiente de la complejidad de los referentes. Por otra parte, dado que nunca es posible tener acceso de una sola vez a la apariencia total de un objeto, los pintores de El Médano -como muchos otros artistas plásticos- se vieron forzados a seleccionar el punto de vista más adecuado para facilitar el reconocimiento del referente. Así, las tortugas y las rayas (fig. 5) son representadas en proyección cenital, en cambio los cetáceos y los peces lo son en proyección de perfil y a veces con el apéndice caudal en posición vertical, como si el pintor hubiera querido captar a los animales "por el ángulo desde el cual se advierte más claramente su forma característica" (Gombrich 1999: 574). Únicamente los lobos marinos son mostrados tanto en proyección cenital como de perfil (fig. 6). Las especies marinas aparecen en forma animada, flotando en su medio acuático y con el movimiento de su cuerpo congelado en la acción, como en una instantánea fotográfica. Las especies capturadas, en cambio, parecen tener menos animación, aunque ésta no es la regla general.
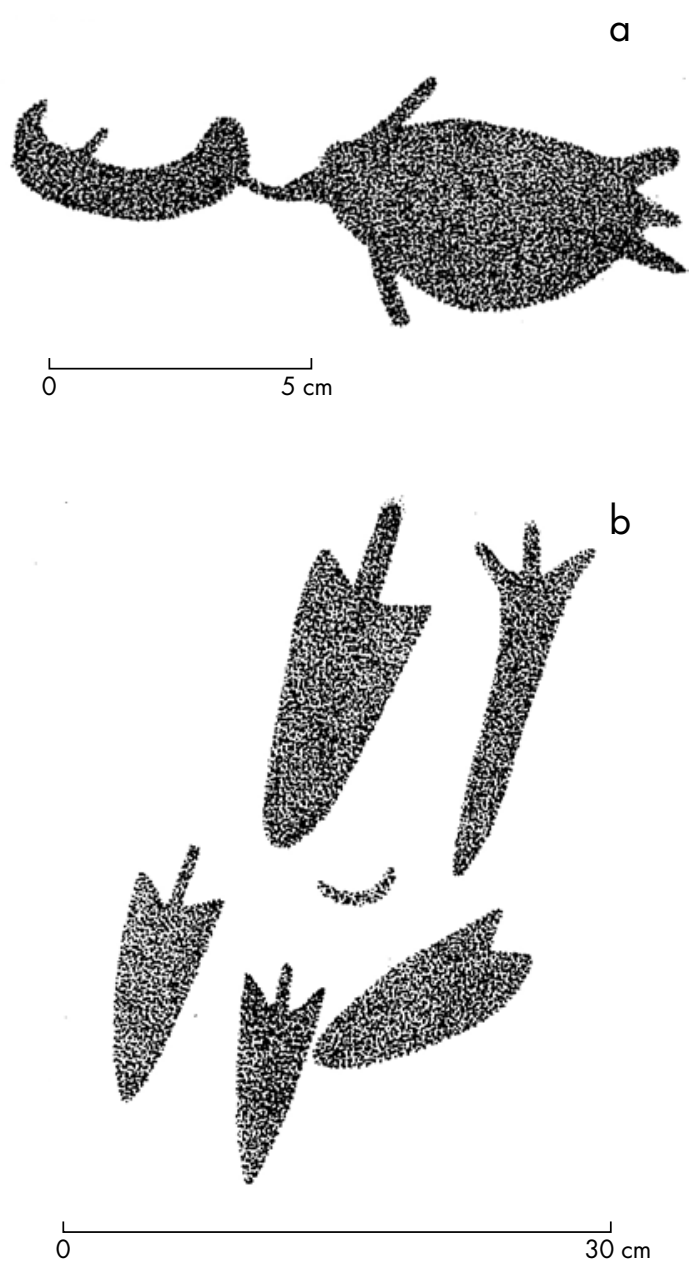

Figura 5. a) Tortuga arrastrada por balsa de cuero de lobo marino (panel 20-D); b) rayas (panel 29-XVII).

Figure 5. a) Sea turtle being dragged by a sea lion skin raft (panel 20-D); b) sting rays (panel 29-XVII). 
a

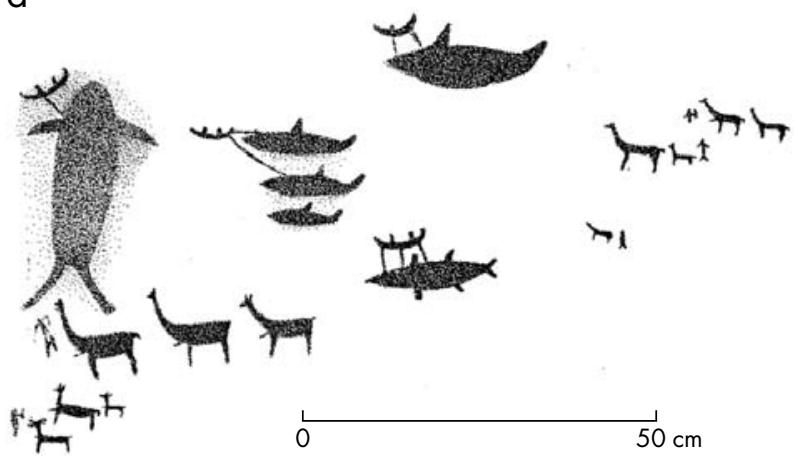

$b$

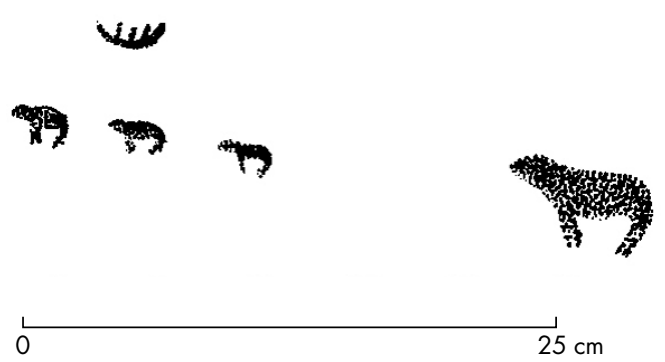

Figura 6. Lobos marinos: a) a la izquierda arriba, en proyección cenital (panel 34-B; b) en proyección de perfil (panel 29-J J $_{8}$. Figure 6. Sea lions: a) upper left, frontal view (panel 34-B; b) and profile view (panel 29-J ${ }_{8}$ ).

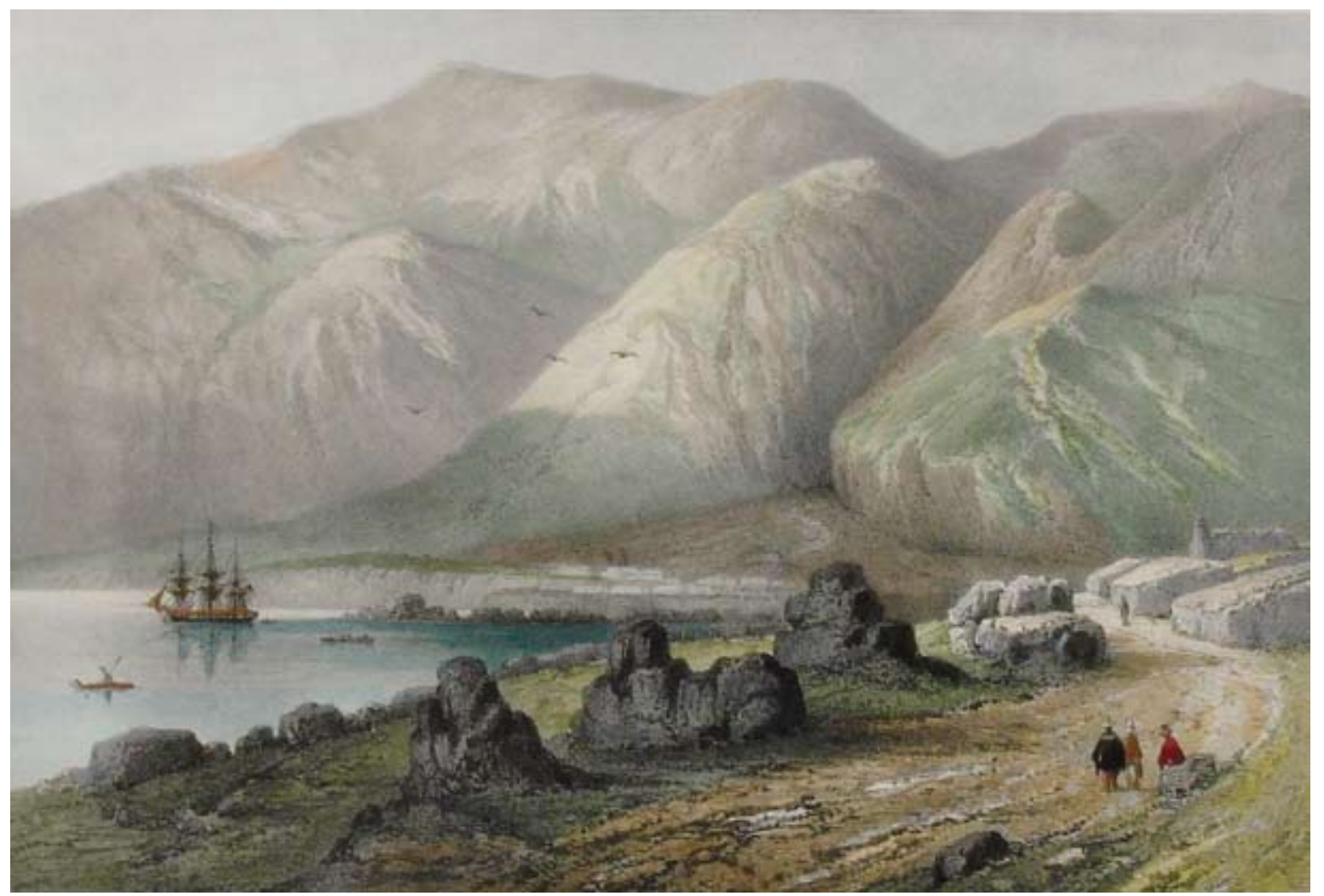

Figura 7. A la izquierda, balsa de cuero de lobo en el puerto de Cobija (grabado de Gabriel Lafond 1843).

Figure 7. On the left, sea lion skin raft in the port of Cobija (engraving by Gabriel Lafond, 1843).

Las representaciones de tripulantes, en tanto, suelen ser minúsculas y menos precisas o definidas que la mayoría de los animales (fig. 3), cuestión que, dada la destreza de que hacen gala los pintores al plasmar otras figuras, es difícil atribuirla a una incapacidad para representarlas. Tal parece que las reglas y convenciones estilísticas de los artistas de El Médano exigían representar a los balseros como meras líneas verticales o conos.
Extremando la interpretación, podría ser que los primeros correspondan a individuos erguidos en la embarcación y los segundos a tripulantes sentados, como aparecen en numerosos grabados de la época histórica (fig. 7), o bien, arrodillados sobre ella, como dice Capdeville que los describió su informante de Paposo (Contreras \& Núñez 2009: 93). Sea como fuese, son diseños en los que se llega a un esquematismo rayano en la abstracción. 
Distinto es el caso de los cazadores de camélidos, los que, pese al esquematismo con que se les representa, incluyen cabeza, brazos y piernas bien diferenciados (véase fig. 6a, izquierda abajo y extremo derecho).

Cuando se examinan las pinturas en términos de escenas, éstas revelan una "mirada caleidoscópica" (Iwasaki 2007), en el sentido de que cada pintor parece desplazarse buscando diversos ángulos, creando a veces múltiples representaciones de un tema único. Es el caso, principalmente, de las balsas arrastrando presas marinas (fig. 3) y de los arqueros flechando camélidos (fig. 6a). En aquellas que muestran lobos marinos de perfil, nadando solos o en grupos de tres o más individuos (fig. 6b), pareciera que los pintores se "colocan" en un ángulo de visión a nivel del mar, como si estuvieran en la playa o a bordo de una embarcación. En otras escenas, en cambio, como las de balseros remolcando cetáceos o tortugas y las de algunos cardúmenes y tortugas individuales (fig. 5a), los artistas se "sitúan" en ángulos de mirada de unos $45^{\circ}$ a $60^{\circ}$. Estas visuales son imposibles de obtener desde cualquiera de los bajos cabos rocosos que sobresalen del perfil costero inmediato a la quebrada de El Médano o desde los islotes que se desprenden de ellos. Para obtenerlas, hay que ir a promontorios altos, como los que se hallan en Taltal y sus inmediaciones.

A juzgar por lo que se aprecia en los dibujos de Niemeyer y lo observado por mí durante el día y medio que estuve en la quebrada, en El Médano no hay casos de superposición de pictografías o de figuras que se recorten unas con otras, como sucede, por ejemplo, con las "transparencias" que caracterizan a los pictograbados del sitio-tipo de Taira (Berenguer 1996: 92-95). Las imágenes en los paneles aparecen plasmadas como figuras discretas, donde, si hubo pinturas posteriores de los mismos u otros pintores, éstas dejaron intactas las obras precedentes. Si a esto agregamos que la densidad de figuras no es alta en los paneles, el resultado son composiciones bien "ventiladas" desde el punto de vista de la ocupación del espacio pictográfico.

Se observan, eso sí, diversas relaciones espaciales de yuxtaposición entre figuras en un mismo panel. Un primer caso, es la representación de balsas arrastrando grandes presas marinas. El mecanismo constructivo de la imagen es una yuxtaposición del tipo "unión vinculada" (sensu Colle 1998), porque la línea del arpón produce una relación de dependencia entre ambas figuras. Que remos y arpones sean invisibles, no significa que estos implementos no hayan estado en la mente del pintor (Gombrich 1999); simplemente su cultura visual no consideró que estos rasgos fuesen pertinentes al mensaje icónico. Los primeros se infieren del contexto y los segundos de la línea que une a la balsa con el cuerpo del animal. Un ejemplo algo más complejo de unión vinculada es el de una balsa remolcando tres presas, una de las cuales parece devorar a un lobo marino (fig. 8, arriba). ${ }^{10}$ Otro tipo de relación estructural por yuxtaposición es la "unión asociativa" (sensu Colle 1998). El caso más claro es el de arqueros emboscando con sus armas a tropillas de camélidos que se desplazan en sentido contrario (fig. 6a); el proyectil que algunos de los animales tienen clavado en el pecho completa la unión asociativa como una sola unidad de representación. Un último ejemplo de este tipo de unión son las escenas de peces o cetáceos más o menos de igual tamaño, desplazándose en la misma dirección a modo de cardúmenes (fig. 3, abajo, y fig. 9).

Dentro de los códigos visuales de las pictografías están los alineamientos y las repeticiones de figuras unas al lado de las otras (lobos marinos, camélidos) o unas encima de las otras (peces o cetáceos) (figs. 3 y 6a). Estas simetrías por traslación generan un ritmo por semejanza en la composición de las escenas, que se reitera en varios paneles. Otro de estos códigos es la mantención de la escala entre figuras similares que comparten un panel (fig. 10a). Hay situaciones en que se viola esta norma (fig. 10b), pero esto no ocurre la generalidad de las veces. Incluso, cuando hay paneles que presentan escenas de arqueros cazando camélidos junto con escenas de balseros remolcando presas
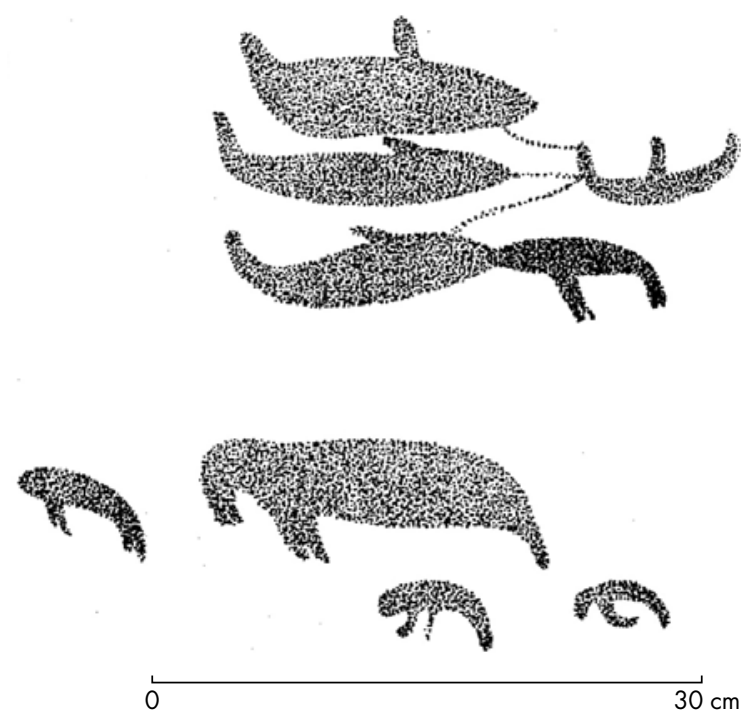

Figura 8. Arriba, ejemplo de unión vinculada compleja consistente en una balsa remolcando tres presas capturadas, una de las cuales devora un lobo marino (panel 4-A).

Figure 8. Above, example of a complex joined linkage consisting of a raft towing three captured prey, one of which is devouring a sea lion (panel 4-A). 
marinas, por lo común existe cierta proporción entre todas las figuras.

En síntesis: el uso exclusivo de pigmentos rojos en la realización de las pictografías de El Médano, el carácter esencialmente figurativo o analógico de éstas, los

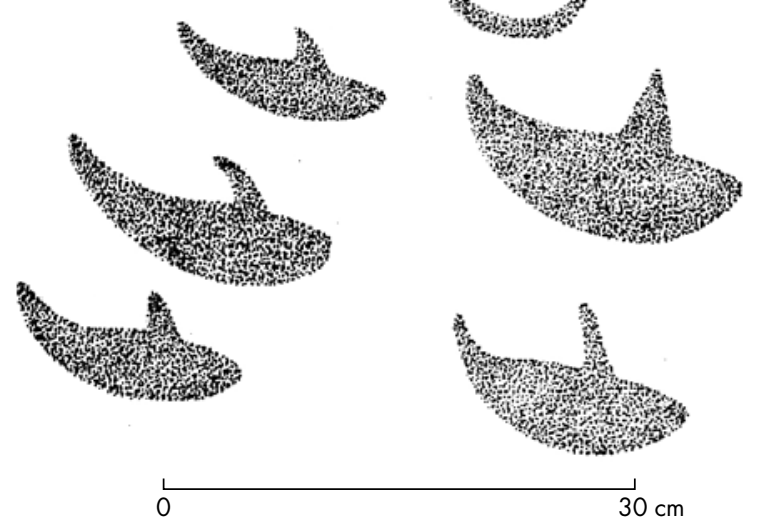

Figura 9. Cardumen como ejemplo de unión asociativa (panel 29-J $\mathrm{J}_{9}$.

Figure 9. Cardumen as an example of associated linkage (panel $\left.29-J_{9}\right)$.

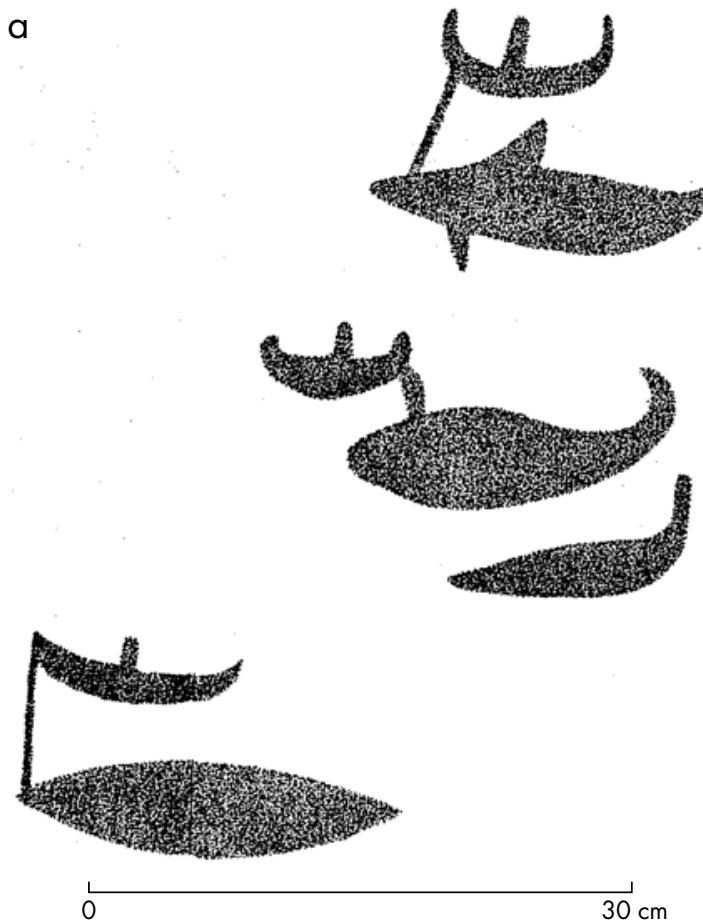

motivos y temas compartidos por los diferentes paneles de la quebrada, los principios constructivos ocupados al plasmarlos como figuras individuales o compuestas y la configuración que estas imágenes adoptan en la superficie del panel, sugieren, en conjunto, la existencia de una misma firma visual. En consecuencia, la revisión del material fotocopiado me lleva a concluir que Mostny y Niemeyer (1983) aciertan cuando definen a las pinturas de El Médano como un estilo en su propio derecho. Se advierte, por cierto, alguna diversidad entre las pinturas a través de la quebrada, pero nada, al parecer, que no pueda atribuirse a diferencias idiosincráticas entre los pintores y/o a cambios a través del tiempo dentro de una misma tradición estilística (fig. 11). El único elemento anómalo son ciertas posibles figuras esquemáticas de instrumentos de caza marina, de balsas y de tripulantes cuyos "brazos" escapan a la norma ocupada para representar la figura humana en las escenas oceánicas y que trataremos más adelante. En cualquier caso, la definición estilística es un problema que deberá ser revisado con mayor detalle por los investigadores, mediante enfoques, conceptos, instrumentos y relevamientos más precisos.

b

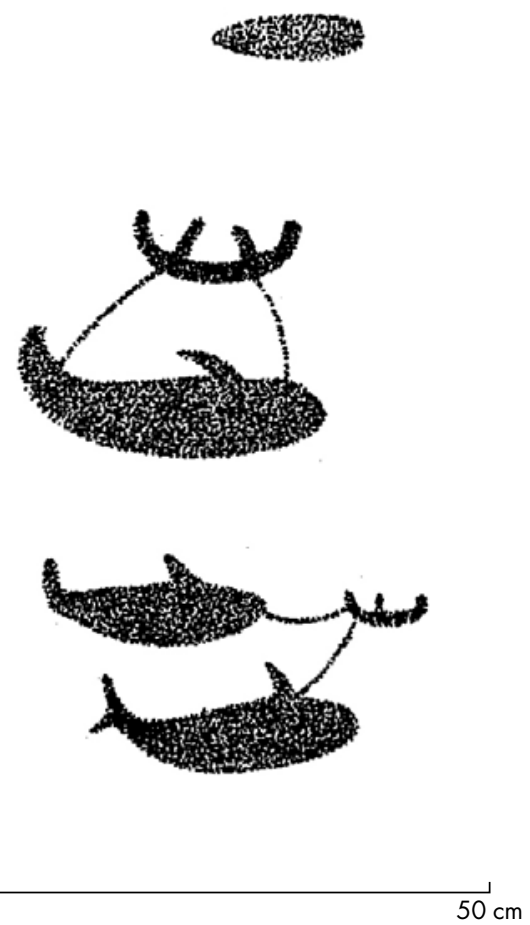

Figura 10. Balsas: a) que guardan la misma proporción entre sí (panel 16a); b) balsas que guardan distinta proporción (panel 23-24). Figure 10. Rafts: a) rafts of similar proportion (panel 16a); b) rafts of different proportions (panel 23-24). 


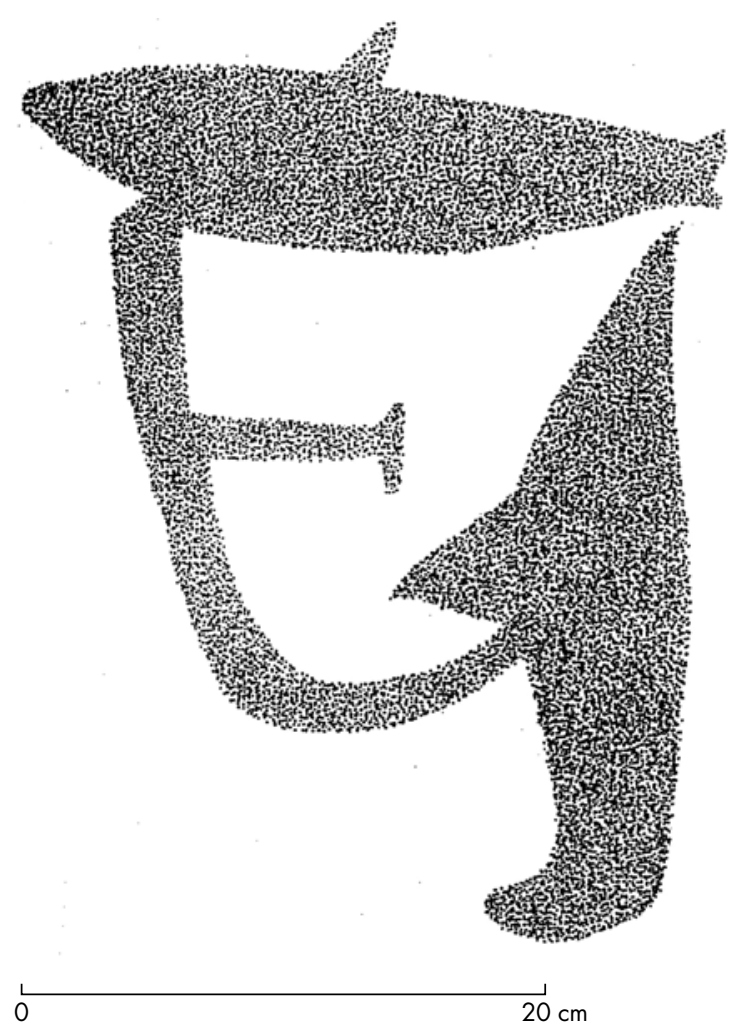

Figura 11. Posible caso de variación idiosincrática o temporal en las pictografías de El Médano (panel 15-C).

Figure 11. Possible case of idiosyncratic or temporal variation in the El Médano pictographs (panel 15-C).

\section{Las pinturas en el tiempo}

Niemeyer no encontró sitios de habitación o cementerios en la quebrada o en la planicie costera que le ayudasen a contextualizar y fechar en forma indirecta las pinturas. ${ }^{11}$ Aun así, él y Mostny avanzaron la hipótesis de que las pinturas de El Médano datan de la primera mitad del segundo milenio de la Era Cristiana.

Las balsas de cuero de lobo que se reproducen en las escenas de pesca en El Médano, empiezan a utilizarse con el desarrollo de la Cultura Arica (siglos X-Xv después de Cristo), de tal forma que las pinturas cuentan aproximadamente con una edad de 500 a mil años a la fecha (Mostny \& Niemeyer 1984: 5; véanse también Mostny \& Niemeyer 1983: 123 y Niemeyer 1985: 146).

Si bien las noticias sobre este tipo de embarcación en la documentación histórica se extienden desde mediados del siglo Xvi hasta mediados del siglo xx (fig. 12), la arqueología ha recuperado, en efecto, claras evidencias de estos pequeños navíos en sitios prehispánicos tardíos y de contacto con los inkas (Núñez, L. 1986: 20-26). ${ }^{12}$ Según L. Núñez, la evidencia arqueológica consiste en fragmentos de flotadores de cuero de lobo unidos con espinas de cactus encontrados en los sitios Bajo Molle, Caleta Huelén-23 y Caleta Vítor. El ejemplar de Vítor conserva la copuna y la tripa con que se inflaba el odre. En el manuscrito "Operación de la balsa", Niemeyer explica que la copuna es un hueso largo de ave marina, preferentemente pelícano o alcatraz, con su extremo distal incrustado en el flotador de la balsa y el proximal unido a una tripa de lobo de mar que hace de conductor del aire. El otro extremo de la víscera se amarra a una boquilla de hueso de pájaro de unos $10 \mathrm{~cm}$ de largo, con el borde biselado y suavizado, que es por donde el tripulante soplaba durante la navegación para recuperar el aire que iba perdiendo el dispositivo de flotación. ${ }^{13}$ En el mismo manuscrito Niemeyer informa que "la boquilla de la copuna es la pieza que suele encontrarse con mayor abundancia en los conchales de la época" y que en el conchal Diaguita de los pozos de Puerto Aldea recuerda haber encontrado "una buena cantidad de boquillas de hueso de pájaro". La cultura Diaguita Chilena es fechada corrientemente entre 1000 y 1535 DC.

Datos adicionales se combinan de diferente manera para respaldar en general la propuesta cronológica de Mostny y Niemeyer. Es el caso de posibles copunas en un cementerio tardío de Taltal (Mostny 1964, т. II: 46-47, Láms. s-t). También es el caso de las imágenes de balseros en petroglifos del interior del Norte Grande, consistentemente asignadas a tiempos prehispánicos tardíos (Núñez 1986: 25 y Fig. 9a-c). Núñez y Contreras (2004: 350), por su parte, reportan un fragmento de cerámica de la fase San Miguel en un conchal de Loreto, un alero rocoso situado a unos $10 \mathrm{~km}$ al norte de El Médano con representaciones de animales marinos en tintes rojizos. Por lo general, esta fase de la cultura Arica es fechada entre 900 y 1200 DC. En suma: tres evidencias indirectas refuerzan la idea de que las pinturas de El Médano datan de la primera mitad del segundo milenio de nuestra era, aunque usar a la cultura Arica como referente para el empleo de balsas de cuero de lobo resulta hoy en día menos apropiado, tanto desde el punto de vista de la distribución de los hallazgos arqueológicos de estas embarcaciones en el litoral norte, que es más amplia que la de esa cultura, como de su cronología, que parece ser más temprana.

En efecto, con posterioridad a los trabajos de Mostny y Niemeyer (1983, 1984; Niemeyer 1985) surgieron indicios arqueológicos que apuntarían a una fecha más antigua para la balsa de cuero de lobo. En el sitio Abtao-5, en la península de Mejillones, Llagostera (1990: 44) reporta restos de estas embarcaciones asociados a cerámica del tipo San Pedro Rojo Grabado. Dado que esta cerámica 
a
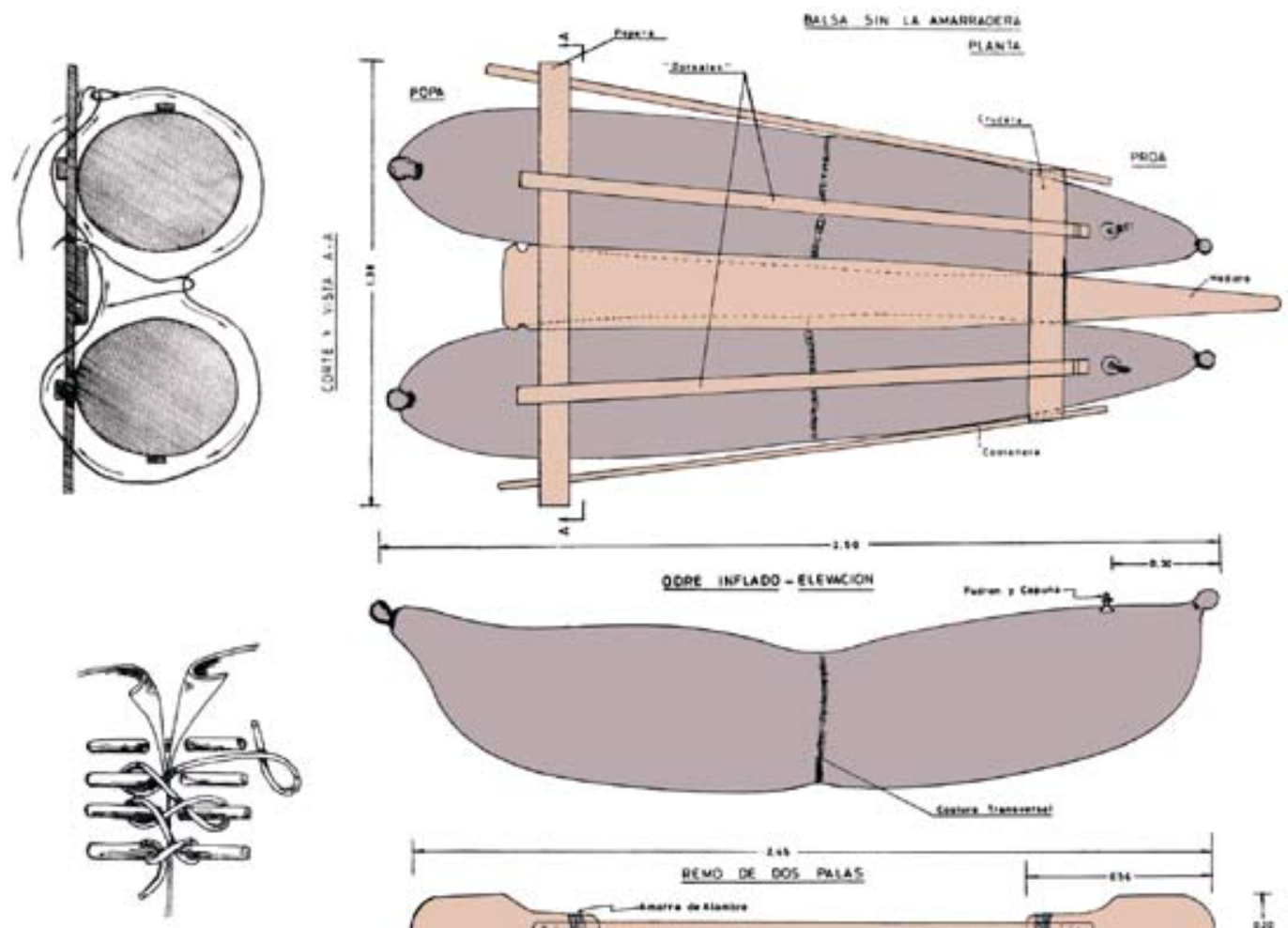

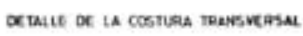
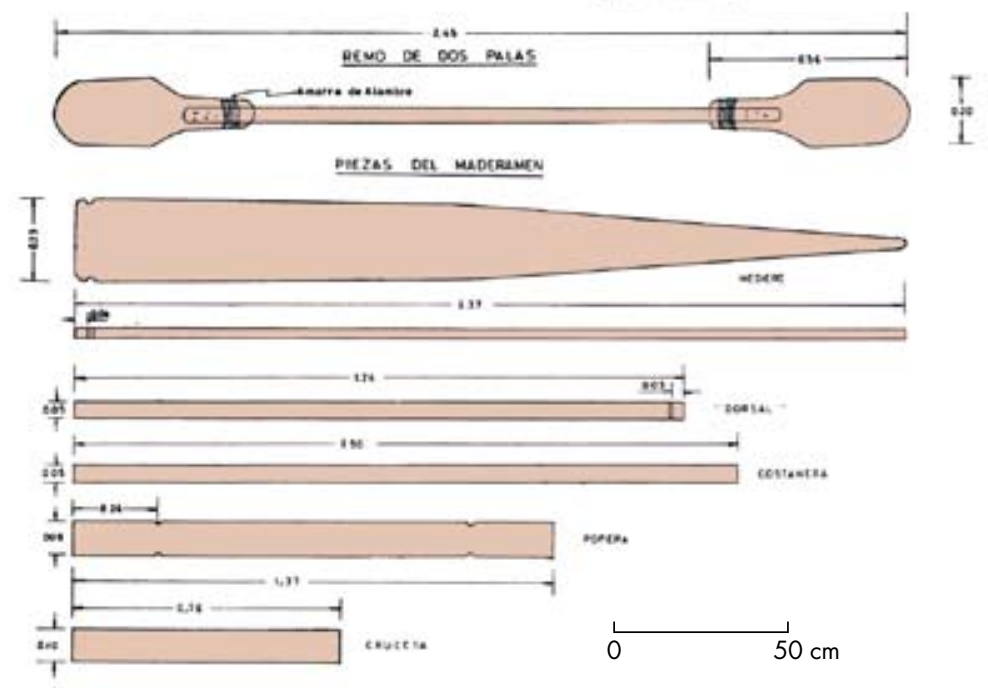

b

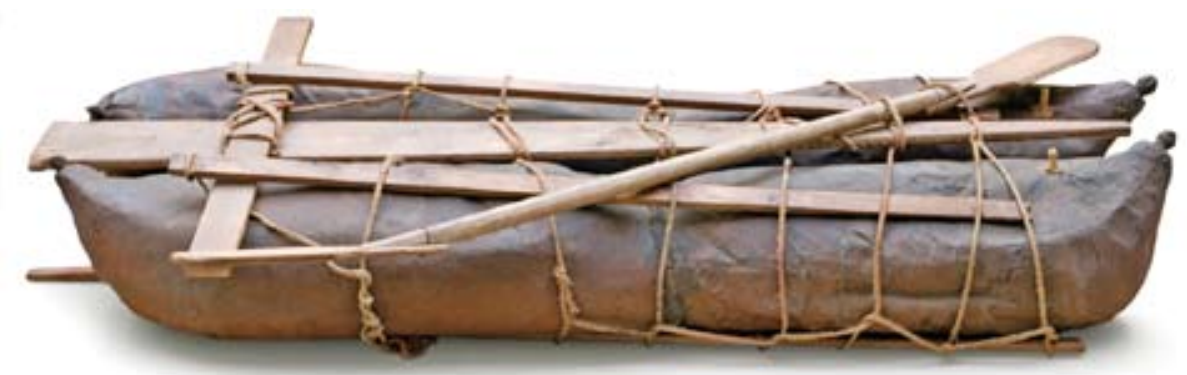

Figura 12. a) Plano de balsa de cuero de lobo (tomado de Niemeyer 1965-1966); b) balsa de cuero de lobo construida a petición de Niemeyer en Caleta Chañaral de Aceitunas, Región de Atacama (Museo Arqueológico de La Serena $\mathrm{N}^{\circ}$ 14.380, largo: 2,42 m [foto: F. Maldonado]). Figure 12. a) Plans of a sea lion skin raft (taken from Niemeyer 1965-1966); b) sea lion skin raft commissioned for Niemeyer and constructed at Caleta Chañaral de Aceitunas, Atacama Region (Museo Arqueológico de La Serena No 14.380, length: 2.42 m [photo: F. Maldonado]). 
es típica de la fase Quítor de la cultura San Pedro (de Atacama) y ésta ha sido fechada por termoluminiscencia entre 400 y 700 DC (Berenguer et al. 1986), las representaciones de estas balsas en El Médano podrían ser -en mi opinión- hasta seis siglos más antiguas que lo señalado por nuestros autores. Incluso podrían ser todavía más tempranas. El registro en cantidades significativas de congrio colorado (Genypterus chilensis) y congrio negro (Genypterus maculatus) en las basuras del sitio Punta Blanca, al sur de Tocopilla (Llagostera 1990: 44), señala un probable momento inicial para el

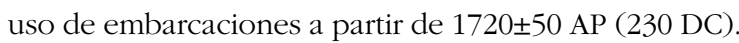
Pero la captura de estas especies de mar abierto y aguas profundas bien puede haberse hecho desde balsas de totora similares a la miniatura ofrendada hacia 215 DC en la desembocadura del río Loa (Núñez, L. 1986: 13-14) y no desde balsas de cuero de lobo. De ahí que, por el momento, sea más prudente fijar un piso cronológico tentativo situado a mediados del primer milenio para las primeras representaciones de este tipo de embarcaciones en El Médano. A medida que surjan nuevos registros de esas especies marinas en cantidades significativas en los sitios arqueológicos y/o se encuentren restos más tempranos de balsas de cuero de lobo, esta fecha extrema se irá, probablemente, profundizando. ${ }^{14}$

La evidencia "negativa", por otra parte, parece ser relevante para fijar un techo cronológico para las pinturas. No se observa en los dibujos de Niemeyer ningún panel con elementos escriturales ni representaciones de buques, figuras ecuestres u otras imágenes que sugieran situaciones de contacto con los europeos. Tampoco se conocen relatos etnohistóricos que señalen que las comunidades marítimas de la zona practicaban el arte rupestre. En consecuencia, el siglo XVI como fecha convencional de término de la actividad rupestre en la quebrada, se ajusta bien a los datos disponibles en la actualidad.

En conclusión, las pictografías de El Médano no serían anteriores a la introducción de la balsa de cuero de lobo ni posteriores al contacto europeo. Por el momento, esto las sitúa en un lapso entre los siglos v y XVI. Aquellas figuras que no involucran balsas pueden ser más tempranas, pero eso, por ahora, no pasa de ser una conjetura. ${ }^{15}$

\section{Las pinturas en el espacio ${ }^{16}$}

En cuanto a distribución geográfica, Mostny y Niemeyer (1983: 108, 1984: 87) dejan bien establecido que los motivos de fauna marina en el arte rupestre no son privativos de El Médano, sino que se hallan repartidos en otros puntos de la zona y también a través de una extensa área del litoral. Los últimos 25 años no han hecho sino confirmar estas apreciaciones.

Pinturas similares a las de El Médano, aunque más desleídas, se han encontrado en la costa de Taltal a lo largo de 130 kilómetros (fig. 13). Es el caso, entre otros, de los sitios Miguel Díaz, Punta de Plata, Loreto, Tierra del Moro, Punta Viento, Quebrada de San Ramón, Caleta Buena y Plaza de los Indios (Caiceo et al. 1985; Núñez, P. 2003; Núñez \& Contreras 2004; Rodolfo Contreras, comunicación personal 2008). Debe puntualizarse, sin embargo, que El Médano es lejos el sitio con más cantidad de paneles y mayor variedad de animales representados. Por ejemplo, Núñez y Contreras (2004: Cuadros A-D) señalan que, de un total de 34 ítems representados en ocho sitios del área de Taltal, El Médano incluye 25 ítems, seguido por Quebrada de San Ramón con 18 y, mucho más atrás, por Miguel Díaz con seis. Digamos de paso que El Médano no es el único sitio de pictografías con escenas de arrastre de cetáceos, peces, tortugas y otros animales desde balsas de cuero de lobo. Rojas Muñoz (2005) reporta "peces u otra forma marina capturada y arrastrada por embarcaciones changas de cuero de lobo" a un kilómetro de distancia de la angostura de ingreso a la quebrada de San Ramón.

Mostny y Niemeyer (1984: 5) se refieren a grabados y pictografías que reproducen especies marinas en "diferentes sitios entre la I y IV Región (al norte de Caldera [playa de Las Lizas]; en el ex puerto minero de Gatico al norte de Antofagasta; en Panul, en la costa de Coquimbo)" ${ }^{17}$ No obstante, son diferentes a las pictografías del área de Taltal. Destaca el sitio de petroglifos de Las Lizas, donde Niemeyer (1985; véase también Cervellino 1985) encontró cinco afloramientos rocosos vecinos a una aguada que contienen 146 figuras de peces (fig. 14a). Identifica tiburones, delfines, atunes y albacoras o peces espada y, en menor cantidad, posibles sardinas españolas, tollos, lenguados y palometas. Los peces son representados en forma inanimada y rara vez formando escenas. Predominan aquellos dispuestos en forma vertical, lo que, a diferencia de El Médano, llevó a Niemeyer (1985: 144-145) a interpretarlos como "peces muertos" o "fuera del agua". Aunque observa la representación de unas pocas especies de orilla, en opinión del autor se trataría en general de fauna pelágica u oceánica, cuya captura requiere del empleo de embarcaciones. Según él, la única imagen de navío y seres humanos en el sitio correspondería a una balsa de cuero de lobo tripulada por dos remeros (Niemeyer 1985: 143, Fig. 19 6-B; también Mostny \& Niemeyer 1983: Fig. 146 y Cervellino 1985: Fig. 2), sugiriendo que los petroglifos de Las Lizas tienen aproximadamente la misma edad que las pictografías de El Médano. 


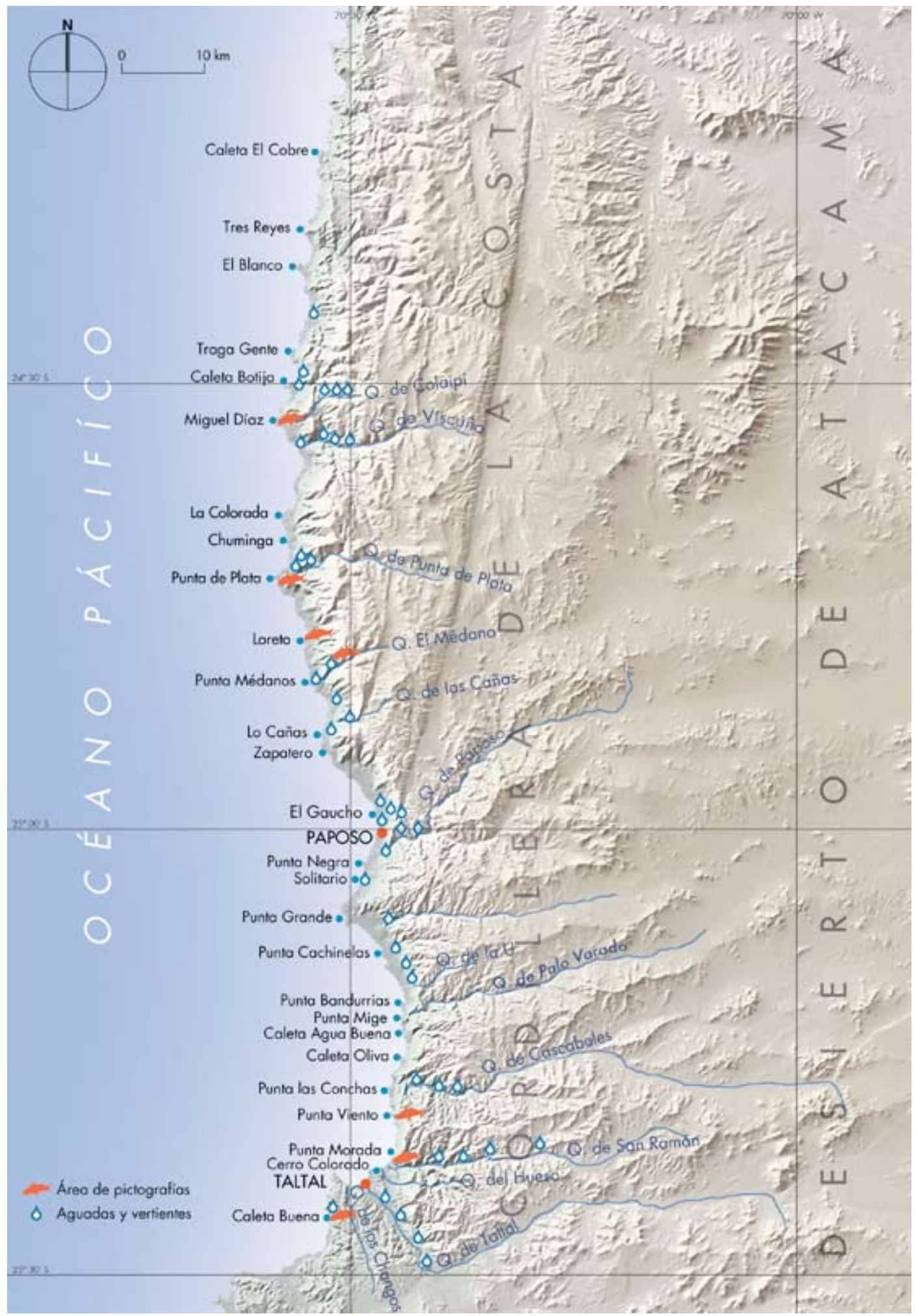

Figura 13. Mapa de la costa entre Caleta El Cobre y Taltal (adaptado de Núñez \& Contreras [2003: 18], producción: F. Maldonado sobre base topográfica cortesía del Laboratorio SIG CASEB, Pontificia Universidad Católica).

Figure 13. Map of the coast between Caleta El Cobre and Taltal (adapted from Núnez E Contreras [2003: 18], produced by F Maldonado using relief maps provided by Laboratorio SIG CASEB, POntificia Universidad Católica). 
Un bloque granítico con petroglifos muy parecidos a los de Las Lizas se encontró hace pocos años en Caleta Buena, al sur de Taltal, ahora bajo la custodia del Museo Augusto Capdeville (fig. 14b). Estaba junto a una estructura habitacional y a un "fragmento cerámico Copiapó” (Núñez \& Contreras 2004: 351, Fig. 10). Como se trata del mismo litoral donde prevalecen las pictografías de Estilo El Médano, en ese sector del litoral aparecen entreverados dos distintos estilos de arte rupestre. Si efectivamente El Médano y Las Lizas son estilos contemporáneos entre sí, asunto cuya
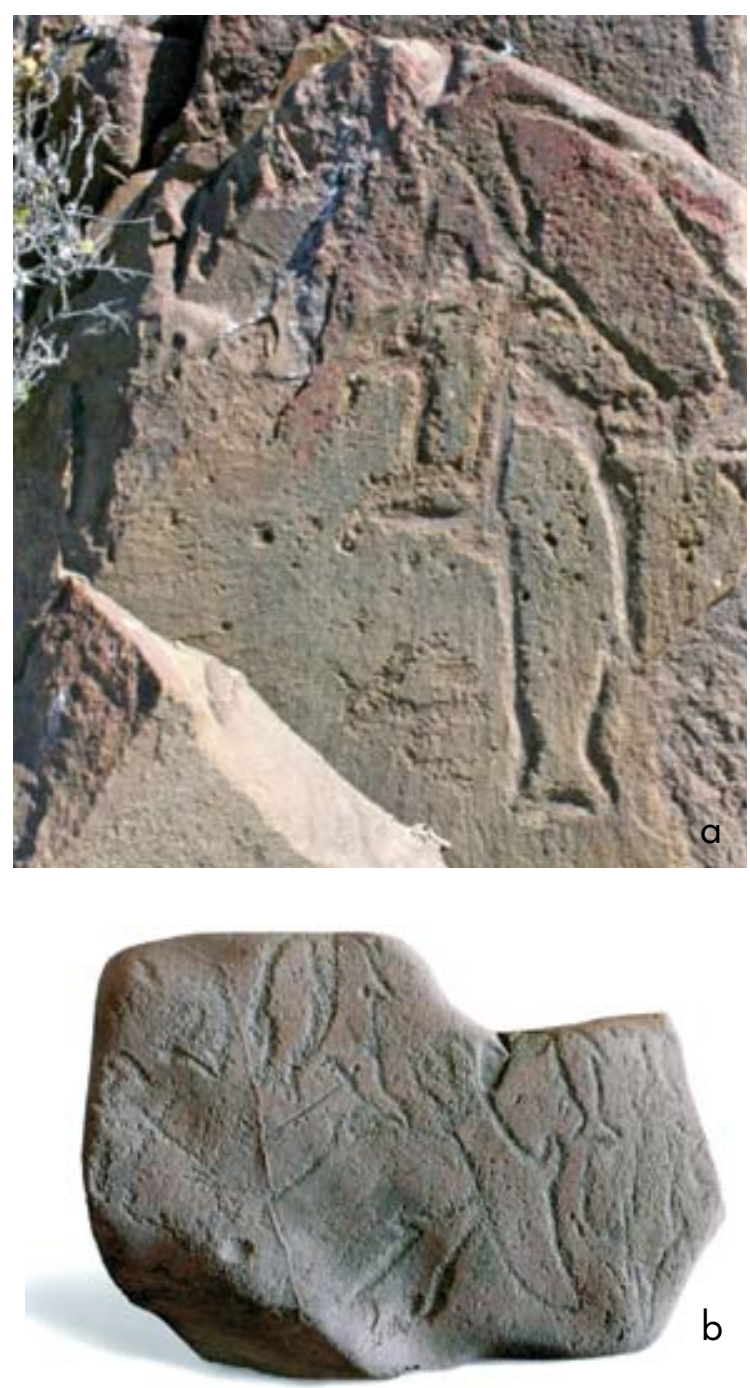

Figura 14. Petroglifos: a) Panel del yacimiento de petroglifos Las Lizas, Región de Atacama (foto: F. Gallardo); b) Bloque con petroglifos encontrado en Caleta Buena, Taltal, largo: $95 \mathrm{~cm}$ (foto: L. Cornejo).

Figure 14. Petroglyphs: a) Panel of petroglyph site at Las Lizas, Atacama Region (photo: F. Gallardo); b) Stone with petroglyphs identified at Caleta Buena, Taltal, length: $95 \mathrm{~cm}$ (photo: L. Cornejo). comprobación está pendiente, resulta tentador conferir a estos traslapes estilísticos alguna connotación interétnica o intercultural, aunque bien podría ser que un mismo grupo étnico o cultural se haya expresado a través de diferentes estilos de arte rupestre, por ejemplo, conforme a las características particulares de cada lugar.

Los antes citados petroglifos de peces de Gatico también guardan similitudes formales con los de Las Lizas (Niemeyer 1985: 144), cuestión que extendería la zona de traslape estilístico a más de $400 \mathrm{~km}$ de litoral. El caso de Panul, en cambio, parece ser diferente. Se trata de un bloque aislado cercano a la orilla del mar con una pictografía en rojo de una ballena y un personaje antropomorfo (Gonzalo Ampuero, comunicación personal 2008). No conocemos esta pictografía como para establecer si califica como una proyección meridional del Estilo El Médano y, por lo tanto, como una expresión más del mencionado traslape. Otro tanto ocurre con la pictografía de balsa del sitio Finca de Chañaral, a unos $15 \mathrm{~km}$ al norte de Inca de Oro y con las pictografías de peces de Caleta Flamenco, al norte de playa de Las Lizas, reportadas por Cervellino (1985: 356, 358, Tabla 2). En todo caso, distancias de navegación como las que separan a Las Lizas de Gatico o a El Médano de Panul, estaban, al parecer, dentro del radio de acción de los balseros (Llagostera 1990: 38; véase también Contreras \& Núñez 2009: 95).

\section{IDENTIFICACIÓN DE LAS IMÁGENES}

Entre Caleta El Cobre y Taltal, la línea de costa está formada por una sucesión de puntas o salientes rocosas que se proyectan en el océano, dejando entre ellas grandes y pequeñas escotaduras de mar en forma de arco a las que ingresa una gran diversidad de especies. ${ }^{18}$ Estas escotaduras parecen haber sido uno de los principales teatros de operación de los grupos costeros y, aparentemente, fueron el foco de atención de los pintores de El Médano. Es obvio que éstos fueron buenos observadores del mundo marino que tenían frente a sus ojos y hábiles en trasladar la forma de los animales desde la naturaleza a la piedra. Como predadores que observan de manera incesante a sus presas, deben haberlas identificado automáticamente desde la distancia, merced al perfil característico de sus siluetas; los ejemplares muertos y las prácticas de faenado, en tanto, pueden haber contribuido también a un preciso conocimiento de sus detalles anatómicos (Clottes 1989). De ahí que las figuras generalmente muestren un alto grado de isomorfismo con relación a las características 
de los referentes en la realidad primaria. Tanto, que a veces conducen a Mostny y Niemeyer (1984) a pronunciarse sobre la identificación de algunos animales en el nivel de orden o de familia zoológica, y en ocasiones, incluso en el nivel de género o de especie:

\begin{abstract}
Las especies discernibles, aparte de una multitud de peces imposibles de identificar, son cetáceos, especialmente el calderón negro, el cachalote y la ballena; el lobo de mar, el pez espada o albacora; el pez martillo y la tortuga. Una de ellas representa a la llamada tortuga laúd (Dermochelys coriacea), propia de los océanos tropicales y visitante ocasional de las costas de América (Mostny \& Niemeyer 1984: 3; véase también Mostny \& Niemeyer 1983: 47).
\end{abstract}

Estos pronunciamientos corresponden al nivel mínimo de significación: el de la denotación del mensaje icónico, que es el que permite al especialista "trasponer la información del lenguaje visual al lenguaje verbal por el simple recurso de nombrar los objetos representados y precisar eventualmente sus relaciones espaciales" (Colle 1998: 168). Debe considerarse, empero, que en El Médano la denotación en estos términos no siempre es obvia.

\section{Problemas de identificación}

Los autores informan que la identificación de animales fue hecha con la ayuda de especialistas en fauna (Mostny \& Niemeyer 1983: 106), colaboración interdisciplinaria que fue muy propia de Niemeyer (p. e., véase 1985: 137-141, 169-171). Así lo confirma el manuscrito "Prólogo", donde Niemeyer agradece por esta colaboración al médico Alfredo Cea, de larga experiencia en trabajos de mar, a los biólogos marinos del Museo Nacional de Historia Natural Nibaldo Bahamondes, Pedro Báez y Roberto Meléndez, y al zoólogo José Yáñez de la misma institución. Niemeyer -es preciso señalarlo- se tomó mucho tiempo en estas identificaciones y por lo que dice en dicho "Prólogo", es presumible que las postergaciones que sufriera la monografía que planeaba publicar obedecieran en parte a lo trabajoso de este tipo de pericias, donde, en muchos casos, es de suyo difícil llegar a identificaciones certeras sobre la base del examen de imágenes rupestres. ${ }^{19}$ Existe un manuscrito, titulado "Los peces (colaboración del Dr. Alfredo Cea E.)", cuyas observaciones acerca de las posibles especies marinas representadas en El Médano revelan las dificultades de la tarea. En algunos casos, Cea se basa en las características intrínsecas del animal, es decir, en consideraciones estrictamente anatómicas de la figura (forma del cuerpo; forma, distribución de aletas y apéndice caudal); en otras, en criterios extrínsecos, esto es, en las técnicas y maniobras de captura del animal (arponeo, pesca con sedal, arrastre desde las balsas, etc.) (fig. 15a), y, en ciertas oportunidades, en ambos criterios a la vez. ${ }^{20}$

Si bien Mostny y Niemeyer (1983: 50; 1984: 4) definen a El Médano como un arte rupestre "naturalista", están conscientes de que las figuras no son reproducciones fieles de sus referentes en el mundo marino o terrestre, al punto que en otros pasajes dudan si calificarlas como naturalistas, seminaturalistas o esquemáticas (Mostny \& Niemeyer 1983: 106; 1984: 5). En verdad, las “imágenes son siempre modelos de realidad, independiente del nivel de realidad que aquéllas posean" (Villafañe \& Mínguez 2000: 25) y las pinturas de El Médano no son una excepción. Éstas se realizan con perfecta continuidad del contorno y cierre de la forma, pero el resultado son simples siluetas, lo que supone un fuerte grado de simplificación y reducción de las características formales de los animales. ${ }^{21}$ Las dificultades para la identificación de especies son más evidentes cuando Cea nota supresión de rasgos, incorporación de atributos ajenos a una especie, incluso simplificaciones extremas, que tornan incierta o sencillamente imposible la correcta identificación (fig. 15b, derecha arriba).

¿A qué obedecen estas transformaciones que alteran las características naturales de los animales? Dejando de lado una supuesta impericia, una respuesta lógica sería que, puesto que las pinturas eran plasmadas a considerable distancia del mar, no había posibilidad de pintar las criaturas marinas mirando los especímenes reales, como quien pinta un cuadro con un modelo a la vista. Salvo un dudoso y descontextualizado hueso grabado encontrado cerca de Chañaral (Rojas Muñoz 2005), no se ha hallado nada parecido a bocetos en soportes portátiles que pudieran facilitar esta operación. Más probable es que los pintores empleasen primero la información que reunían a partir de un número de "instantáneas" captadas por observación (Villafañe \& Mínguez 2000: 160), "transportasen" luego esas imágenes en la mente y por último las reprodujesen de memoria en la quebrada, lo que deja harto espacio para que se produzcan alteraciones. La lógica, empero, nunca garantiza la validez de un argumento. Es también posible que estas transformaciones hayan obedecido al propósito de los pintores de no representar siempre animales reales. Que en ocasiones buscasen de modo deliberado cierta ambigüedad, combinando atributos de diferentes especies o creando formas limítrofes entre dos o más de ellas. Los mitos e imaginarios documentados por la etnografía y el folklore están llenos de casos a través del mundo de seres con características mixtas. Sea como fuese, convengamos en que no se puede pretender que formas nativas de categorizar y representar visualmente la fauna, deban coincidir necesariamente con las taxonomías científicas. ${ }^{22}$ 

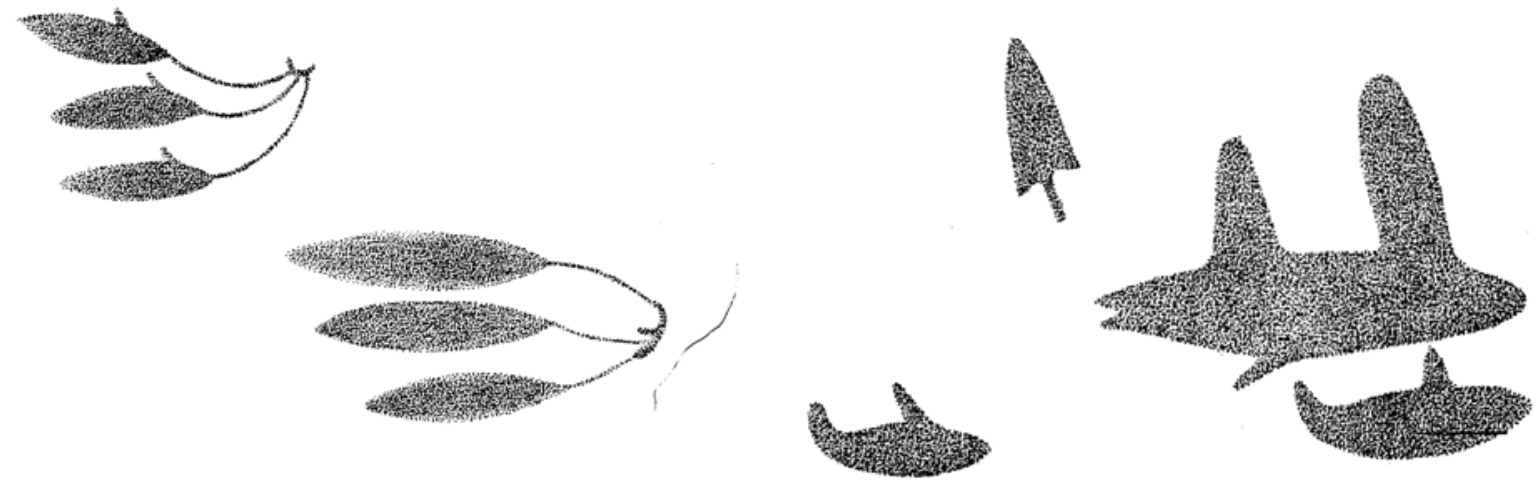

Figura 15. a) Pesca de línea (detalle de panel 29- $\tilde{\mathrm{N}}-7$ ); b) al centro, representación de especie marina sin equivalente en la naturaleza (panel 29--̃̃-6).

Figure 15. a) Line fishing (detail of panel 29-N-7); b) in the center, an image of a marine species not found in nature (panel 29-N-6).

\section{Motivos problemáticos}

Uno de los motivos para los que Mostny y Niemeyer (1983: 50; 1984: 4) declaran carecer de interpretación cierta, son unas figuras triangulares que aparecen aisladas, en pares o en tríos en la quebrada (fig. 16a-c). Los autores sugieren con mucha cautela y algo de distancia que podría tratarse de aletas dorsales de tiburón. En otra publicación, Niemeyer (1985: 144) añade que también podrían ser aletas de delfín, aunque bien podría tratarse de aletas de varias otras especies (fig. 16d). Lautaro Núñez (comunicación personal 2007), por ejemplo, asocia estos motivos con la aleta de la albacora o pez espada. Este pez es una especie pelágica que en verano se acerca a la costa, en donde suele vérsele nadando con la aleta dorsal fuera del agua. Núñez dice que los actuales "albacoreros" de la región llaman a estas aletas "capachos" (véase también Van Kessel 1986) y que sienten una verdadera obsesión por ellas. Añade que por la forma de este apéndice los pescadores saben de qué animal se trata y cuál es su tamaño. Esta actividad de avistamiento es denominada por ellos "salir a capachear".

El dato de L. Núñez es interesante, ya que estos avistamientos pueden haber formado parte de las prácticas de los antiguos pescadores/cazadores de la zona y haber sido plasmados de esa forma en el arte rupestre de El Médano. Pero también lo es porque sugiere ciertas operaciones gráficas hechas por los pintores. No únicamente estilizaban las figuras, al parecer recurrían también a procedimientos más complejos, como tomar un signo por la cosa significada. Una suerte de abreviación o sinécdoque, porque la aleta implicaría el animal, incluso aunque éste no se muestre completamente. Hay que decir, sin embargo, que, hasta donde he podido comprobarlo a través de los dibujos de Niemeyer, este recurso retórico no parece haberse aplicado a otras representaciones rupestres de la quebrada. Por lo demás, los dibujos de Niemeyer muestran también representaciones completas de albacoras (fig. 17a, b).

Otro motivo problemático es aquel que en el manuscrito "Los peces" Cea describe como "la exageración de la curva de la cola que se transforma en un asa unida al dorso". Son exageraciones que trascienden los límites de probabilidad anatómica de la mayoría de las especies. Cea sugiere que podría tratarse de sélacos, particularmente tollos, ya que son los "únicos peces capaces de esa flexión extrema de su extremidad caudal" (fig. 18a). Algunos pescadores de Taltal, sin embargo, piensan que son congrios, dado que estos peces efectúan pronunciadas contorsiones del cuerpo (Rodolfo Contreras, comunicación personal 2008). No obstante, la forma voluminosa y redondeada de algunas de estas figuras -rechoncha, para usar la expresión de Cea- las asemeja más a algunos cetáceos (fig. 18b [izquierda abajo] y c). De allí que otra posibilidad es que se trate de representaciones de ballenas lanzando agua y aire por sus aventadores. Desde estos orificios dorsales estos mamíferos marinos expulsan columnas de agua vaporizada que alcanzan varios metros de altura. Es cierto que la curva semeja a veces un asa unida al dorso del animal, pero algunos casos en que esta unión no se verifica prestan algún respaldo a esta posibilidad. Procesos convencionales de simplificación de la figura, corrupciones del motivo original o deformaciones producidas por el ángulo de visión elegido por el artista, podrían estar detrás de este enigmático motivo. Digamos, en todo caso, que concedemos una baja probabilidad a esta interpretación.

Un tercer motivo complicado son los "enrejados" o reticulados en forma de óvalo o de trapecio (fig. 19a). Nuestros autores interpretan estas grillas como 
a
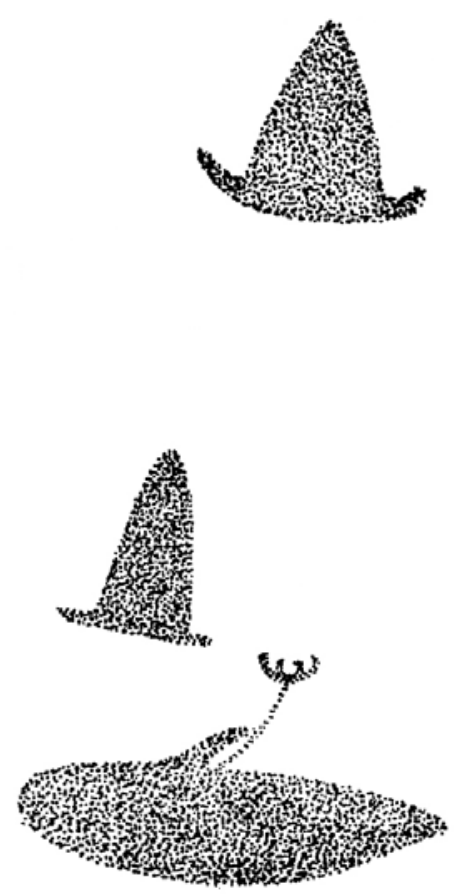

0

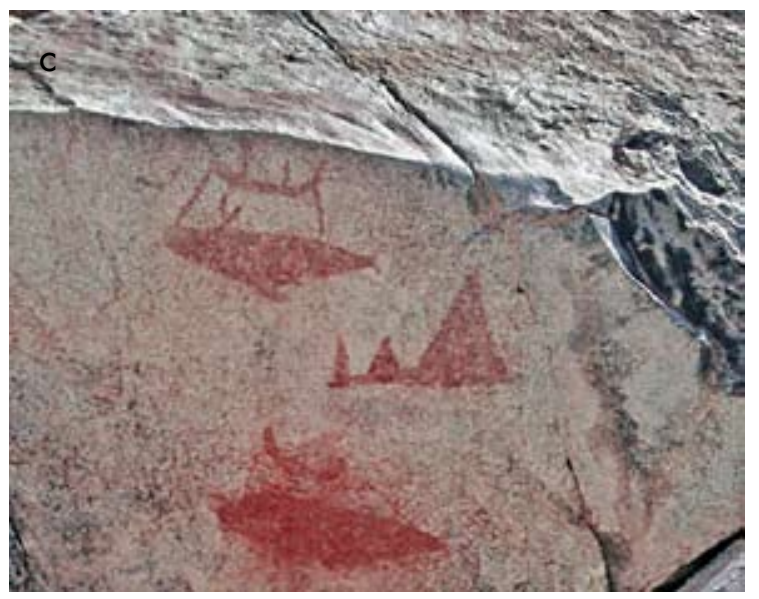

b
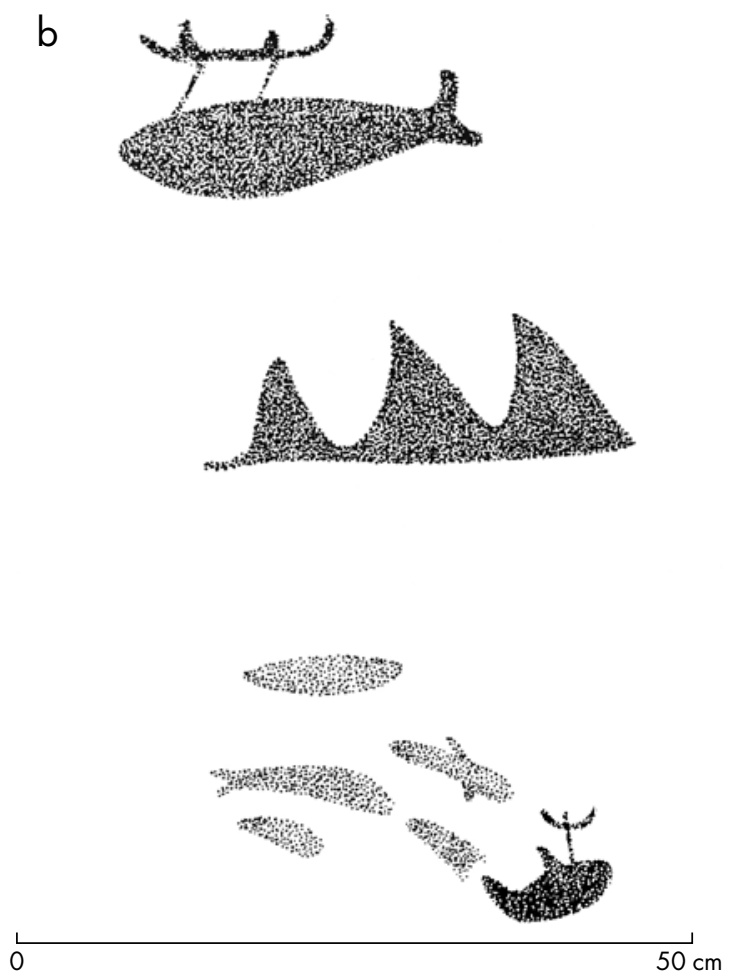

Figura 16. a) Elementos triangulares aislados (panel 10-A; b) triangulares en trío (panel 16-B); c) pictografía con trío de elementos triangulares (panel 29-E) (foto: F. Maldonado); d) Aleta de orca.

Figure 16. a) Isolated triangular elements (panel 10-A; b) trio of triangular elements (panel 16-B); c) pictograph with trio of triangular elements (panel 29-E) (photo: F. Maldonado); d) Orca fin.

"chinguillos o cestos para las faenas de pesca" (Mostny \& Niemeyer 1983: Fig. 149, 1984: 86-87, Fig. 4). Con posterioridad, Niemeyer (1989b: 2) hace notar que esta interpretación coincide con los dibujos de un artículo de Quiroz (1989) sobre la pesca con canastos entre los yámanas del Canal Beagle, en el extremo sur de Chile: "Calza bien -aduce- por tratarse en ambos casos de culturas esencialmente de economía marítima".

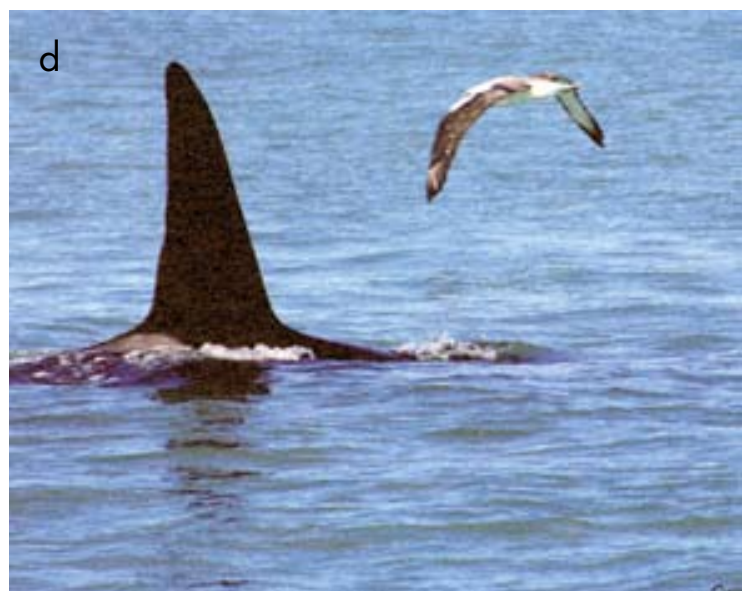

Más allá del paralelo etnográfico que propone, subyace en Niemeyer una cierta seguridad a priori en su interpretación, acaso porque abriga la íntima convicción de que el arte rupestre de El Médano no es abstracto, sino figurativo. Se ha formado la opinión de que los códigos visuales de estas pictografías permiten identificar los referentes reales. Sin embargo, no conozco datos de que, al igual que los canoeros fueguinos, los balseros 

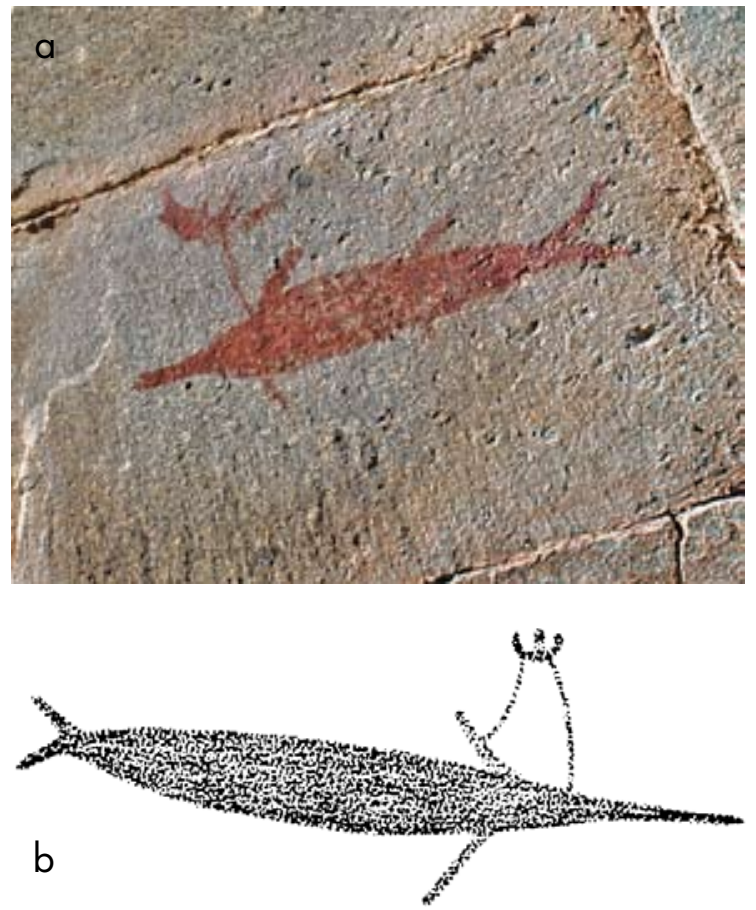

Figura 17. Albacora: a) detalle en panel 41 (foto: F. Maldonado); b) detalle (panel 29- $\tilde{\mathrm{N}}-3$ ).

Figure 17. Swordfish: a) detail of panel 41 (photo: F. Maldonado); b) panel detail (panel 29-N-3).

nortinos hayan prendido una pértiga a sus canastos y arrastrado el implemento por el agua para capturar peces mientras navegaban en sus embarcaciones. Personalmente, me inclino por la opinión de Capdeville (2008 [1923]: 31) de que eran representaciones simplificadas de redes de pesca. Sobre todo al observar el dibujo de la figura $19 \mathrm{~b}$, en el que hay un pez y un reticulado trapezoidal yuxtapuestos en una unión vinculada. El pez pareciera arrancar o escabullirse de la red con que se intenta atraparlo. Por otra parte, Niemeyer (1989b) admite no haber encontrado equivalentes etnográficos para los diseños reticulares de forma rectangular, que denomina "parrillas" (fig. 19c), pero es dudoso que éstos y los reticulados en forma de óvalo o de trapecio correspondan a referentes distintos. Pienso que la variación entre estas formas geométricas obedecería a diferentes visuales escogidas por los pintores para representar el mismo artefacto. De hecho, todos estos reticulados, incluso más en el caso de los rectangulares, parecen estar flotando en el agua a modo de redes de pescar.

Pese al figurativismo que domina el arte rupestre de El Médano, se observan otros casos difíciles de descifrar. Me refiero tanto a ciertos elementos fusiformes barbados, como a elementos parecidos a letras "E" vueltas hacia arriba (fig. 20). Los primeros podrían ser arpones o instrumentos con garfios para capturar peces y cefalópodos (véase Berenguer 2008b: 25), cuyo hallazgo ha sido reportado en los cementerios de Taltal. Los segundos dan la impresión de ser esquemáticas representaciones de balsas de cuero de lobo. Si bien en la inmensa mayoría de los casos las embarcaciones son perfectamente identificables por su forma de medialuna, en estos raros ejemplos son poco reconocibles.

\section{Balsas y presas}

Los autores enfatizan que la "balsa y sus tripulantes son extraordinariamente pequeños, a veces irreconocibles al lado del animal", como queriendo minimizar al hombre y su embarcación (Mostny \& Niemeyer 1984: 3). Sostienen que esta desproporción de tamaño es inverosímil (Mostny \& Niemeyer 1984: 4), dado que la captura de especies de ese volumen los habría hecho naufragar (Mostny \& Niemeyer 1983: 107). Se deduce, entonces, que habría una manipulación forzada de las proporciones por parte del pintor, una deliberada distorsión de escala. Los autores proponen que se trata "de una relación simbólica que pretende ante todo llamar la atención al gran éxito obtenido en la faena" (Mostny \& Niemeyer 1983: 107, 1984: 87). Y la verdad es que debido a la configuración de las escenas, las masivas figuras de las presas capturadas funcionan casi siempre en la composición como "atractoras" de la vista, determinando claramente la secuencia de la exploración visual: el contraste de tamaño focaliza primero la atención en la ballena (u otra presa de gran tamaño) y luego la dirige hacia los autores de la captura y sus minúsculas embarcaciones (fig. 21). ${ }^{24}$

Esta tesis del empequeñecimiento-que-agrandala-hazaña, es atractiva, porque coloca el centro de la interpretación en el resultado de la acción: la caza exitosa de grandes animales. Sin descartarla del todo (las escenas de cazadores enfrentando guanacos exhiben en ocasiones una similar distorsión de escala entre sus componentes), es posible proponer una explicación alternativa basada en ciertas relaciones espaciales entre las figuras, particularmente en términos de distancia y profundidad. Mientras las balsas de cuero de lobo que se conocen a través de la iconografía histórica parecen haber tenido entre 2 y $6 \mathrm{~m}$ de eslora, especies como la ballena jorobada alcanzan longitudes de 15 a $17 \mathrm{~m}$, la orca 7 a $8 \mathrm{~m}$, el cachalote común 11 a $18 \mathrm{~m}$ y la albacora poco más de $4 \mathrm{~m}$. Si a esto agregamos que, salvo muy contadas excepciones, las presas capturadas se hallan en primer plano, con las balsas atrás (fig. 21) o en uno de sus costados (fig. 23, derecha abajo), las desproporciones de tamaño resultan verosímiles. La 
a
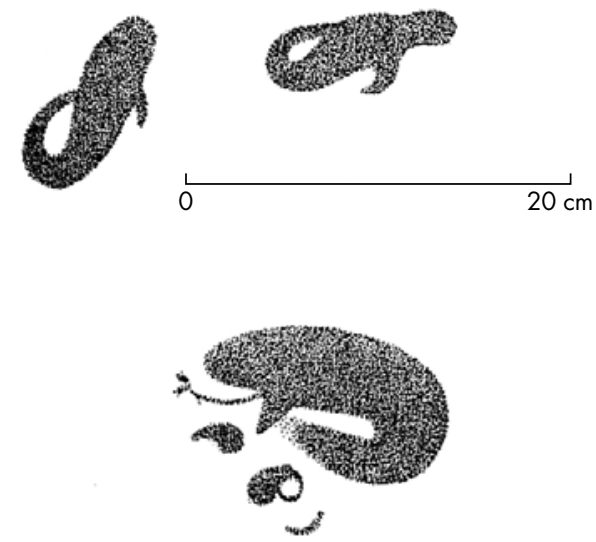

$$
\text { o }
$$

$20 \mathrm{~cm}$

b

C

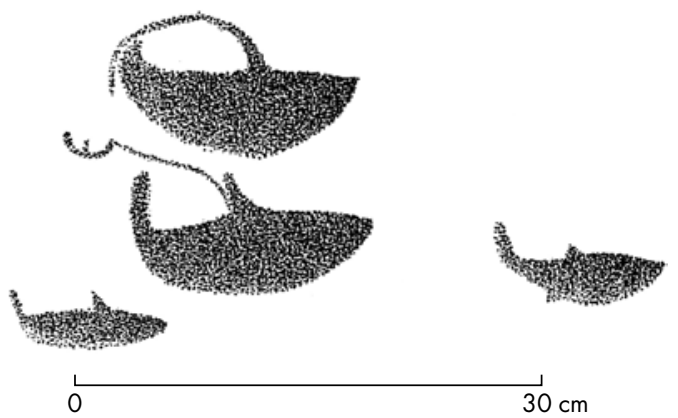

Figura 18. Exageración de la curva de la cola: a) paneles 29-Ñ-3 y 29-Ñ-4; b) panel 33-A; c) panel 33-B.

Figure 18. Exaggerated curve of the tail: a) panels 29- $\tilde{N}-3$ and 29$\tilde{N}-4$; b) panel 33-A; c) panel 33-B. a
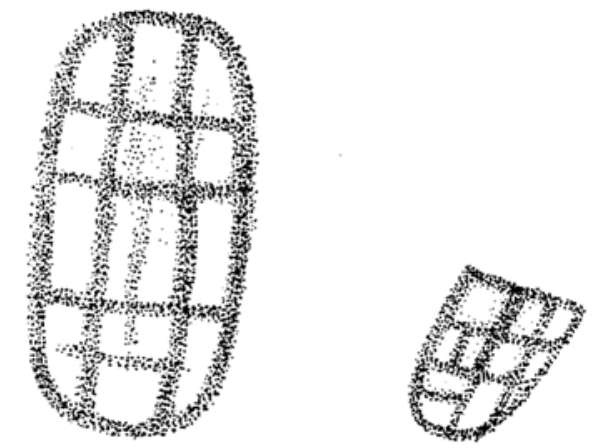

ᄂ

$50 \mathrm{~cm}$

b

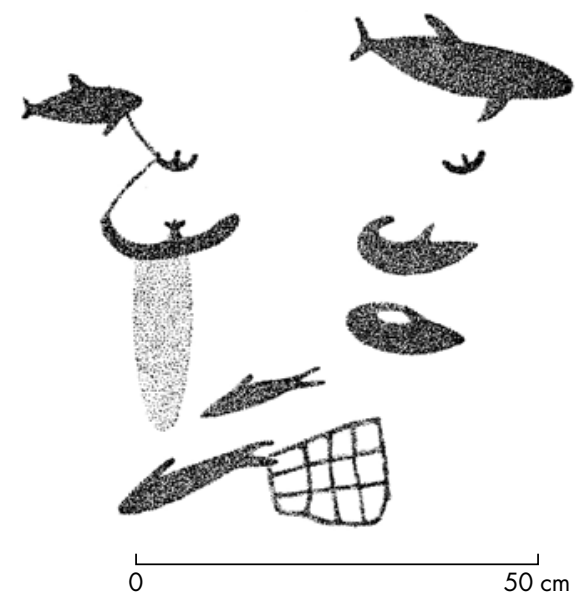

C

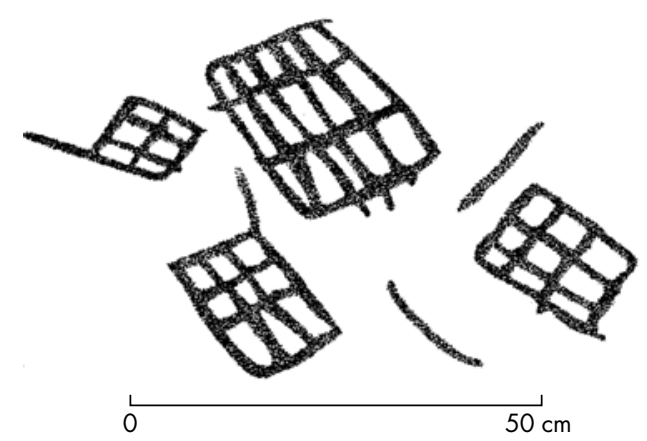

Figura 19. Reticulados: a) panel 29-F; b) panel 46; c) panel 23. Figure 19. Grids: a) panel 29-F; b) panel 46; c) panel 23. 


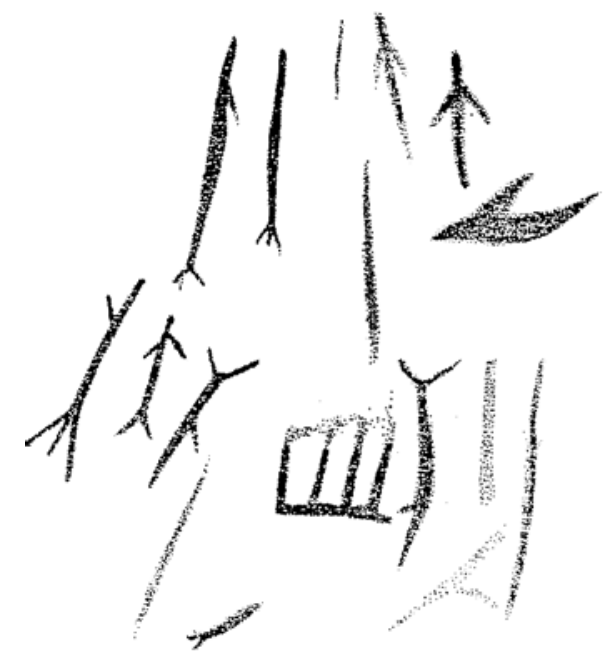

Figura 20. Diseños esquemáticos (panel 24).

Figure 20. Schematic designs (panel 24).

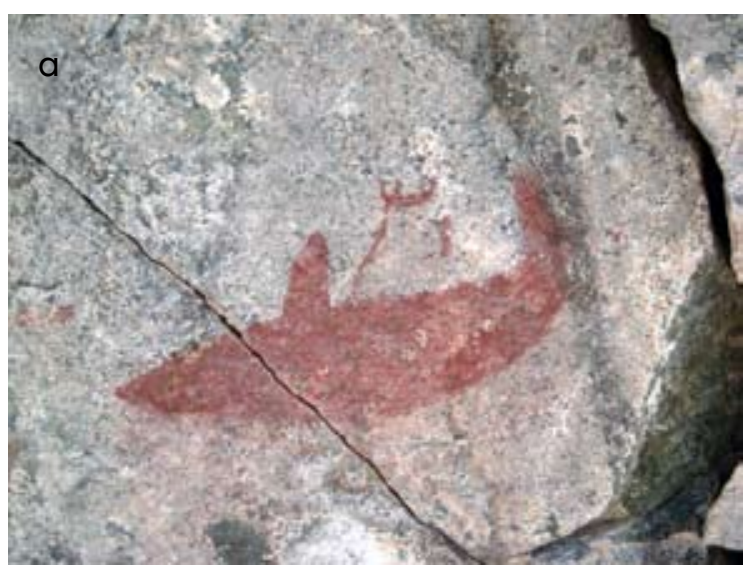

Figura 21. a) panel 32-A (o C); b) panel 2 (fotos: J. Berenguer). Figure 21. a) panel 32-A (or C); b) panel 2 (photos: J. Berenguer).

influencia de los planos de las figuras sobre las diferencias de tamaño es más clara en las balsas que arrastran tortugas laúd ( $2 \mathrm{~m}$ de largo y hasta $2,70 \mathrm{~m}$ entre ambas aletas delanteras): mientras en el panel 20-D balsa y tortuga se encuentran en el mismo plano y hay menos desproporción de tamaño (fig. 5a), en los paneles 34-A y 34-B la tortuga está en primer plano y es mucho más grande que la balsa que se halla detrás. Lo mismo sucede con la pictografía descrita por Mostny y Niemeyer (1983: Fig. 147) como "Escena de captura de una tortuga", cuya fotocopia se encuentra extraviada (fig. 22).
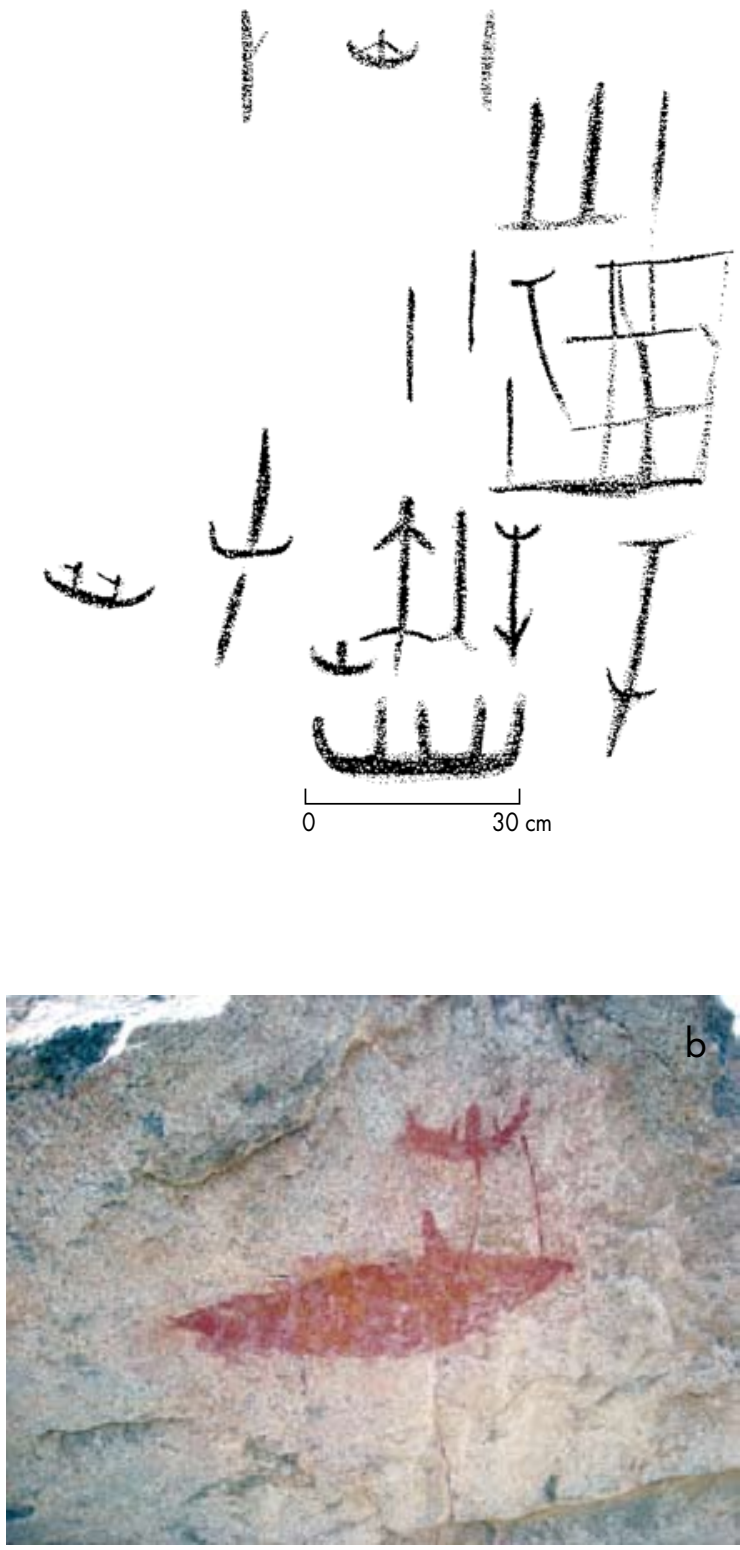

Reconozco mi reticencia a hablar en estos casos de perspectiva, por la "carga académica" que esta técnica visual tiene en la historia del arte de Occidente (también dudo en hablar de escorzo, aunque algunos casos parecieran bordear esta posibilidad [véase fig. 23]). No obstante, mantengo la impresión de que los pintores de El Médano se dieron el trabajo de acomodar el tamaño y la posición de balsas y presas para crear la ilusión de distancia y profundidad. Algo así como "una restitución de la tercera dimensión en la representación icónica del espacio" (Villafañe \& Mínguez 2000: 42), en donde lo 


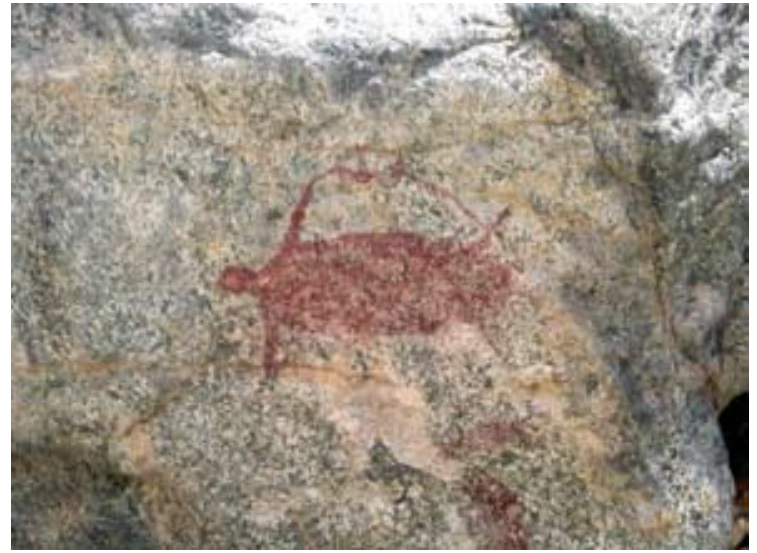

Figura 22. Balsa remolcando tortuga laúd (foto: J. Berenguer). Figure 22. Raft towing a leatherback turtle (photo: J. Berenguer).

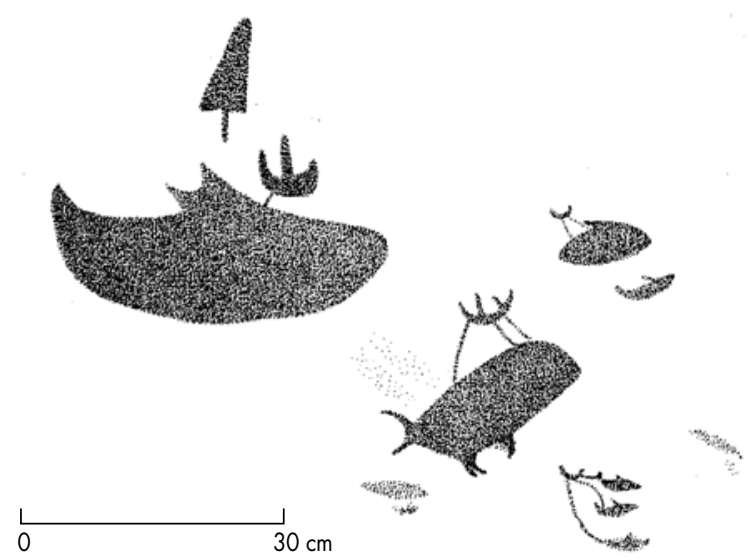

Figura 23. Al centro abajo, posible uso de escorzo (panel 29- $\tilde{\mathrm{N}}_{1}$ ). Figure 23. Lower center, possible use of foreshortening (panel 29- $\left.\tilde{N}_{1}\right)$.

que es más pequeño no sólo lo es por ser tal en la realidad, sino también por encontrarse más alejado. Existe, en consecuencia, cierta verosimilitud en las escenas de balsas y presas, a primera vista tan desproporcionadas. Por lo demás, la cacería de grandes cetáceos como la ballena está documentada para los grupos costeros de inicios del siglo XVII en las costas del norte de Chile, como veremos a continuación.

\section{El arte rupestre como relato}

Mostny y Niemeyer fueron exponentes en nuestro medio de lo que Lewis-Williams (2000) ha denominado una aproximación narrativa al arte rupestre. Eso por lo menos se desprende cuando tocan el asunto de las escenas en términos generales (Mostny \& Niemeyer 1983: 126) y, más específicamente, cuando aluden a ellas refiriéndose a El Médano y a otros estilos:

Las escenas narrativas se dirigen a grupos más grandes y conmemoran algún evento único en el cual ha participado toda la comunidad. En este sentido tienen un poder aglutinante y refuerzan el sentimiento de unidad clánica o tribal. No cabe duda que estos sucesos fueron larga y gustosamente discutidos y comentados por los participantes, narrados a las generaciones nuevas, ingresando finalmente a la tradición histórica del grupo (Mostny \& Niemeyer 1983: 126).

Consistente con esta aproximación, cada representación "relataba" diferentes eventos, con lo cual las imágenes celebraban la memoria de pescas y cazas excepcionalmente exitosas (Mostny \& Niemeyer (183: 116) llevadas a cabo por el grupo en momentos específicos o particulares (fig. 24). ${ }^{25}$

Para nuestros autores, las escenas de arte rupestre de El Médano "están dispuestas en unidades narrativas" (Mostny \& Niemeyer 1983: 115): "Desde embarcaciones tripuladas -dicen- se ha logrado arponear peces y mamíferos marinos, quedando la cabeza del arpón y el terminal de la correa en manos de los pescadores" (Mostny \& Niemeyer 1983: 116). Y la verdad es que la cita textual que ellos publican sobre los changos históricos contribuye mucho a interpretar estas pictografías en clave de relato:

Todos los indios de esta Costa [de la Región de Antofagasta], demás del sustento referido [congrios, tollos, lisas, dorados, armados vagres, jureles, atunes, pulpos y otros muchos géneros de pescados], que tienen de marisco, su principal comida y bebida, es azeite de vallena, para lo cual matan muchas de que ay cantidad en aquella costa; el modo de pescarlas, o matarlas, es curioso, y sagas. Ay en aquella provincia cantidad de cobre, del qual hazen vnas puas, o Garrochuelas menores, que garrochones, estos los ponen en vnas hasta pequeñas de tal suerte dispuestas, y atadas con vn latigo de cuero de lobo a la muñeca, van a tirar a las vallenas: las quales de ordinario en aquella costa duermen de medio dia para arriba, dos, o tres oras con gran reposo, y profundo sueño, sobre aguadas, y con vna ala pequeña, que tienen sobre el coraçon se cubren la caueça para dormir por el sol. Entonces que la a asechado el indio quando duerme, en que esta diestro, llega en su valsilla de lobo, en que va para valerse de ella sin que la pueda perder, y se llega donde la vallena duerme: y le da vn harponaso deuaxo del ala, donde tiene el coracon, y instantáneamente se dexa caer al agua, por escaparse del golpe de la vallena; que en viéndose herida se embrabece dando grandes bramidos, y golpes en el agua, que la arroja muy alta con la furia, y colera que le causa el dolor, y luego tira bramando hazia la mar, hasta que se siente cansada, y mortal; en el interin el indio buelue a cobrar su valsilla, y se viene a tierra a ojear y atalayar adonde viene a morir a la costa, y así están en sentinela, hasta que la ven parar (Vásquez de Espinosa 1948 [1628-1629]: 618-619).

Dada esta descripción, no puede sorprender que en las interpretaciones de Mostny y Niemeyer subyazca la idea de una continuidad cultural muy directa entre ese 


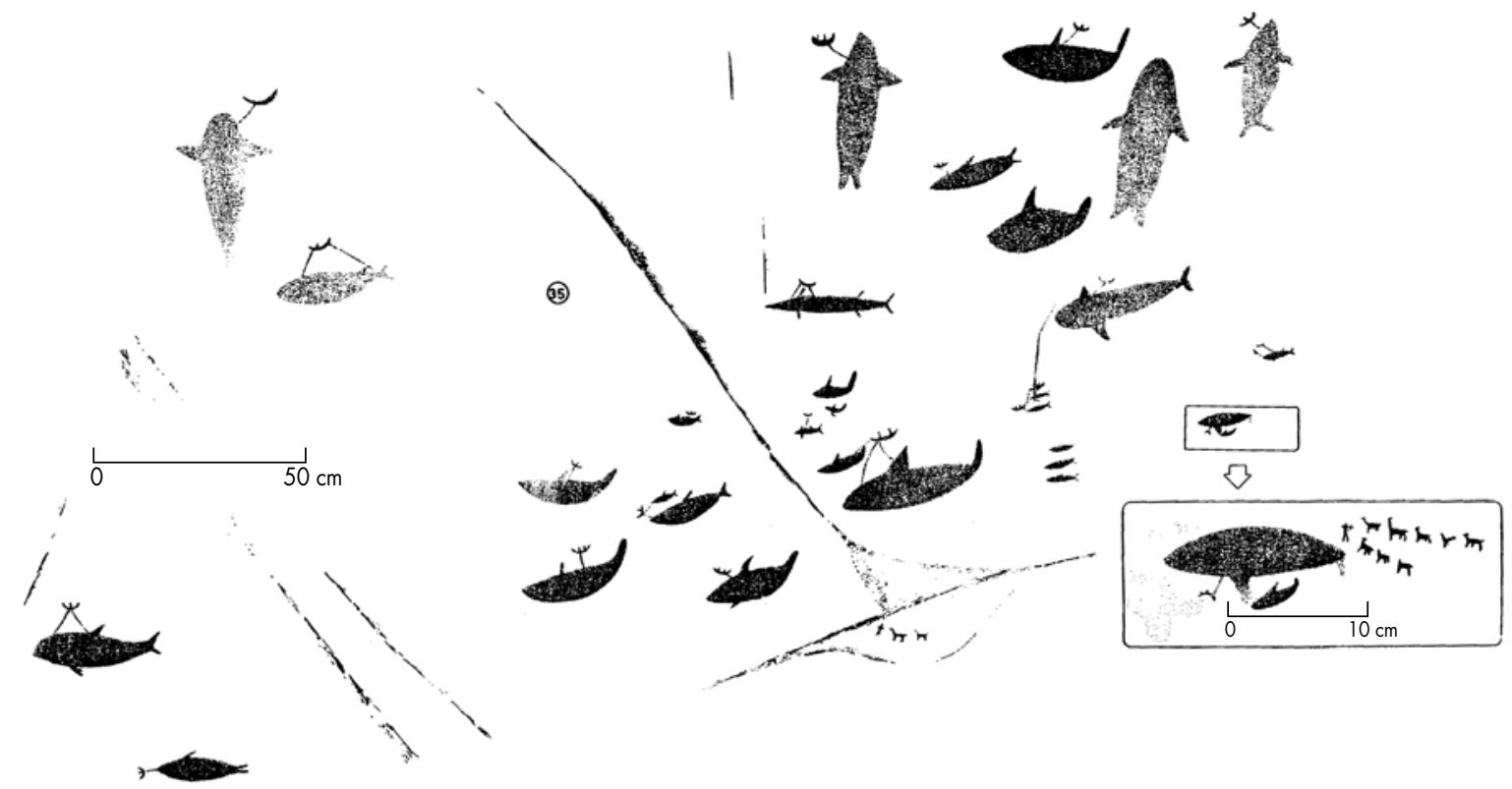

Figura 24. Pictografía en gran formato y múltiples temas (panel 35).

Figure 24. Large format, multi-thematic pictograph (panel 35).

"presente etnográfico" del siglo XVII y el tiempo prehispánico de las pinturas. Pese a que Vásquez de Espinosa no dice nada sobre la captura de albacoras, tortugas u otras especies y tampoco acerca de maniobras de remolque de cetáceos desde balsas de cuero de lobo, como aparece en las pictografías, hay que reconocer que la existencia de representaciones de balsas sin tripulantes, a modo de boyas atadas a presas que se mantienen a flote con la embarcación que las capturó (Niemeyer 1985: 145), es un elemento que calza muy estrechamente con lo que describe el cronista (fig. 25).

Según Llagostera (1990: 47), sin embargo, el relato de Vásquez de Espinosa no alude realmente a ballenas y cachalotes, sino a calderones, que son cetáceos gregarios de 5 a $8 \mathrm{~m}$ de largo que suelen permanecer inmóviles cuando el mar está tranquilo, conducta que coincide con lo que cuenta el cronista. Argumenta que en los dos primeros la aleta dorsal se encuentra desplazada hacia la región caudal, donde una estocada no produce daño vital, en cambio en el calderón la aleta se ubica prácticamente sobre la caja torácica, donde la penetración de un arpón sí produce daños irreparables. Empero, es muy claro que las pinturas representan escenas de captura de grandes mamíferos marinos, como es el caso de los cachalotes (fig. 26). Por lo tanto, estas visiones contrapuestas reinstalan las dudas de Mostny y Niemeyer sobre si las escenas pintadas expresan hechos reales o situaciones exageradas. Al menos, con los elementos de juicio disponibles, resulta imposible decidir a favor de una $\mathrm{u}$ otra de estas visiones. Estamos ante un caso fronterizo entre aquel en que el arte rupestre se cruza, tal vez, con las incompletas etnografías tempranas, y aquel otro en que la conexión entre arte y etnografía se desvanece, ya que el arte rupestre dejó de producirse y el modo de vida original de los changos se disolvió mucho antes de que los primeros etnógrafos profesionales tuvieran oportunidad de arribar al área.

\section{Cacerías de guanacos}

Hay todo un apretado relato cuando, comentando una imagen, Niemeyer dice que "los cardúmenes realmente sufren el pánico de la persecución del lobo marino" (Niemeyer 1985: 145, cursivas mías). Otro tanto ocurre con las escenas de camélidos. Tomándose similares licencias narrativas, los autores escriben: "Un arquero enfrenta a la tropilla que desciende por la quebrada" (Mostny \& Niemeyer 1983: 48, cursivas mías). Pero el tratamiento de las imágenes es narrativo también en un sentido más restringido (sensu Lewis-Williams 2000): Mostny y Niemeyer asumen que a través de estas escenas pueden determinar de manera directa la orientación económica de los pintores y sus comunidades. Para ellos, las escenas de caza de camélidos (y también las de balsas y presas) constituyen un vívido registro del modo de vida de los changos prehispánicos de Taltal.

En el caso de los camélidos, éstos son representados solamente en grupos, plasmados generalmente 
a
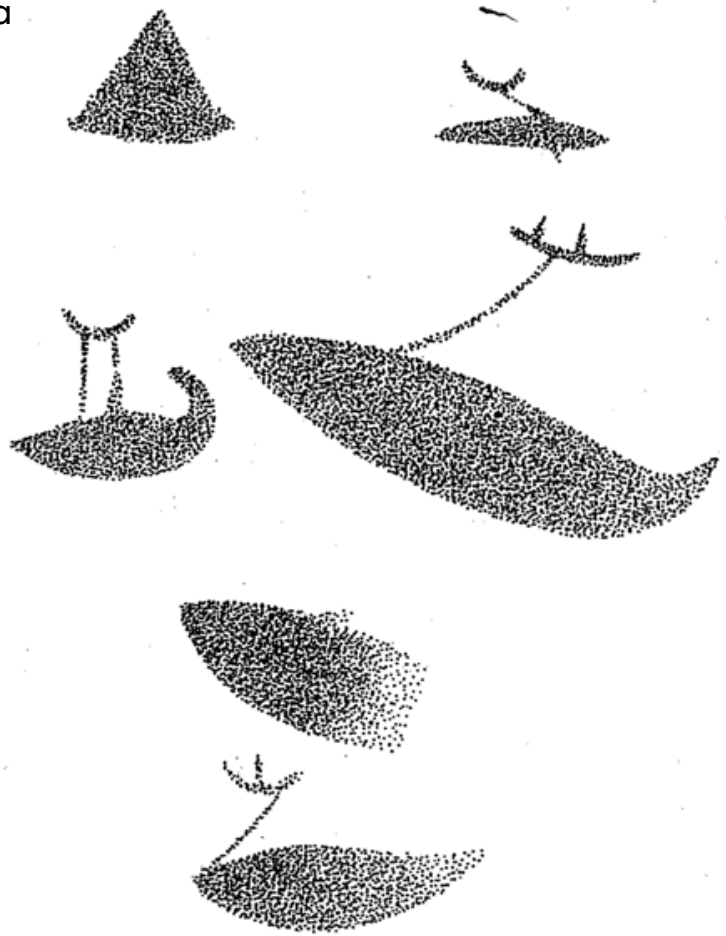

L $40 \mathrm{~cm}$

Figura 25. Balsas como boyas: a) panel 29-K; b) panel 29-W. Figure 25. Rafts used as floats: a) panel 29-K; b) panel 29-W.

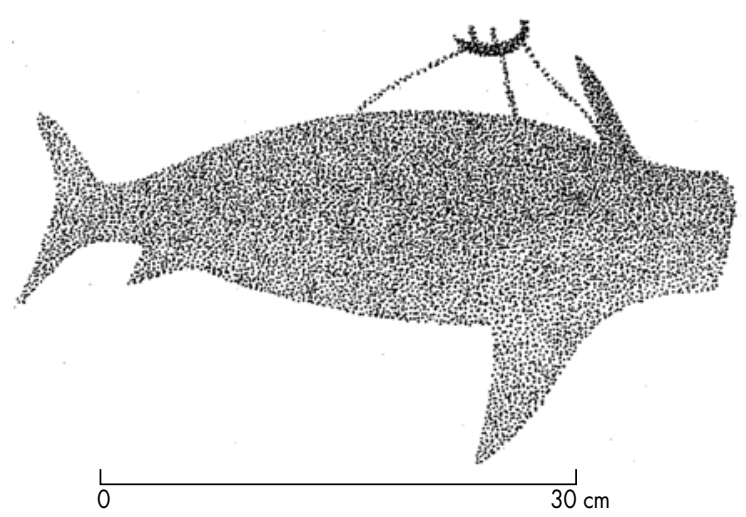

Figura 26. Captura de cachalote desde balsa de cuero de lobo (panel 36).

Figure 26. Capture of a sperm whale from sea lion skin raft (panel 36).

con dos, a veces tres y rara vez cuatro extremidades, por lo común en unión asociativa con un individuo humano (no en unión vinculada o constructiva como en las balsas) y muchas veces compartiendo paneles con escenas oceánicas (figs. 24 y 27). Aunque la cita de b
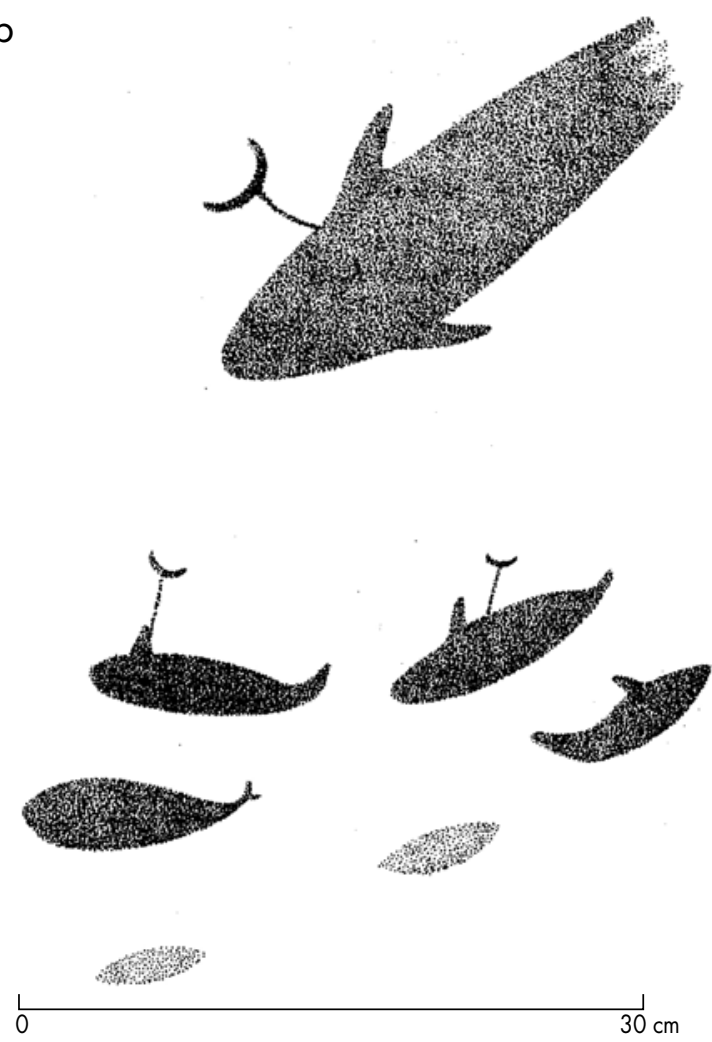

Vásquez de Espinosa (1948 [1628-1629]: 618-619) señala que "los indios de esta costa" salpresan pescados "del [que] se lleuan grandes recuas de carneros [llamas: Lama glama]" hacia el interior, Mostny y Niemeyer (1983: 48, 50-51; 1984: 3-5) no identifican a estos camélidos como llamas cargueras, sino como guanacos (Lama guanicoe), especie cuya existencia en la zona de El Médano puede constatarse hasta el día de hoy. Los elementos clave para su identificación como camélidos silvestres son el individuo que los enfrenta con un arco y la flecha que varios de los animales llevan clavada en el pecho. Por lo general, se observa en estas composiciones lo que Colle (1998: 26) llama una coherencia formal-semántica, esto es, una concordancia entre el sentido en que se desplazan los guanacos, el cazador que les sale al paso para ultimarlos y la zona del cuerpo impactada por el proyectil.

Incidentalmente, digamos que una particularidad en una de las escenas de guanacos es que algunos ejemplares parecen llevar representado el órgano sexual masculino, lo que permitiría diferenciar entre machos y hembras, y quizás, distinguir entre tropillas formadas por machos inmaduros (véase Mostny \& Niemeyer 1983: Fig. 58) y 
a

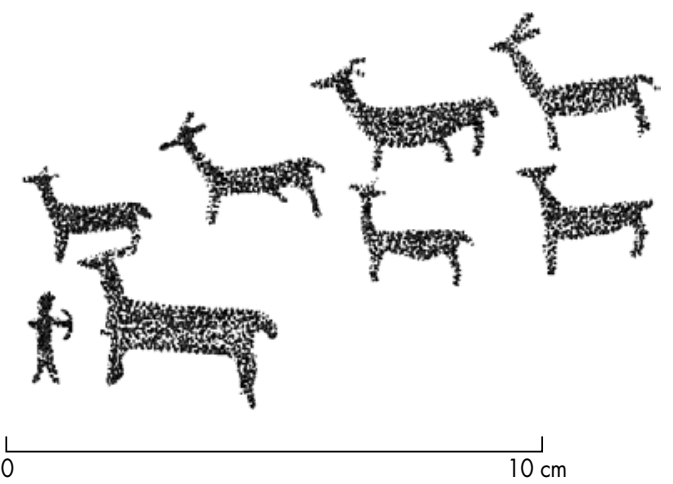

b

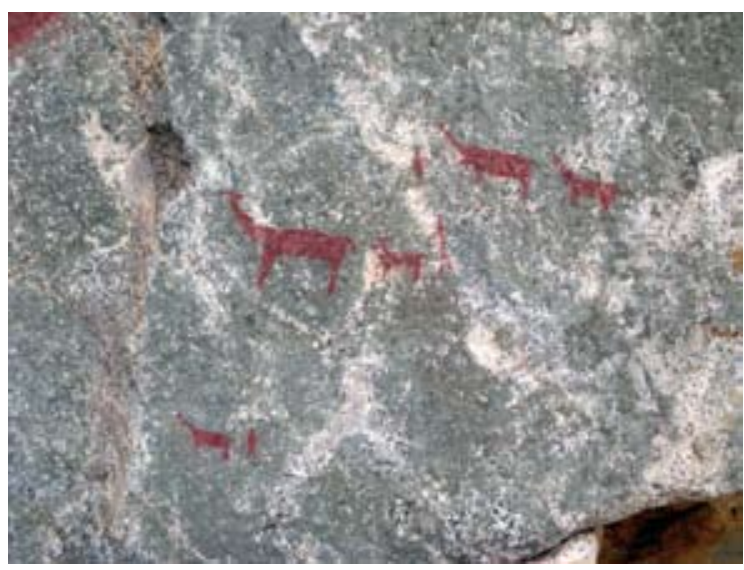

C

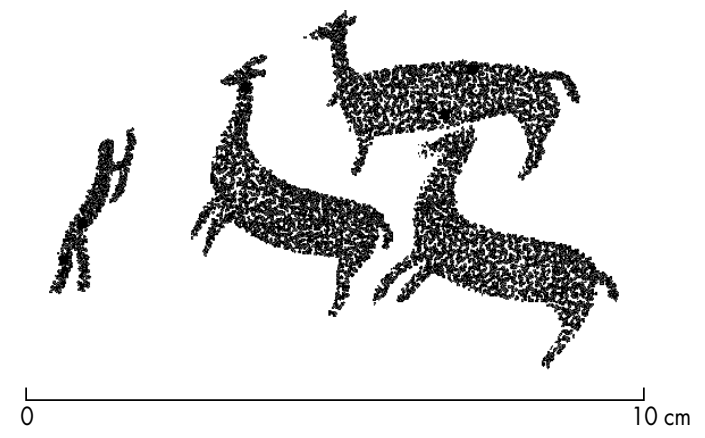

Figura 27. Caza de guanacos: a) panel 51-B (foto: J. Berenguer); b) detalle panel 34-B; c) panel 51-C.

Figure 27. Guanaco bunting: a) panel 51-B; b) panel detail 34-B; c) panel 51-C.

tropillas integradas por un macho alfa y sus hembras. No he notado hasta ahora este tipo de distinciones en otras escenas similares de la quebrada, por lo que es válido preguntarse si los camélidos con falos son una rareza o un error de relevamiento. La fotocopia de este dibujo se encuentra extraviada (véase Nota 7), pero el croquis de campo de Niemeyer de este panel revela, al menos, que los vio de esa manera al momento de dibujarlos en terreno (fig. 28).

En el manuscrito "Los peces (colaboración del Dr. Alfredo Cea E.)", se acota con justeza que la presencia de arqueros y arponeros en un mismo panel subraya la idea de una técnica cazadora común con armas arrojadizas. Como el tratamiento expresivo de cazadores y presas es similar al de las escenas marítimas, Mostny y Niemeyer los consideran parte del mismo estilo, interpretando implícitamente la economía de los autores de las pictografías como basada en recursos marinos y terrestres. No obstante, el conteo preliminar de Niemeyer en su manuscrito "Apuntes de campo" muestra que las figuras terrestres dan cuenta de menos del 10\% del total de figuras del sitio (véase Tabla 1). Por eso, tal vez la frase que mejor se ajusta a este tipo de lectura narrativa sea la que Niemeyer expresa en su "Crónica del rescate", cuando matiza que las imágenes revelan "fundamentalmente una economía de estricta dependencia marítima complementada minoritariamente con la caza terrestre de camélidos" (véase también Núñez, L. 1984a).

\section{El valor indicativo de las exclusiones}

A nadie puede resultar extraño que los pintores de El Médano hayan escogido animales de su ambiente inmediato como elementos de su discurso visual. Lo que sí sorprende es que entre ellos no se encuentren representaciones de aves, moluscos, crustáceos y equinodermos, toda vez que los desperdicios en los campamentos del litoral (Castelleti 2007) y el hallazgo en cementerios de esta época de instrumentos especializados en la recolección de este tipo de fauna (Mostny 1964; Núñez, L. 1984a; Salazar et al. 2009) muestran que muchos de esos recursos formaban parte del menú de los habitantes de la costa de Taltal. En otras palabras: la ocurrencia de motivos faunísticos en la quebrada no refleja la ocurrencia real de las criaturas del ambiente de la zona ni su importancia relativa en la alimentación de los pintores y sus comunidades de base.

Ignoro las causas de estas exclusiones, pero es claro que las preferencias icónicas de los pintores no se explican por razones sólo de dieta. Al parecer, la preocupación de esos artistas no estaba en plasmar especies fácilmente disponibles en la zona intermareal. Estaba, más bien, en representar aquellas de costa afuera, cuya captura era más difícil o incierta, debido al riesgo y esfuerzo que implicaban, o, a lo mejor, porque su aparición en la costa estaba sujeta a ciclos no siempre predecibles, como tendremos oportunidad 


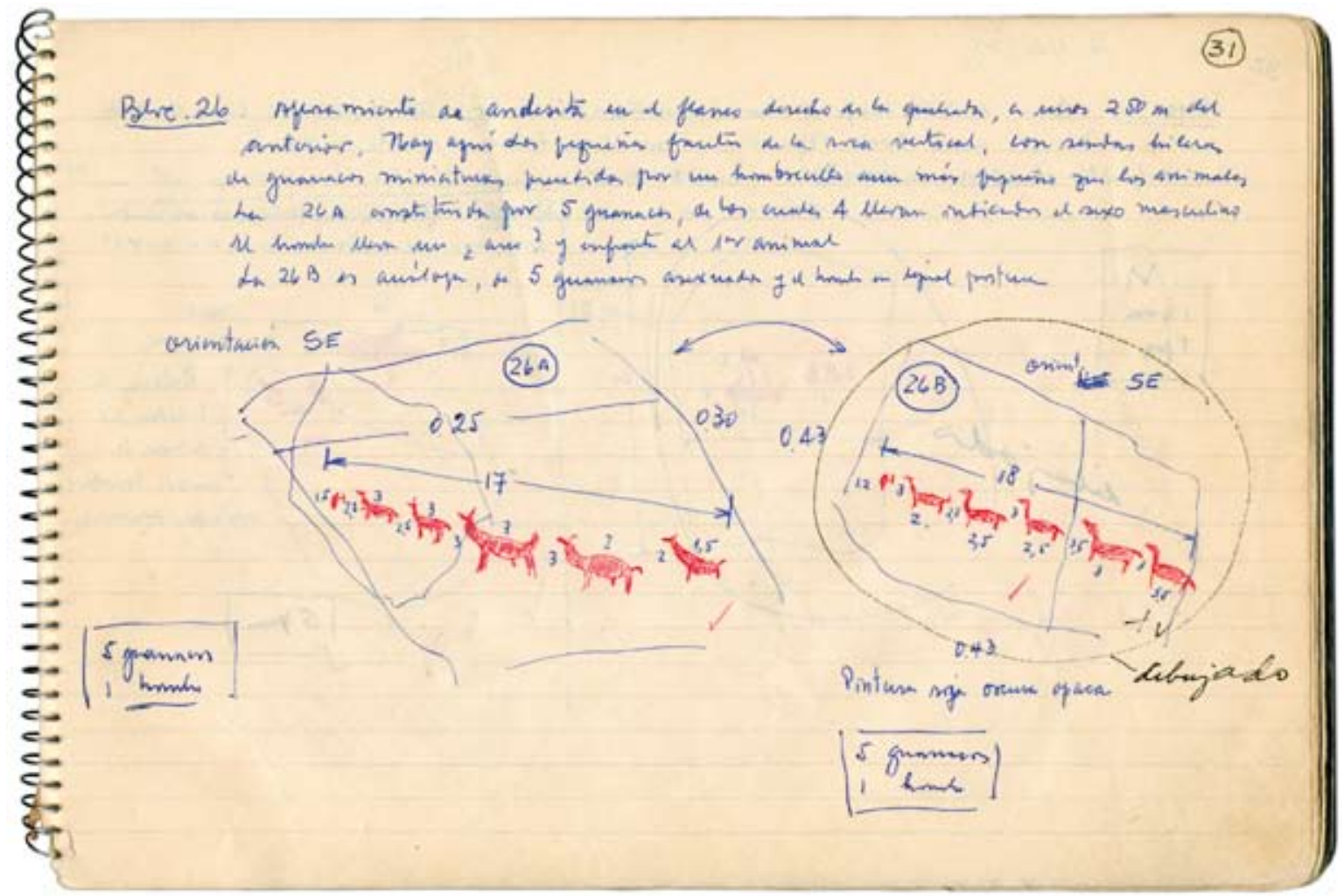

Figura 28. Croquis de paneles 26-A y 26-B ("Apuntes de campo", página 31).

Figure 28. Sketch of panels 26-A and 26-B ("Apuntes de campo" (Field Notes), page 31).

Tabla 1. Conteo de figuras de H. Niemeyer en "Apuntes de campo" Table 1. H. Niemeyer's figure counts, from "Apuntes de campo" (Field Notes)

\begin{tabular}{|l|c|c|c|}
\hline \multicolumn{1}{|c|}{ Categoría } & H. Niemeyer & Totales & Porcentaje \\
\hline Peces* & $625+306$ & 931 & 64,20 \\
\hline Balsas & $223+101$ & 324 & 22,34 \\
\hline Hombres & 28 & 28 & 1,93 \\
Guanacos & 133 & 133 & 9,17 \\
\hline Tortugas & 3 & 3 & 0,20 \\
\hline $\boldsymbol{\Delta}$ & 18 a 20 & 18 a 20 & 1,24 \\
\hline Enrejados & Sin información & 10 & 0,68 \\
\hline Zorros & 1 & 1 & 0,68 \\
\hline W & Sin información & 2 & 0,13 \\
\hline Total & & 1.450 a 1.452 & 99,95 \\
\hline
\end{tabular}

* Esta categoría incluye peces propiamente tales, cetáceos y, tal vez, lobos marinos.

* This category includes fish, whales, and probably sea lions.

de discutir más adelante. Podría sugerirse, en consecuencia, que el valor de significación de las pinturas de El Médano estaba relacionado con una finalidad o función que no era la de narrar eventos únicos o describir aspectos de su modo de vida, posibilidad que discutiré en seguida. 


\section{PROPÓSITOS DEL SITIO Y SUS PINTURAS}

Gombrich (1999: 39) sostiene que para comprender el arte de otra época no se pueden ignorar por completo los fines a que sirvió. Mostny y Niemeyer (1984: 3) satisfacen este precepto cuando proponen que el yacimiento pictográfico de la quebrada El Médano fue "un inmenso santuario de arte votivo en pro de la buena pesca y sobre todo de la caza feliz de grandes animales marinos y de guanacos". Al hacerlo, reconocen que el mensaje icónico de estas pinturas porta una "carga interpretativa" que trasciende la simple identificación de su referente o que va más allá de la mera descripción de su estilo de vida. En esta tesis la quebrada ya no sería "un lugar para contar". La representación pictórica de esos animales estaría asociada a un poder mágico: representarlos en las piedras sería tener poder sobre ellos, plasmarlos realizaría su presencia. ${ }^{26}$

Es oportuno reconocer los méritos de estas reflexiones. A principios de la década de 1980, formulaciones como éstas estaban casi vedadas en la arqueología, incluso todavía despiertan resistencia. Planteando estas ideas en aquel entonces, Mostny y Niemeyer estaban introduciendo enfoques diferentes del consenso local y con ello, intentando lecturas menos literales, o, lo que es lo mismo, aproximaciones más interpretativas al arte rupestre (sensu Lewis-Williams 2000). A continuación, procuraré ejemplificar esto elaborando algunas ideas que se derivan de su propuesta. Por supuesto, esta parte de mi análisis es más especulativa, pero sirve para ejemplificar el valor heurístico que tienen sus reflexiones para una arqueología del arte rupestre con perspectiva antropológica. En particular, para desarrollar nuevas plataformas de discusión como una etapa previa para, más adelante, formalizar estas ideas como hipótesis de trabajo (véase Berenguer 2004b: 76).

\section{Singularidades de la quebrada}

¿Por qué estos grupos costeros eligieron a la quebrada El Médano como lugar de concentración de sus pinturas? Después de todo, es tan sólo una de las muchas quebradas que se originan en puntos altos de la cordillera de la Costa y se abren camino al litoral a través de esta cadena montañosa. Una razón para singularizarla podría residir en su aislamiento. Ninguno de los dos trabajos que comentamos (tampoco la "Crónica del rescate") hace plena justicia a las dificultades que representa llegar al lugar, incluso con los medios actuales (Núñez \& Contreras 2003: 31).

Es claro que la quebrada no fue un espacio público, un lugar abierto a cualquiera (fig. 29a-b). Invisible desde el borde costero, casi inaccesible debido al empinado farallón rocoso donde desemboca a gran altura la vaguada y a varias horas de camino de los campamentos del litoral, el yacimiento de El Médano reúne todas las características de un lugar oculto o secreto, elegido con lo que parece ser una deliberada intención de clausura social, de restringir el acceso al común de la gente. Quienes hacían el trayecto desde la playa, debían ascender más de $1000 \mathrm{~m}$ del acantilado costero, con frecuencia abriéndose paso por una densa y húmeda capa de bruma de varios centenares de metros de espesor, para llegar
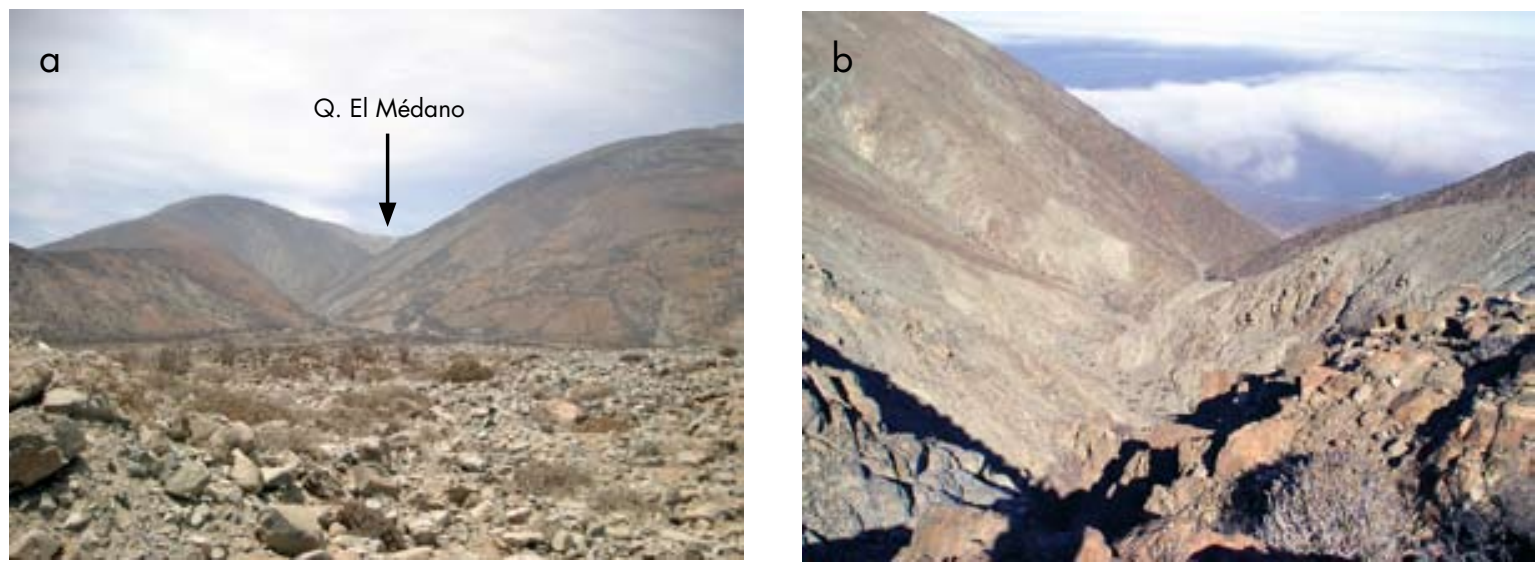

Figura 29. a) Desembocadura de la quebrada El Médano en el farallón costero vista desde el abanico aluvial de la quebrada en la planicie litoral (foto: J. Berenguer); b) punto del curso medio de la quebrada en donde ésta cae abruptamente hacia la plataforma costera (foto cortesía de H. Gárate).

Figure 29. a) Headland at the mouth of the El Médano ravine, as seen from the ravine's alluvial fan on the coastal plain; b) point in the middle ravine where it drops abruptly to the coastal platform (photo courtesy of H. Gárate). 
recién al ambiente seco, silente y soleado donde está el "santuario votivo" (fig. 30). ${ }^{27}$ Es como si sólo sujetos con capacidades fuera de lo normal, viviendo circunstancias muy especiales o pertenecientes a un grupo muy selecto, hubieran estado facultados para ascender el escarpe, atravesar la niebla liminal que divide al océano del desierto y pintar "de memoria" las imágenes que aseguraban la subsistencia del grupo y su reproducción como comunidad (Berenguer 2008a: 61).

Ignoramos quiénes eran estos "sujetos", pero existen pistas que permiten explorar el tema. Refiriéndose a los habitantes de la costa de la Región de Antofagasta, por ejemplo, Vivar (1979 [1558]: 18) apunta:

"Y los que matan lobos no matan otros peçes, como avemos dicho, y los que matan toninas es en exerçiçio. Asy que cada genero de pescador mata el genero de pescado a que se afiçiona y no otro".

El relato deja entrever la existencia de una división del trabajo, una especialización de los "indios pescadores" en la captura de diferentes especies marinas (Núñez, P. 2003). Quizás no todas estas especializaciones tenían el mismo prestigio al interior de las comunidades litoráneas (Contreras et al. 2008). A juzgar por las representaciones de animales en las pictografías de El Médano, los individuos que se dedicaban a la explotación de los recursos de orilla o zona intermareal carecían del reconocimiento social suficiente como para acceder al espacio privilegiado de la quebrada y participar de los ritos allí realizados. Ese privilegio parece haber estado reservado a los pescadores, cazadores y navegantes del piélago.

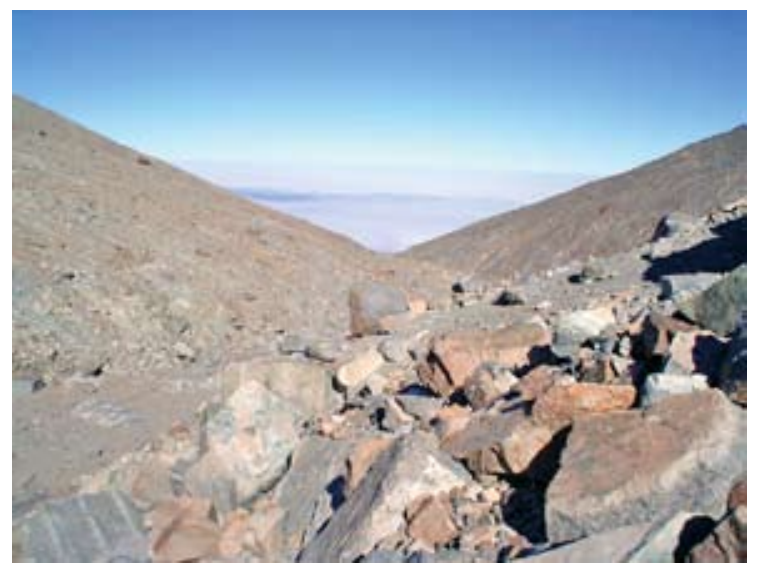

Figura 30. Tramo superior y medio de la quebrada donde están las pinturas. Al fondo, la espesa capa de niebla o camanchaca que cubre normalmente la costa (foto cortesía de H. Gárate).

Figure 30. Upper and middle reaches of the ravine, where the paintings are located. In the background is the thick layer of camanchaca fog that usually blankets the coast (photo courtesy of H. Gárate).
No lo he comprobado a ciencia cierta, pero supongo que El Médano no es la única quebrada con esas características de localización en la costa de Taltal, por lo que una razón adicional para explicar su elección como "santuario" podrían ser sus aguadas. Un estudio de Núñez y Varela (1968) reporta más de 70 aguadas en la costa desértica del norte de Chile. Para aquilatar la importancia de éstas, hay que entender que eran casi la única fuente de agua para consumo humano, que estaban a mucha distancia unas de otras y que su escaso volumen permitía abastecer sólo a grupos muy pequeños (Larraín 1974). ${ }^{28}$ Un mapa de Núñez y Contreras (2003), en que superponen aguadas y sitios con pictografías en el área de Taltal, permite constatar que, si bien no todas presentan sitios de arte rupestre, todos los sitios de este tipo poseen una aguada activa o extinta en sus proximidades (fig. 13). Esta correlación sugiere fuertemente que la elección de los lugares para pictografías estaba determinada por la disponibilidad de agua fresca. Basado en la Carta Preliminar del IGM, en 1956 un pariente de Capdeville (Larraín 1974: Nota 23) mapeó las 42 aguadas reportadas por Capdeville 2008 [1923]: 29-34) entre Caleta Botija y Taltal, cuatro de las cuales localiza muy cerca de las "Piedras Pintadas de la Quebrada Médano" (véase Mostny 1964, T. I: 148-151, Nota 355, Plano III). En consecuencia, este mayor número de aguadas puede haber sido otro importante elemento diferenciador de la quebrada que habría incidido en su selección como espacio ritual.

\section{Cambios climáticos y actividad ritual}

Se mantiene, no obstante, la interrogante acerca de qué circunstancias pueden haber llevado a estos grupos costeros a desarrollar una actividad votiva tan intensa en la quebrada. ¿Por qué esta suerte de compulsión por pintar tal cúmulo de imágenes rupestres en las piedras de la vaguada? Una posible respuesta podría tener que ver con la variabilidad climática verificada en los últimos tres mil años, debido al carácter que durante ese lapso habrían asumido las interacciones de gran escala que se producen entre la atmósfera y el océano a lo largo de toda la costa desértica de Chile y Perú (Berenguer 2008a: 58, 2008c: 20).

Me explico. Normalmente, quebradas como la de El Médano permanecen secas durante años, incluso décadas. Cada 11 a 30 años, sin embargo, llueve copiosamente en el desierto interior (IGM 1990: 59) y las aguas bajan en aluvión por ellas (Berenguer 2008a: 59), precipitándose en cascada hacia la plataforma costera (fig. 31). Observaciones basadas en registros históricos de precipitaciones en los dos últimos siglos en el norte 


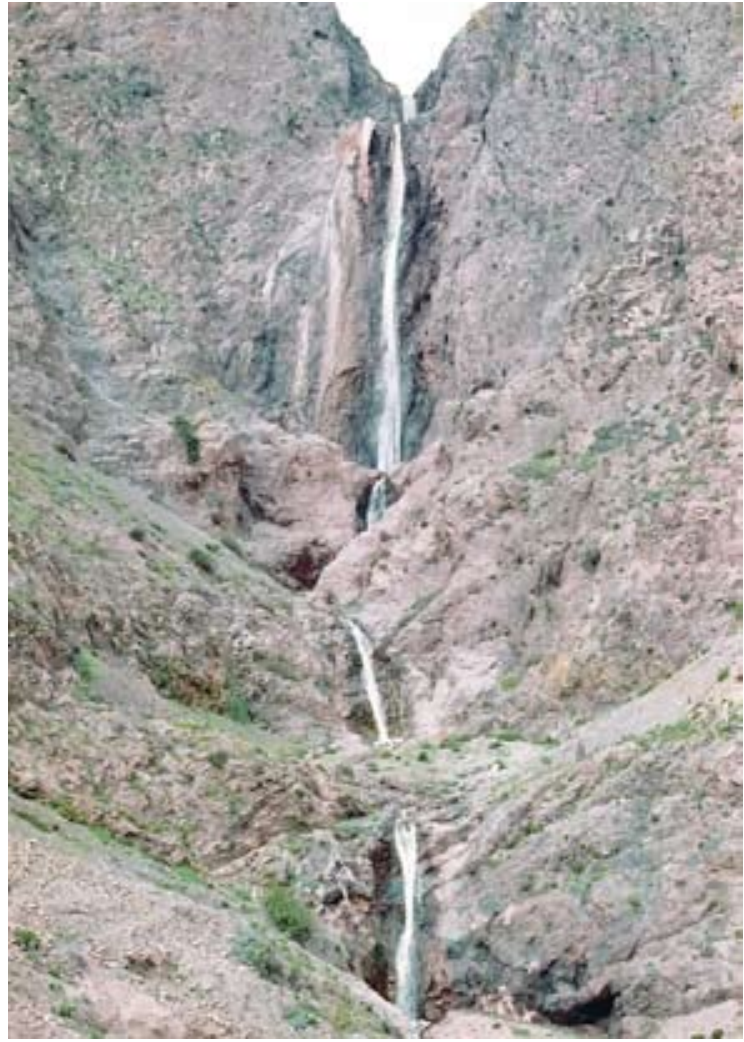

Figura 31. Cascada en la quebrada de Bandurrias, al sur de El Médano, en junio de 1991 (foto: Roberto Perucci, Archivo Museo Augusto Capdeville, cortesía de Rodolfo Contreras).

Figure 31. Waterfall in the Bandurrias ravine, south of El Médano, in June 1991 (photo: Roberto Perucci, Archives of the Museo Augusto Capdeville, courtesy of Rodolfo Contreras).

de Chile, muestran que la ocurrencia de precipitaciones en el desierto de Atacama coincide por lo general con eventos El Niño. Estos registros revelan, por ejemplo, que entre 1819 y 1991, 21 de 32 episodios de lluvia en el desierto se relacionan con estos eventos (Ortlieb 1995: 535).

Se ha visto en el norte de Chile que los eventos "El Niño-Oscilación del Sur" (ENSO, por sus siglas en inglés) producen un gran impacto en las aguas costeras, provocando el colapso de la actividad pesquera local, una gran mortandad de organismos marinos y aves, mareas rojas, lluvias torrenciales, erosión de las tierras bajas de la costa e inundaciones. Los principales efectos, sin embargo, son sobre la biomasa de la costa, ya que se interrumpen las cadenas tróficas de los ecosistemas marinos (Williams et al. 2008). Se produce la desaparición masiva de fitoplancton, zooplancton, macroalgas e invertebrados del litoral, la muerte o migración de las aves marinas, la aparición de organismos inusuales en estas aguas y el alejamiento de muchas especies hacia alta mar (Allendes 2000), con previsibles consecuencias para las comunidades humanas que viven de esos recursos.

En un reciente estudio basado en 331 fechas radiocarbónicas de la franja costera situada entre $16^{\circ} \mathrm{y}$ $25^{\circ}$ Latitud Sur y 530 fechas del interior del desierto de Atacama, como una aproximación a los cambios de población, Williams y colaboradores (2008) exploran las respuestas de las poblaciones prehispánicas a la variabilidad climática del ENso. Sostienen que los datos arqueológicos del desierto de Atacama muestran un aumento gradual de la población desde 11.000 AC y un incremento importante durante el óptimo climático del Holoceno Medio, indicando que la cultura Chinchorro gozó en ese período de un ambiente marino particularmente rico, estable y altamente predecible. Notan estos autores que la intensificación del ENSO a partir de $1700 \mathrm{AC}$ se correlaciona con ciclos de florecimiento y declinación de la población, incluyendo el colapso hacia $1000 \mathrm{AC}$ de la distintiva economía marítima especializada que caracterizó a Chinchorro (y derivados meridionales), así como la declinación de la población en las zonas interiores del desierto entre esa fecha y los comienzos de nuestra era. Se produce en esos momentos el abandono de muchos sitios costeros, cambios en los patrones funerarios desde la momificación artificial y los entierros colectivos a rituales menos complejos en entierros individuales, una brusca ampliación de la base económica marina para incluir productos hortícolas y la creación de redes de intercambio más extensas. Si bien las poblaciones se recuperan gradualmente después de 500 AC, lo hacen sobre la base de una economía que combina agricultura con explotación marítima, aunque el incremento no alcanza los niveles del Holoceno Medio. Otro pulso de fuerte declinación se produce a inicios de nuestra era, después de lo cual el sostenido crecimiento de la población refleja la expansión de organizaciones políticas de pequeña escala, vinculadas a estructuras mayores como Tiwanaku e Inka.

Queda en evidencia, no obstante, que el modelo propuesto por estos autores refleja, más bien, la situación de la costa del extremo norte de Chile y, quizás, del interior del desierto. En ningún caso, la de áreas como Taltal, carentes de condiciones para las prácticas agrícolas, donde esa variabilidad ambiental es difícil que haya podido operar como catalizador para ampliar la base económica e incluir cultivos tropicales (cf. Williams et al. 2008). Tan sólo los vínculos de intercambio con el interior, que estos autores proponen, pueden haber mitigado en algo el colapso de los asentamientos costeros que ellos dicen visualizar a partir de $1000 \mathrm{AC}$. 
Revisando la literatura arqueológica sobre Taltal, se observa un consenso entre los investigadores de que existe una continuidad en el tiempo de los modos de vida arcaicos (Núñez, L. 1984a; Castelleti 2007; Salazar et al. 2009), aunque los primeros dos autores los extienden hasta momentos prehispánicos tardíos y los últimos, sólo hasta el Período Formativo. Por otra parte, mientras Castelleti (2007) nota un aumento de población en el Formativo y una declinación en los períodos Intermedio Tardío y Tardío, Salazar y colaboradores (2009) advierten todo lo contrario. Además, la tesis de explotaciones multiétnicas de L. Núñez (1987), de alguna manera seguida por Castelleti (2007), es relativizada por Salazar y colaboradores (2009). Aducen estos últimos que los materiales alóctonos encontrados en los cementerios de Taltal (Mostny 1964, Comp.), aparecen consistentemente asociados en las tumbas con instrumental de pesca y caza marina (la misma observación hace Castelleti, comunicación personal 2007). Sugieren que la presencia de esos materiales ocurre vía intercambios con los oasis interiores, y, en el caso de materiales de Arica y de Copiapó, merced a la masiva incorporación de la balsa de cuero de lobos durante el primer milenio de nuestra era. Añaden que los objetos foráneos se introducen en los contextos sociales y económicos de los grupos locales. Así, el cambio entre el Arcaico Tardío y los momentos "alfareros" se produciría en Taltal "recién en el Intermedio Tardío, con un notorio aumento de la movilidad residencial" (Salazar et al. 2009: 115).

Resultados preliminares de un estudio de los registros sedimentarios de las sucesivas condiciones oceanográficas de los últimos milenios, realizado en la Bahía de Mejillones, indican que entre los siglos v y xvı se produjeron varios ENSO particularmente intensos (Ortlieb et al. 2000). Dos de ellos, interpretados por los investigadores como posibles "mega" El Niño (de gran intensidad y duración), habrían ocurrido hacia 600 y 1000 DC, y el otro hacia 1200 DC. Según el estudio, al menos los dos primeros habrían estado asociados a lluvias más intensas que las conocidas en el registro histórico de precipitaciones del desierto de Atacama. Esto quiere decir que, en ciertos momentos de la amplia ventana de tiempo en que hemos estimado hubo actividad rupestre en la quebrada El Médano (véase supra), las comunidades costeras habrían experimentado condiciones de estrés ambiental de una magnitud tal, que superan todo cuanto se conoce a este respecto en la época histórica. Si estos eventos reflejan una situación más generalizada en este período, tal cosa sería motivación de sobra, pensamos, para generar cambios en los patrones de asentamiento y movilidad, así como una ampliación de las redes de intercambio (Castelleti 2007; Salazar et al. 2009), pero también para desencadenar o intensificar prácticas rituales como las propuestas en clave interpretativa por Mostny y Niemeyer para El Médano.

Parece razonable pensar -si bien imposible de demostrar por ahora- que la observación de que después que aumentaba la temperatura superficial del mar por efectos de un ENSO generalmente llovía en el desierto, condujo a los habitantes de la costa a relacionar simbólicamente la escasez de los recursos marinos con las quebradas por donde descendían los caudales que trastornaban cíclicamente sus vidas. No es difícil imaginar cuán acuáticas deben haber lucido las pictografías en momentos en que la quebrada se convertía en un torrente. A este respecto, Contreras et al. (2008) notan que las pinturas tienden a concentrarse en los varios escalones o "saltos de agua" que hay a lo largo de la quebrada (cf. Niemeyer, "Crónica del rescate"). Esto sugiere que, si efectivamente hubo actividad rupestre votiva en El Médano, ésta habría tenido que ver con una conexión simbólica que los pintores hacían entre ciertas imágenes marinas y el agua de estos episódicos caudales (fig. 32). Mediante imágenes pintadas principalmente en los "saltos" de la vaguada, los artistas prefiguraban lo que la comunidad deseaba: el regreso de los cardúmenes, la vuelta de las grandes especies marinas y la restauración de la normalidad. Por paradójico que resulte, los pintores de El Médano ascendían a la quebrada y se asomaban a uno de los desiertos más áridos del mundo para propiciar el retorno de las especies marinas.

Tal vez por eso en la quebrada se repiten como fractales decenas de paneles con un mismo tema. Por ejemplo, en los dibujos de Niemeyer existen 324 escenas de balsas que arrastran uno o más peces, tortugas o cetáceos (Tabla 1). Algunos paneles contienen hasta 21 de estas embarcaciones (fig. 33). Otro tanto ocurre con las escenas de guanacos, aunque en muchísimo menor número (17 según los dibujos de Niemeyer). Una posibilidad, consistente con la tesis votiva de Mostny y Niemeyer, es que la recursividad de los temas haya sido parte esencial de la eficiencia del ritual desiderativo. Se habrían pintado cada vez que fuese necesario, como una manera de "hacer votos" por pescas y cazas exitosas (Mostny \& Niemeyer 1983: 116). De allí, entonces, la obsesiva repetición de estos temas en la quebrada.

Es posible que los guanacos se hayan cazado con mayor asiduidad en épocas de escasez de especies marinas. Por ejemplo, un viajero del siglo xIX nota que cuando el mar permanecía "bravo" o tempestuoso por mucho tiempo y no se podía salir a pescar, a los changos no les quedaba otra cosa que cazar guanacos (Bittman 1984a: 102, citando a Philippi 1866). Si esto ocurría durante situaciones críticas, pero comunes todos 

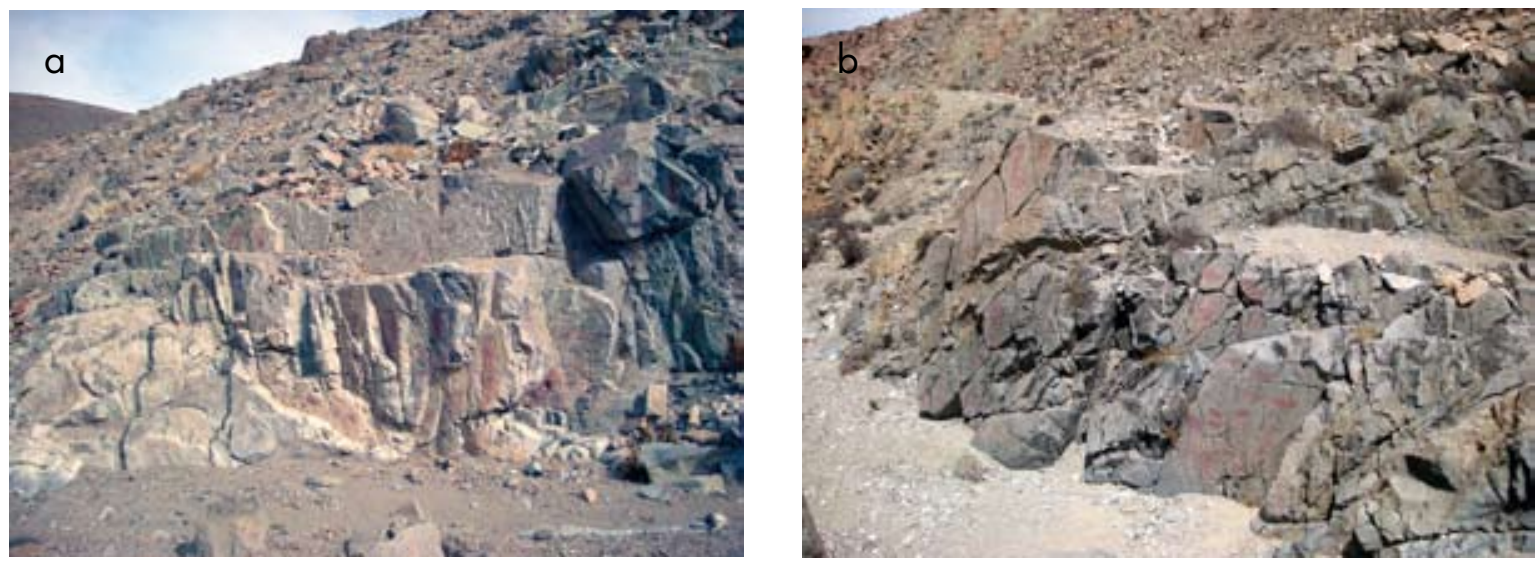

Figura 32. Pictografías en los "saltos de agua" de la quebrada (fotos: J. Berenguer). Figure 32. Pictographs at the "waterfall" sector of the ravine (photos: J. Berenguer).

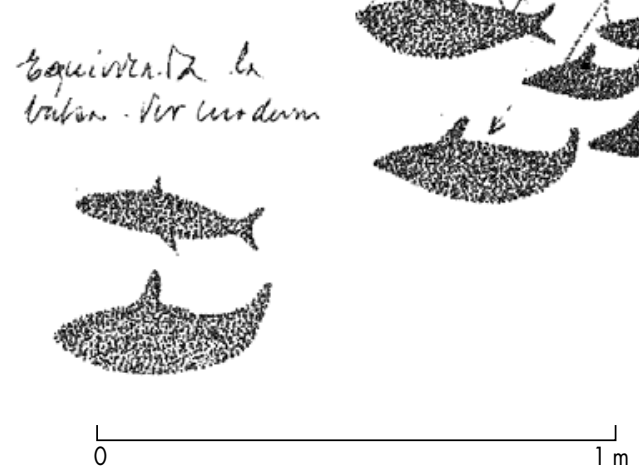

Figura 33. Las escenas de balsas arrastrando diferentes especies marinas se repiten una y otra vez en la quebrada (panel $41 \mathrm{G}$ ). Figure 33. Scenes of rafts towing different marine species appear repeatedly along the ravine (panel $41 \mathrm{G}$ ).

los años a lo largo de estas costas, puede anticiparse lo sucedido durante eventos El Niño de la intensidad y duración de los sugeridos por el citado estudio de Bahía de Mejillones. En esas épocas de aguda carestía de recursos marinos, el guanaco costero habría representado una crucial reserva de alimento. Este contrapunto oportunista entre explotación de recursos de tierra firme y del mar habría quedado reflejado en la quebrada a través de las escenas de arqueros cazando guanacos y balseros arponeando o pescando presas marinas, pero, también mediante el desbalance numérico entre ambos tipos de escenas.

Una vez inaugurada esta práctica ritual, la acumulación de las imágenes a lo largo de generaciones habría abonado a la eficiencia mágico-religiosa del rito (Martínez 2004), convirtiendo a El Médano en un espacio privilegiado para el "trabajo simbólico" (Van Kessel 1976). Una suerte de mundo virtual para relacionarse con las fuerzas que, en sus creencias, controlaban la disponibilidad de las especies y el éxito de las capturas. La quebrada se habría erigido en el lugar preferido para pedir fortuna para las expediciones de caza y pesca, ejerciendo atracción, quizás, sobre navegantes procedentes de un sector de la costa del norte de Chile más extenso que el solo litoral entre Caleta El Cobre y Taltal.

\section{LAS PINTURAS COMO EXPRESIÓN DE IDENTIDAD}

Un último punto a discutir es el de la identidad de los artífices de este arte rupestre. Mostny y Niemeyer (1984: 3,5) atribuyen el Estilo El Médano a ancestros prehispánicos de los changos históricos. En una publicación posterior, Niemeyer (1985: 146) aclara que no considera a los changos como una "cultura privativa de una raza o grupo étnico homogéneo, sino, más bien, es un género de vida que saca partido del mar y el litoral", y que sería al que se refieren los cronistas y viajeros de la Colonia y la República. Conocidos inicialmente como "uros pescadores", "camanchacas" o "proanches", desde mediados 


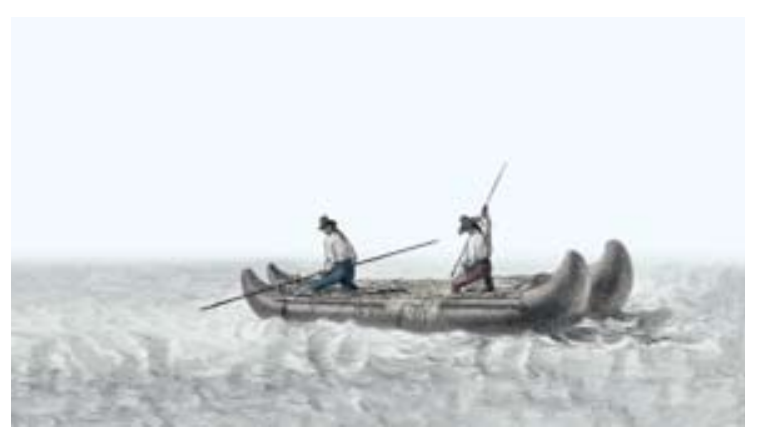

Figura 34. Balseros changos en una gran balsa de cuero de lobos (grabado en Alcides D'Orbigny, 1830).

Figure 34. Chango raftsmen in a large sea lion skin raft (engraving in Alcides D'Orbigny, 1830).

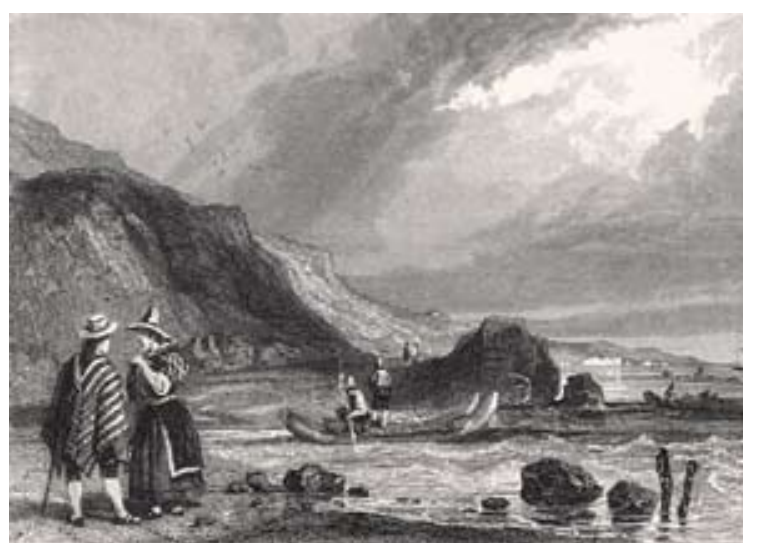

Figura 35. Changos navegando en una balsa de cuero de lobo de grandes proporciones (grabado en Philippi 1860).

Figure 35. Changos sailing a very large sea lion skin raft (engraving in Philippi 1860).

del siglo XvII estos grupos comienzan a ser denominados "changos" o "chiangos", apelativo que prevaleció hasta bien avanzado el siglo xx (Bittman 1984b). Serían grupos como éstos los que aparecen tripulando balsas de cuero de lobo en los grabados europeos de los siglos XVIII y $\mathrm{xIx}, \mathrm{y}$, conforme a nuestros autores, en las pictografías de El Médano (figs. 34 y 35). La pregunta que surge, entonces, es hasta qué punto este arte rupestre operaba como un discurso visual sobre la identidad de estas comunidades marítimas. ${ }^{29}$

\section{Imágenes de sí mismos}

Es de sobra conocido que en el norte de Chile, como en el resto del Área Andina, el traje señalaba la pertenencia de su usuario a un determinado grupo étnico o social (p. e., véase Berenguer 2006: 8-9, 40). Desgraciadamente, la información histórica no entrega mucho detalle sobre la indumentaria de los "indios pescadores" del norte de Chile, aunque coincide en señalar que vestían con pieles de lobo de mar (veáse Bittman 1984b: 106 y ss.):

Los indios de esta costa se visten de cueros de lobos marinos [...] y se vntan con aquella graça [de ballena], traen los cauellos rubios como el oro, o candelas, y como andan tostados del rigor del sol [...], es mucho de ver sus figuras, y acataduras, negras y los cauellos rubios (Vásquez de Espinosa 1948 [16281629]: 619).

[Entre el río Loa y Copiapó] hay algunas caletillas con poco agua salobre, donde se han recogido y huido algunos indios pescadores, pobres y cai desnudos; los vestidos son de pieles de lobos marinos [...] Llaman a estos indios Camanchacas, porque los rostros y cueros de sus cuerpos se les han vuelto como una costra colorada, durísimo; dicen que les proviene de la sangre que beben de los lobos marinos, y por ese color son conocidísimos (Lizárraga 1968 [1605?]: 50).

No conozco reportes de pieles de lobo marino usadas como atuendo por grupos pescadores prehispánicos del norte de Chile, pero en el cementerio Camarones-9, considerado del Período Tardío, se encontró una "diadema compleja" que incluye bigotes de este animal "en pequeños haces liados con lana teñida" (Horta 2000). Una posibilidad interesante a este respecto -aunque difícil de comprobar- es que los lobos marinos en posición vertical de las pictografías de El Médano (fig. 36) representan seres humanos transfigurados en ese animal (Núñez, P. 2003: 88-90; Contreras et al. 2008: 97). ${ }^{30}$ Existe allí otro tema para investigar, ya que puede haber habido una identificación entre la gente de la costa y estos pinnípedos. Ambos desarrollan su vida entre el mar y la tierra, tienen en común su condición de predadores de la fauna marina, poseen hábitos gregarios y se mueven a lo largo de la costa, a veces radicándose en

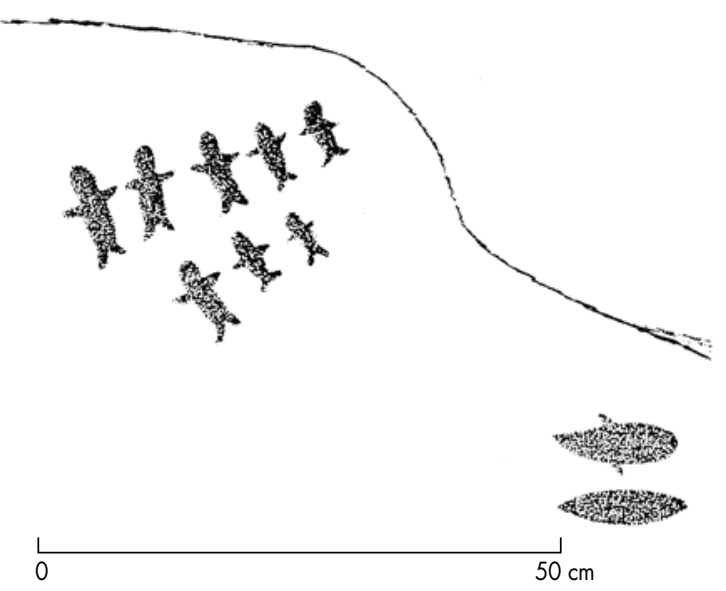

Figura 36. Lobos en proyección frontal dispuestos en posición vertical (panel 29-O $\mathrm{O}_{1}$ ).

Figure 36. Sea lions in frontal view, vertically positioned (panel 29- $\left.O_{1}\right)$. 
tierra firme en pequeños núcleos familiares y en otras ocasiones en grandes agrupaciones.

Independiente de lo anterior, el indumento cefálico parece ser una buena vía de indagación para el tema de la identidad. En efecto, uno de los elementos que habría caracterizado a las comunidades marítimas prehispánicas del norte chileno es la "diadema simple" (fig. 37a), un tocado confeccionado con plumas de pelícano (Horta 2000). La autora encuentra estos tocados concentrados en cementerios costeros de los períodos Intermedio Tardío y Tardío de Arica, principalmente en Playa Miller-3, pero también en Playa Miller 2, 4 y 6, y en menor cantidad en sitios localizados entre el valle de Camarones e Iquique, tales como Camarones-9, Patillos, Bajo Molle y Patache. Su atribución a poblaciones pescadoras deriva de que este tipo de tocado aparece asociado a implementos de pesca, caza y recolección marina, así como a miniaturas de balsas de "tres palos" y a remos (Horta 2000: Tabla 1). Así, la diadema de plumas de pelícano podría considerarse un diacrítico cultural o emblema de identidad de los pescadores prehispánicos tardíos del extremo norte de Chile. En línea con lo dicho en el párrafo precedente, uno podría preguntarse si estos pescadores sintieron alguna identificación con las aves marinas que les proporcionaban las plumas con las que adornaban su frente.

Lo interesante es que estas diademas muestran cierta analogía con el par de "pequeños apéndices parecidos a cuernitos" (Mostny \& Niemeyer 1983: 90, Fig. 59) que llevan en la cabeza algunos tripulantes de balsas en las pictografías de El Médano (fig. 37b-c). ${ }^{31}$ Admito que puede haber reparos a esta comparación: a

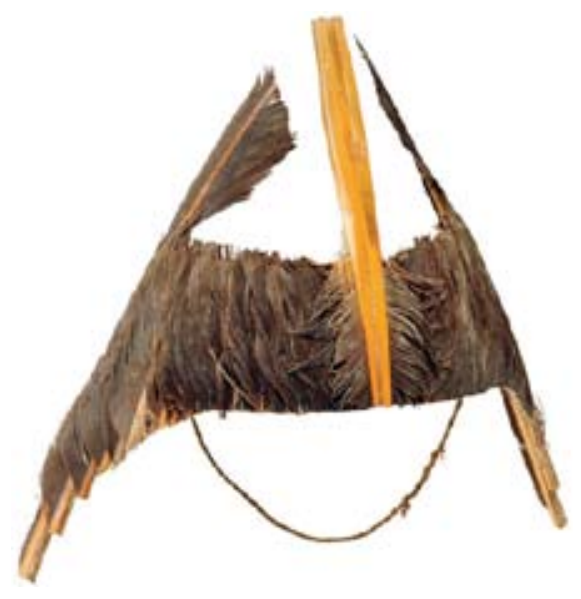

C

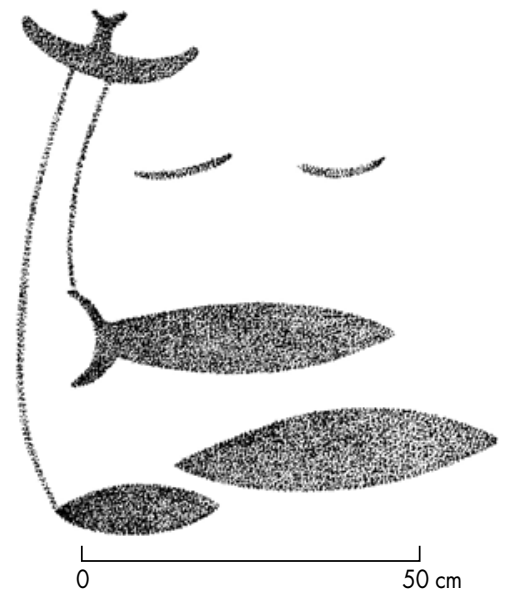

b

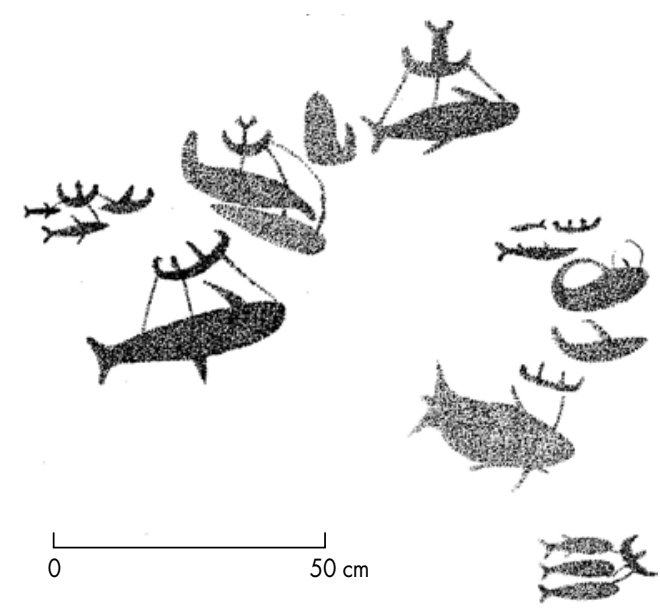

d

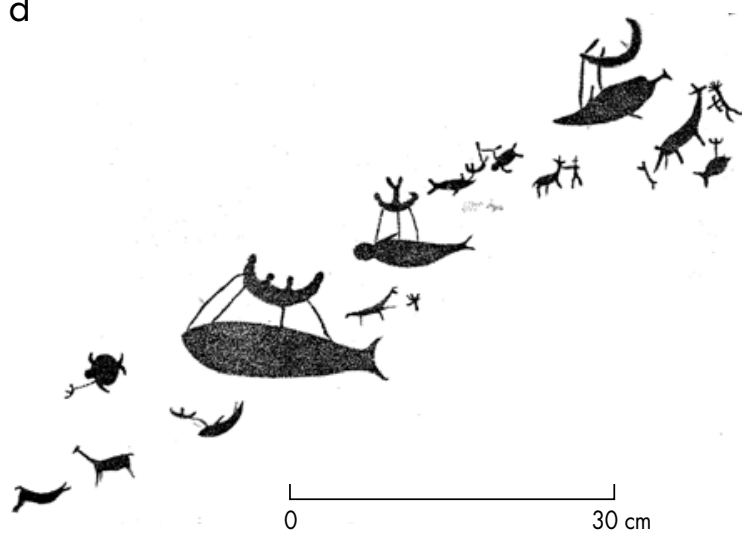

Figura 37. a) Diadema de plumas de pelícanos de los pescadores tardíos del norte de Chile (Museo Chileno de Arte Precolombino $\mathrm{N}^{\circ}$ 0759, alto $21 \mathrm{~cm}$ [Foto: F. Maldonado]); b) panel 29-G; c) panel 20-E; d) panel 43A.

Figure 37. a) Pelican feather headdress of the late fishermen of Northern Chile (Museo Chileno de Arte Precolombino No O759, height $21 \mathrm{~cm}$ [Photo: F. Maldonado]); b) panel 29-G; c) panel 2O-E; d) panel $43 \mathrm{~A}$. 

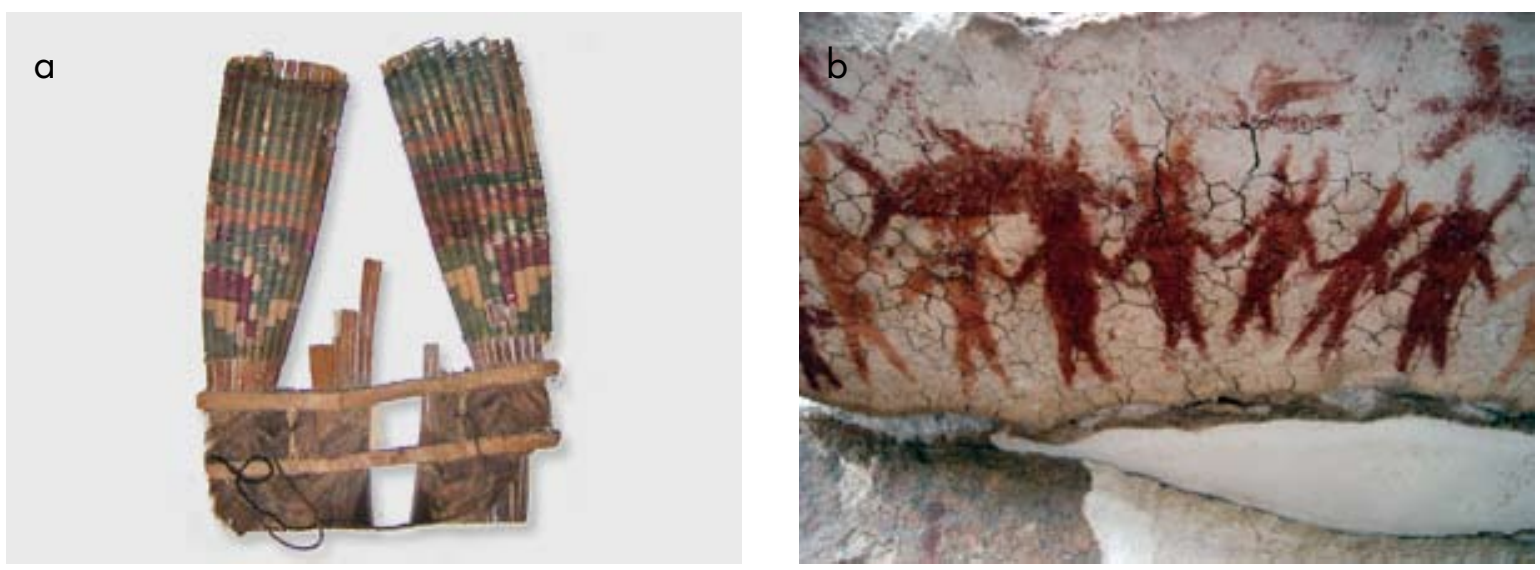

Figura 38. a) Diadema compleja de los pescadores tardíos del norte de Chile (Museo Regional de Iquique [Foto: L Cornejo]); b) Pictografías de Agua Amarga, curso inferior del río Loa (foto: M. Vásquez).

Figure 38. a) Elaborate headdress of the late fishermen of Northern Chile (Museo Regional de Iquique [Photo: L Cornejo]); b) Pictographs of Agua Amarga, lower Loa River (photo: M. Vásquez).

hasta donde se sabe, no se han encontrado diademas de plumas de pelícano en los cementerios de Taltal y los ejemplares exhumados en otras partes presentan por lo general tres apéndices, no dos como los tocados de los balseros. Aun así, llama la atención la consistencia con que el tocado de dos puntas aparece en sitios de arte rupestre con escenas marinas. Por ejemplo, una pictografía reportada por Mario Vásquez en quebrada de Agua Amarga, en el Loa Inferior, muestra una especie marina que comparte el panel con una hilera de varios individuos provistos de apéndices cefálicos parecidos a los de los balseros del Médano, aunque más largos (fig. 38). Se conoce al menos otra hilera similar de individuos en este extenso sitio de arte rupestre. Es más, tanto en Taltape (valle de Camarones) como en Las Lizas, los balseros también llevan tocados de dos puntas (Mostny \& Niemeyer 1983: Figs. 22 y 146). Es decir, la representación del habitante costero como un individuo que usaba este tipo de tocado en el arte rupestre abarca desde el valle de Camarones por el norte hasta la zona de Chañaral-Caldera por el sur. ${ }^{32}$

En El Médano, dice Niemeyer (1985: 145), el hombre se incorpora a la escena con sus enseres de pesca y caza. Por lo tanto, la balsa es otro de los elementos que puede haber operado como diacrítico de filiación cultural. En las pinturas no hay ni un solo caso en que ésta sea representada con sus dos flotadores; la regla es figurarla con sólo uno de ellos y con sus extremos levantados formando una medialuna. ${ }^{33}$ Tripulantes y balsas reflejan así la imagen que este pueblo tenía sobre sí mismo, o más bien, la forma en que los pintores de la quebrada representaban la identidad de estos miembros de la comunidad costera.

\section{La mirada de los otros}

De importancia para explorar la posible elaboración de una "mirada étnica" de los grupos que ocupaban la costa, son las representaciones de balseros en petroglifos y geoglifos localizados desierto adentro, a considerable distancia del litoral. ${ }^{34}$

Ya me he referido al balsero de Taltape, pero habría que agregar los de Tamentica (fig. 39) en la quebrada de Guatacondo y Tarapacá-47 en la quebrada de Tarapacá (Núñez 1986: Fig. 9), Tuina entre Chiuchiu y San Pedro de Atacama (Lindberg 1969: 71-73), y tantos otros referidos por Núñez (1985: 245-246) en una franja del norte de Chile que dista entre 30 y $200 \mathrm{~km}$ de la costa. Se trata en todos los casos de estilos de arte rupestre considerados tardíos, básicamente contemporáneos con el Estilo de El Médano. Pero, ¿se trata en realidad de grabados hechos por habitantes de la costa que viajaban a esos lugares? Digo esto porque se conocen datos sobre pescadores que se internaban profundamente en el desierto, como es el caso de individuos del Período Formativo enterrados cerca de la Oficina Salitrera María Elena (Cases et al. 2008) o de sujetos de la costa inhumados en cementerios de Pica del Período Intermedio Tardío (Núñez, L. 1984b). Mi impresión, sin embargo, es que estas representaciones fueron plasmadas por grupos propiamente andinos. Quizás, caravaneros que habían visto en acción a los balseros que los abastecían de productos del mar y las habrían reproducido en ciertos puntos de sus rutas de tráfico (fig. 40). De otro modo, este tipo de arte rupestre ya se habría reportado en las quebradas cercanas a la costa o en los roqueríos del borde costero, cosa que no ha sucedido hasta ahora. 


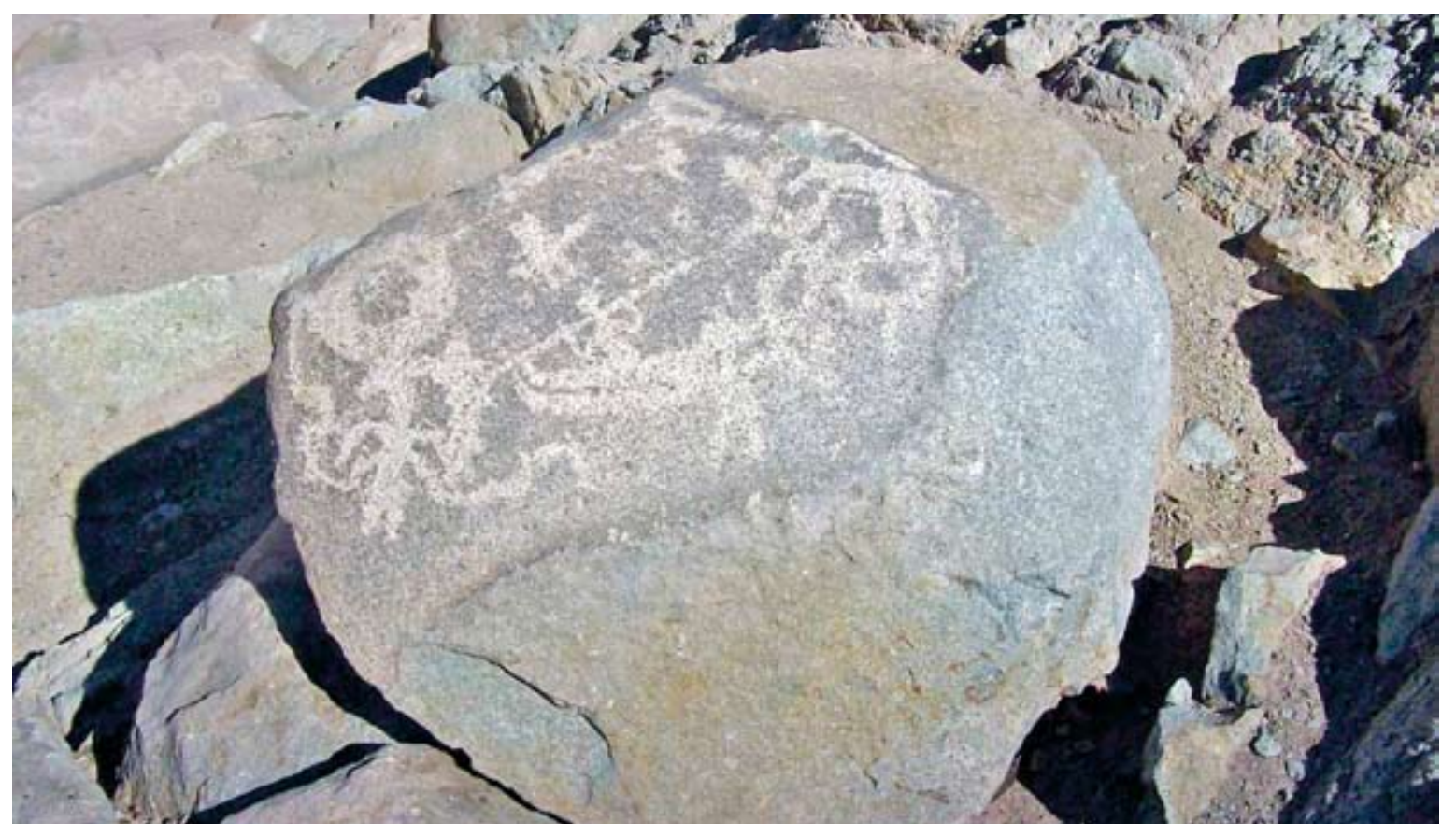

Figura 39. Al centro, balsero en bloque de petroglifos de Tamentica, quebrada de Guatacondo (foto cortesía de H. Gárate). Figure 39. In the center, a raftsman depicted on a boulder with petroglyphs at Tamentica, Guatacondo ravine (photo courtesy of H. Gárate).

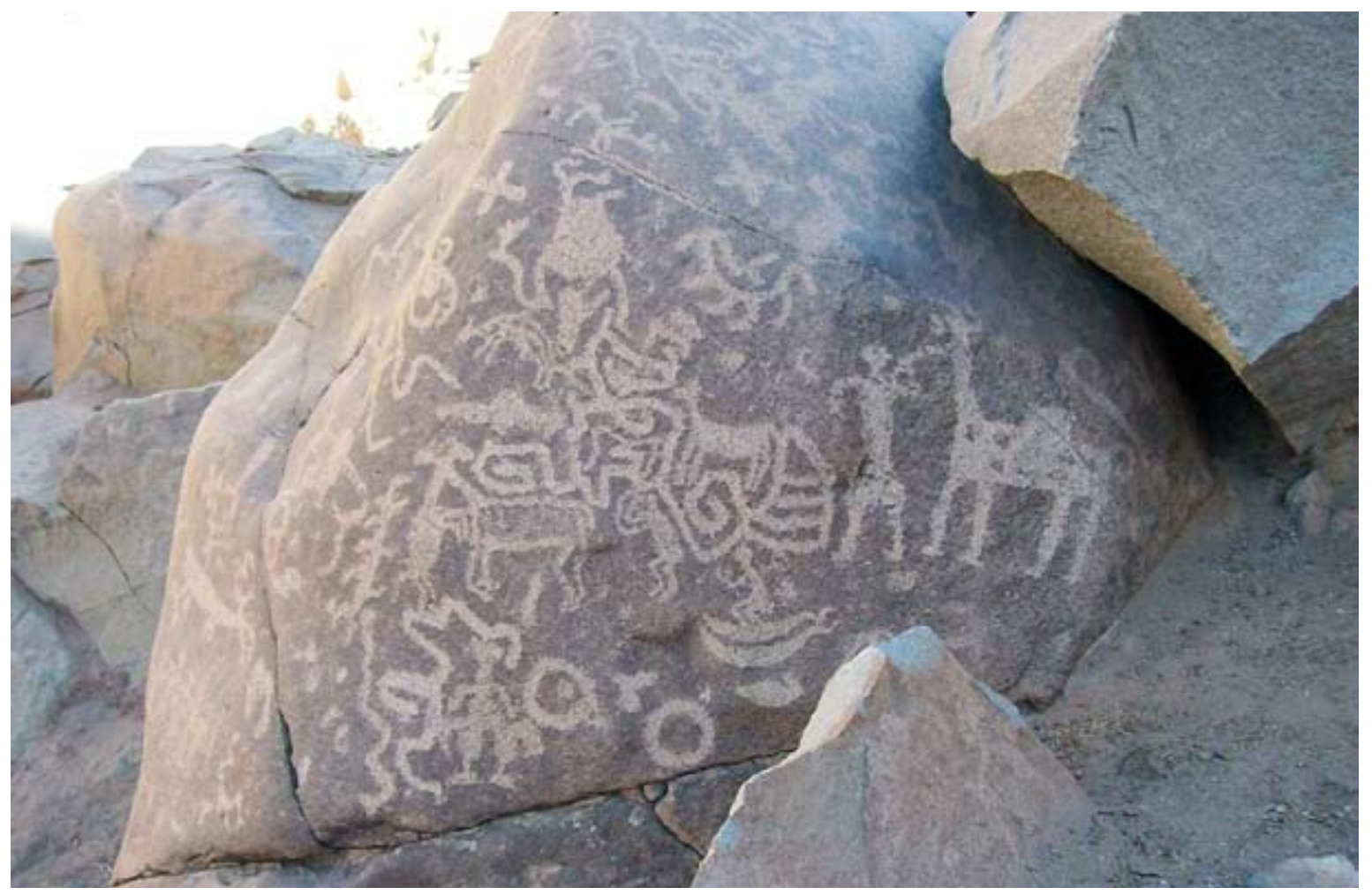

Figura 40. Derecha abajo, balsero; derecha arriba, caravanero en bloque de petroglifo de Tamentica, quebrada de Guatacondo (foto cortesía de H. Gárate).

Figure 40. Lower right, a raftsman; upper right, caravaneer on a petroglyph boulder at Tamentica, Guatacondo ravine (photo courtesy of H. Gárate). 
Es interesante notar a este respecto que los estilos de arte rupestre de estos espacios mediterráneos muestran a las balsas generalmente con sus dos flotadores, tal como hacían a veces los pueblos del interior cuando representaban a los camélidos: con sus cuatro patas a la vez (Berenguer 1996). Además, los tripulantes manipulan pértigas, aparecen de perfil, incluyen cabeza y extremidades, figuran en dinámicas actitudes de navegación, la generalidad de las veces carecen del tocado de dos puntas y rara vez se les representa en acciones de pesca, caza o captura. O sea, en el interior, las características pertinentes seleccionadas por los artistas para representar a las balsas y sus tripulantes, así como las reglas de estilo y convención, son muy distintas a las de los pintores de El Médano. Sobre estas bases, me atrevería a sugerir la hipótesis de que las imágenes de Tamentica y otros lugares del norte profundo reflejan una construcción visual de la alteridad de los habitantes de la costa, es decir, una "mirada" de los pueblos agroganaderos acerca de la identidad de los pescadores/cazadores del litoral. Estos diacríticos o marcadores usados para referirse visualmente a ellos, conllevarían una simplificación más extrema aún que en El Médano: la de concebirlos a todos por igual como "gente de balsas".

\section{CONCLUSIONES}

Como arqueólogos de museos (Joyce 2009), Grete Mostny y Hans Niemeyer mostraron siempre una gran preocupación por difundir los resultados de sus investigaciones arqueológicas a una audiencia más amplia que la de los especialistas. Lamentablemente, esta clase de labor rara vez es bien valorada en el medio académico, lo que es todo un contrasentido. Las razones estriban, en gran parte, en el sistema científico dominante. Por ejemplo, pese a que las autoridades que dirigen la ciencia en Chile han detectado un descenso en las vocaciones científicas de los jóvenes y llevan adelante iniciativas de fomento de la investigación en los escolares, entre otras cosas para contrarrestar esa tendencia (p. e., Programa Explora de Conicyt), sus grupos de trabajo otorgan un mínimo puntaje a esta clase de escritos en la productividad científica de los investigadores cuando éstos concursan por financiamiento para sus proyectos. La señal que transmiten es clara: no vale la pena perder el tiempo en escribir trabajos dirigidos al público general. De ahí que resulte doblemente irónico que, en el caso de un sitio tan clave para la arqueología, como el yacimiento pictográfico de la quebrada El Médano, prácticamente lo único que se haya conocido en 25 años provenga de dos obras de divulgación (Mostny
\& Niemeyer 1983, 1984) y que éstas sean citadas tan a menudo por los propios científicos en sus publicaciones académicas.

Más allá de la simplificación del lenguaje a que obliga el formato de divulgación y a lo preliminar del estudio, se observa en Mostny y Niemeyer un esfuerzo por analizar las pinturas del Médano dentro del marco de una genuina arqueología del arte rupestre y desde una perspectiva inequívocamente antropológica. Hay una preocupación por insertar las pictografías dentro de un concepto organizador como el estilo, situarlas dentro de la secuencia cultural prehispánica del norte de Chile, compararlas con otras expresiones similares para establecer similitudes y diferencias, procurar identificar los referentes de las figuras e intentar lecturas narrativas e interpretativas de ellas con fines explicativos. Más aún: lo que revelan estos dos trabajos y las menciones de Niemeyer en publicaciones posteriores, así como las fotocopias de sus dibujos, es una antigua cultura visual que nos habla de los valores estéticos de sus artífices, de su manera de pensar gráficamente el mundo que los rodeaba y de sus conceptos de sí mismos. Hoy, cuando muchas de las criaturas marinas y terrestres pintadas en El Médano sólo se contemplan, el arte de estos navegantes nos habla de las estrategias materiales y simbólicas que sus comunidades de base pusieron en práctica para resolver el problema de la subsistencia en una costa situada entre uno de los desiertos más secos de la Tierra y uno de los océanos más ricos del planeta.

En este sentido, las imágenes de arte rupestre en los Andes, muchas veces no son meras formas de discurso, sino íconos realizadores. Son tanto imago mundi como anima mundi, puesto que, a través de ellas, se puede actuar sobre la realidad.

Un cuarto de siglo después de las propuestas de Mostny y Niemeyer, hay, por supuesto, más preguntas que respuestas sobre este notable sitio de pictografías. Pero ello es tanto el reflejo del avance experimentado por la arqueología de la costa del norte de Chile y de los estudios de arte rupestre andino, como de la capacidad de ambas obras para sugerir problemas originales, abrir nuevas interrogantes sobre el tema e inspirar investigaciones con los medios y conocimientos que posee nuestra disciplina en la actualidad. De ahí que el legado científico más importante del par de trabajos que comentamos no sea tanto haber erigido al "santuario" de El Médano en un "memorial sagrado de un pueblo desaparecido" (Lewis-Williams 2000: 97). Sino, más seguramente, haber dejado planteada, sin proponérselo, una verdadera agenda de trabajo para los investigadores de comienzos del siglo xxI, varios de cuyos puntos he resaltado a lo largo de 
mi comentario. Aquí sólo quisiera destacar uno: la manera en que estas ideas pueden combinarse con lo que se sabe hoy en día sobre el proceso cultural de las comunidades litoráneas tardías de Taltal y sobre los cambios climáticos de gran escala que afectaron la costa desértica durante la vigencia del Estilo El Médano. En suma, mi análisis sugiere que Mostny y Niemeyer imprimieron a sus obras una orientación y un significado cuya completa proyección, con toda probabilidad, ellos nunca previeron. He ahí mucho del valor heurístico de estos dos trabajos para la arqueología y la ciencia de la imagen.

Digamos para finalizar que estas dos publicaciones constituyen un excelente ejemplo de cómo la investigación arqueológica y la divulgación científica pueden articularse en un "círculo comunicacional" (Joyce 2009) que, mientras educa acerca del significado de la arqueología para la sociedad contemporánea, despierta vocaciones científicas en las nuevas generaciones y legitima socialmente los costos que representa la investigación para el país, cumple, asimismo, con la misión de proveer a los arqueólogos de oportunidades para descubrir o explorar nuevas ideas e hipótesis que enriquecen sus indagaciones y, no pocas veces, originan artículos científicos, tesis de grado, incluso proyectos de investigación.

RECONOCIMIENTOS En el $3^{\text {rd }}$ Southern Deserts Conference: Climate change and the peopling of the southern deserts, Molopo Lodge, Kalahari Desert (16-19 de septiembre, 2008), presenté una versión compacta de este artículo, titulada "Coastal Rock Art in the Atacama Desert: Revisiting the El Médano Paintings". Agradezco a mi colega y amiga María Isabel Hernández Llosas por haberla expuesto a mi nombre en Sudáfrica. La presente versión se vio enriquecida por datos, observaciones o materiales facilitados en diferentes momentos por Iván Solimano, Selva Rubilar, Jorge Bórquez, Lautaro Núñez, José Castelleti, Isabel Cartajena, Patricio Núñez, Rodolfo Contreras, Rolf Foerster, Francisco Gallardo, Oscar Espoueys, Javiera Carmona, José Luis Martínez, Gonzalo Ampuero, Fernando Maldonado, Hugo Gárate, Luis Cornejo, Agustín Llagostera y por los comentarios de los tres evaluadores de este manuscrito. Estoy en deuda con todos ellos. Naturalmente, sólo yo soy responsable de los posibles errores de este artículo y de la manera en que interpreté sus comentarios.

\section{NOTAS}

${ }^{1}$ Existen varias síntesis sobre las ocupaciones costeras del Período Arcaico del norte de Chile (p. e., Llagostera 1989, 1992; Santoro et al. 2005), pero hace falta un panorama actualizado sobre los períodos más tardíos de la secuencia prehistórica del litoral. Para una secuencia cultural prehispánica de Taltal, véase L. Núñez (1984a) y para recientes discusiones sobre la prehistoria de esa área, consúltese (Castelleti (2007) y Salazar et al. (2009). Por cierto, están asimismo los clásicos trabajos de Bird $(1943,1946)$ y Mostny (1964). Una publicación clave sobre embarcaciones prehispánicas es la de L. Núñez (1986; véanse también Bittman [1978] y Carabias [2000], entre varios otros). Vivar (1979 [1558]: 18) hizo una temprana y detallada descripción de la construcción de la balsa de cuero de lobo marino. Otros detalles técnicos sobre este tipo de embarcación provienen de un rescate etnográfico en la caleta de Chañaral de Aceitunas, Región de Atacama (Niemeyer 1965-1966). Últimamente, se ha conocido una carta de Capdeville al investigador ecuatoriano Carlos Larrea, fechada en 1921, en la que describe el proceso de construcción de estas balsas según datos proporcionados por "un viejo chango de Paposo" (Contreras \& Núñez 2009: 91 y ss.). De acuerdo al informante, en esa localidad y en Caleta El Cobre estas embarcaciones estuvieron en uso hasta 1876.

${ }^{2}$ En la tercera década del siglo pasado Capdeville (2008 [1923]: 31) se refería a estas pictografías como "renombradas", sugiriendo que ya en ese entonces eran bastante conocidas. Aparentemente, sólo recorrió una parte de la quebrada, ya que dice que las figuras se encuentran en un trecho de unos $50 \mathrm{~m}$ de longitud, en circunstancias que las pictografías se distribuyen a lo largo de $5 \mathrm{~km}$ de ella. Describe: "1), redes de pescar; tamaño: un cuadradito como de m. 0,$20 ; 2$ ), varias balsas, cuyas dimensiones son: de 5 a 10 centímetros cada una; 3), llamas o guanacos en tropilla; varios grupos; dimensiones: de 3 a 5 centímetro cada llama; 4), varios indios, apuntando a los guanacos con flechas, arrodillados unos, otros lanzando arpones a albacoras, tal vez ballenas; ótros recogiendo con lienza a peces. Dimensiones de los indios: 10 a 15 centímetros de alto" (Capdeville 2008 [1923]: 32).

${ }^{3}$ La parte referida a El Médano es más o menos similar en ambas publicaciones, salvo las ilustraciones, que en el caso del libro incluye 18 dibujos y fotografías en color (Mostny \& Niemeyer 1983: Figs. 56-60, 127, 138, 141-144, 147-149, 161, 163, 166-168), y en el del artículo, sólo siete fotografías en blanco y negro (Mostny \& Niemeyer 1984: 2-5). Es difícil discernir cuáles menciones a El Médano son de cada autor. Es obvio, sin embargo, que si éste relevó las pinturas y presentó a título personal algunos avances en congresos (Niemeyer 1977, 1980), él fue el autor de la mayor parte de esas menciones. Por lo demás, Niemeyer se refirió también a estas pinturas en una obra de divulgación que antecede a su colaboración con Mostny y que no he podido consultar: "H. Niemeyer, 1976-77, Guía del Arte Rupestre Chileno. Manual de los Fascículos 35, 36 y 37 de Expedición a Chile 1876-77, Santiago" (véase Mostny \& Niemeyer 1983: 144).

${ }^{4}$ A partir de 2002, el Museo Augusto Capdeville de Taltal empezó un catastro y relevamiento de las pinturas que ha originado varias publicaciones (Contreras et al. 2007; Contreras et al. 2008; Núñez, P. 2003; Núñez \& Contreras 2003, 2004). Recientemente Francisco Gallardo hizo un nuevo levantamiento de las pictografías como parte de una investigación más amplia del arte rupestre de la Región de Antofagasta. Una síntesis sobre las pinturas de El Médano, orientada a una audiencia no especializada, puede encontrarse en Berenguer (2008a).

5 Para un conciso testimonio personal sobre cómo este investigador operaba en terreno y gabinete, véase Niemeyer (1985: 136-137). Bórquez, por su parte, trabajaba en un comienzo con Jorge Iribarren, Conservador del Museo Arqueológico de La Serena. A principios de los años sesenta se muda a Santiago para estudiar Licenciatura en Arte, momento en que empieza a trabajar con Niemeyer, colaboración que se extendió por más de 40 años.

${ }^{6}$ Hubo al parecer otro dibujante. La biógrafa de Niemeyer, Javiera Carmona (comunicación personal 2007), dice que "durante todo ese año 2002, un sobrino de Hans [...] le estaba haciendo los dibujos en grandes pliegos de papel".

${ }^{7}$ La ausencia en este material del Grupo 26 y de la pictografía de una tortuga capturada por una balsa, cuyos dibujos publicaran Mostny y Niemeyer (1983: Figs. 58 y 147), revela que no todas las ilustraciones de Bórquez están en el legajo de fotocopias. Probablemente, los originales se extraviaron en el proceso de publicación y no pudieron ser fotocopiados. También falta la fotocopia del dibujo del Bloque 19, cuyo croquis aparece en la página 20 del cuaderno "Apuntes de campo". Es quizás importante agregar también que el registro de Niemeyer no fue exhaustivo, acaso por lo corto de la expedición de 1973 (una semana). En una visita que hice a la quebrada en febrero de 2008, guiado por Rodolfo Contreras, 
Director del Museo Augusto Capdeville, Taltal, éste me mostró al menos cuatro bloques de pictografías localizados en la cabecera de la vaguada, que preceden al bloque que Niemeyer designó como el primer panel del yacimiento. Es muy probable, por lo tanto, que aparezcan nuevos paneles de pictografías, inadvertidos en esa expedición. Por ejemplo, hay información sobre pictografías en el curso inferior de la quebrada (Rodolfo Contreras, comunicación personal 2008) y una reciente expedición encontró, efectivamente, algunas al pie del farallón costero, no reportadas por Niemeyer (Francisco Gallardo, comunicación personal 2009).

${ }^{8}$ Su idea de estilo como formado por "técnica, temática y configuración" tiene antecedentes en Willey (1958: 361-385). Al agrupar a estas manifestaciones en estilos y área geográficas, Niemeyer perseguía el mismo objetivo que con las excavaciones que a veces practicaba en depósitos contiguos a paneles de arte rupestre: adscribirlas a desarrollos culturales concretos de una región (p. e., véase Niemeyer 1972). La validez de esta última aproximación ha sido recientemente cuestionada por Troncoso et al. (2008: 13-14), quienes, en otro contexto de análisis, argumentan que no existe una relación necesaria entre imágenes de arte rupestre y depósitos arqueológicos asociados como para transferir la información cronológico-cultural de éstos a aquéllos. Por lo tanto, es recomendable utilizar estas asociaciones espaciales sólo como un criterio de adscripción entre varios otros (Berenguer 2004a: 289-291, 436-447).

9 Núñez y Contreras (2004: 353) sugieren que se usó "óxido ferroso mezclado con resina de cactus", pero no aportan evidencia de respaldo. El reciente hallazgo de Salazar et al. (2009: 112-114, Tabla 1) de una mina "orientada a la extracción de óxidos de hierro" en la ladera norte de la quebrada de San Ramón, al norte del puerto de Taltal, ofrece una posible fuente de los pigmentos utilizados en El Médano, aunque hay que decir que las dataciones radiocarbónicas calibradas obtenidas en las excavaciones estratigráficas de ese yacimiento ( 8250 -8600 AC, 2290-2560 AC y 2040-2460 $\mathrm{AC})$, son demasiado tempranas para la cronología tentativa de estas pictografías (véase infra).

${ }^{10}$ Otro caso podría ser el de un camélido dando a luz una cría (Contreras et al. (2008: 95, abajo), si bien el relevamiento de Niemeyer de esta misma pictografía no reproduce al retoño. En general, toda reproducción es una interpretación visual (Arnheim 1971: 121) y esto es especialmente el caso de la reproducción del arte rupestre, donde el relevamiento de las imágenes en terreno y su traspaso a papel u otro soporte en gabinete siempre contiene las huellas del investigador y de quienes ejecutan el proceso, resultando muchas veces en la distorsión de importantes detalles. Por eso se dice que no hay dos relevamientos iguales; sólo relevamientos de tal o cual persona, en tal o cual fecha (p. e., compárese Mostny \& Niemeyer [1983: Fig. 149] con Contreras et al. [2008: Fig. 4 ]).

${ }^{11}$ José Castelleti (comunicación personal 2007), quien examinó la zona para un estudio de impacto ambiental e hizo su Tesis de Magíster sobre las ocupaciones prehispánicas de la costa de Taltal (Castelleti 2007), sostiene que la plataforma costera en donde desemboca la quebrada El Médano carece en general de restos arqueológicos. Agrega que los sitios más cercanos están a unos $10 \mathrm{~km}$ al norte, en Loreto y Punta de Plata (fig. 13).

12 Núñez (1986: 33) lista 47 menciones a balsas de cuero de lobo en documentos fechados entre $1547-53$ y $1958-70$, que abarcan desde Islay en Perú hasta la desembocadura del río Bío Bío en Chile, con un claro foco de concentración entre las regiones de Tarapacá y Coquimbo. Conviene aclarar que una temprana versión de este artículo de 1986 fue presentada en un congreso en Ecuador en 1979 y otra más reciente iba a ser uno de los aportes del autor a la monografía de Niemeyer sobre El Médano. Según Núñez (comunicación personal 2007) la iniciativa se diluyó con el tiempo. En todo caso, en el legajo de Niemeyer existe un listado de manuscritos de fecha posterior a 1990 ("Título general carpeta: El Médano"), cuya entrada No 8 se titula "Balsas de Pesquería en el Norte de Chile (colaboración de Lautaro Núñez A.)”. Ese manuscrito no ha sido localizado. En algún momento, parece que Niemeyer planificó la monografía como una obra conjunta con L. Núñez, como se desprende del título "H. Niemeyer y L. Núñez, 1982. 'Las pinturas indígenas de la quebrada del Médano. Obra en preparación'” (referida en Mostny \& Niemeyer 1983: 145).

13 "Y cuando estos marineros van en esta balsa navegando y ven que tiene su navio neseçidad de viento, acuden a la tripa y cañuto y soplan hasta que se hincha muy bien / estando él ençima" (Vivar 1979 [1558]: 18).

${ }^{14}$ Un criterio de datación cruzada para las pinturas, no contemplado por Mostny y Niemeyer $(1983,1984)$, podría ser la cronología del arco y la flecha en la zona, toda vez que las escenas de caza de camélidos involucran arqueros. Estas escenas serían posteriores a la fecha de introducción de estos implementos en la zona. L. Núñez (1984: 18, 26-27), por ejemplo, discute el hallazgo de puntas de flechas en los niveles A y B de los depósitos de Cerro Colorado, en el cementerio del Arenal y en otros conchales de Taltal, con fechas que estima anteriores a 300 DC. Con todo, parece que el grueso de este tipo de proyectiles en esa localidad se presenta con posterioridad.

15 Todo esto no significa necesariamente que la práctica de pintar o grabar temas marinos en las rocas haya comenzado recién en el siglo v en el litoral del norte de Chile. Asentamientos del Período Arcaico como Caleta Huelén-42, Las Conchas, Cascabeles, Loreto, El Bronce-1 y otros (véanse, p. e., Contreras et al. 2007; Castelleti 2007), contienen ocupaciones de considerable antigüedad, algunas de las cuales pueden ser las precursoras de esta tradición pictórica. Después de todo, el uso de pigmentos rojos se halla documentado en contextos funerarios Chinchorro (Niemeyer 1985: 146) y a lo largo de gran parte de la secuencia prehispánica de Taltal (Núñez, L. 1984a: 16, 19, 21, 23-24, 33; véase también Salazar et al. 2009: 113-114).

${ }^{16}$ Desgraciadamente, Niemeyer no hizo un mapa de localización de cada panel. Sólo en algunos casos indicó el lado de la quebrada donde se encuentran o la orientación de las facetas decoradas respecto de los puntos cardinales ("Apuntes de campo"). Esto impide realizar un análisis espacial de las pictografías que permita detectar patrones y estudiarlas desde una arqueología del paisaje. Rodolfo Contreras (comunicación personal 2008) practicó un levantamiento con un GPS geodésico, pero no ha publicado aún el plano resultante.

${ }^{17}$ Para más sitios con motivos marinos en petroglifos, pictografías y geoglifos del norte de Chile, véase Niemeyer (1985: 143-145).

${ }_{18}$ Para una lista de especies marinas y del litoral del norte de Chile, véase Niemeyer (1989a: 4). En Niemeyer (1985) se puede encontrar una lista para la zona de Chañaral-Caldera y en Contreras et al. $(2007,2008)$ otra sobre flora y fauna del ambiente costero del área de Taltal.

${ }^{19}$ En sus años postreros, Niemeyer "no sólo estaba trabajando con el tema de El Médano, sino que además intentaba cumplir con otras obligaciones con su grupo de investigación en Copiapó y el proyecto FONDECYT que debía cumplir impostergablemente. Por tanto no tenía una dedicación exclusiva para El Médano y estaba apurado completando otras cosas porque intuía que ya le quedaba poco tiempo" (Javiera Carmona, comunicación personal 2007).

${ }^{20}$ En arte rupestre, las "propiedades intrínsecas" son aquellas características distintivas de forma y postura a partir de las cuales el ser humano se forma una imagen mental de un animal. Los "criterios extrínsecos", en cambio, son aquellos argumentos indirectos o esencialmente externos a la figura, por medio de los cuales el analista identifica una especie (Clottes 1989: 38).

${ }^{21}$ En el artista, dice Clottes (1989: 24), hay un proceso que primero transforma los rasgos intrínsecos de forma y postura de un animal en una imagen mental y luego a ésta en una figura, lo que siempre implica condensación de infinitas características anatómicas del animal en unas pocas líneas y formas.

22 A Cea le parece que también hay representaciones de peces chicos (palometas, atunes y cojinovas) "que aparecen como recolectados por pesca de línea (traccionados desde la boca)" (a este último respecto, véase también Capdeville 2008 [1923: 32]) y 
que las figuras triangulares provistas de cola son rayas, las que nunca aparecen "en relación con una acción de pesca". Núñez y Contreras (2004: 352-353) agregan a la lista posibles tiburones, delfines, tarucas y congrios.

${ }^{23}$ Estas ideas formaban parte de otra colaboración que L. Núñez iba a hacer a la monografía sobre El Médano. En el manuscrito "Prólogo", Niemeyer dice que era "el relato de una expedición de caza de la albacora o pez espada en Iquique con arpones" y confidencia que el trabajo se extravió y no pudo reemplazarlo. Sobre la base de la ya mencionada entrevista al anciano chango de Paposo, en 1921 Capdeville ofrece una descripción de las maniobras de caza, captura y remolque de albacoras desde balsas de cuero de lobo (Contreras \& Núñez 2009: 95).

${ }^{24}$ La minimización de la figura humana con relación al animal es una convención presente en estilos de arte rupestre más tempranos del interior de la región (Berenguer 1996) que apoya la idea de un cierto conservatismo de las comunidades marítimas tardías de la costa de Taltal, es decir, una continuidad en el tiempo de los modos de vida arcaicos (Núñez, L. 1984a; Castelleti 2007; Salazar et al. 2009)

${ }^{25}$ Larraín (1974: 71) duda que la caza de ballenas por los changos haya sido por lo general una faena colectiva, pero las pictografías de El Médano muestran varias escenas de captura desde balsas con dos o más tripulantes. Además, en numerosas ocasiones las balsas aparecen arrastrando tres o más de estos cetáceos, resultando improbable que su captura haya sido obra de "navegantes solitarios o en escaso número". No sé si las verdaderas flotillas que se observan en las escenas más complejas reflejan operaciones conjuntas de captura, pero, de seguro, las maniobras de caza de grandes cetáceos requerían cooperación entre varios individuos.

${ }^{26}$ Los antecedentes teóricos más directos de esta incursión de los autores en los aspectos connotativos de las imágenes, parecen estar en los planteamientos de Mostny (1969) sobre una función mágico-religiosa del arte rupestre del Alto Loa y, especialmente, en la lectura de Niemeyer (1977) del artículo de Van Kessel (1976) acerca de las pinturas del norte de Chile como imágenes votivas. Esta última idea corresponde a la noción de que los pueblos andinos poseen una ritualidad desiderativa que los lleva a prefigurar simbólicamente lo que anhelan: en este caso, ciertos recursos marinos y terrestres. Se trata de lo que en otro contexto Martínez (2004) ha denominado la eficacia mágico-religiosa del arte rupestre (véase también Berenguer 2004b).

${ }^{27}$ El "Chelo", un ex buzo de Taltal, cuenta que intentó acceder a la quebrada subiendo el farallón desde la costa, pero que al cruzar la capa de niebla, ésta era tan espesa y el ascenso se tornaba tan peligroso, que desistió de continuar.

${ }^{28}$ La escasez del vital elemento es tan acuciante, que se ha observado que los pescadores "changos" actuales beben el agua dulce que contienen los pescados crudos (Lindberg 1967: 11-12). La misma fuente señala que estos pescadores utilizan plantas que acumulan agua en sus tallos y que colocan "piedras lajas ligeramente inclinadas contra una piedra hueca en lugares donde pasa la neblina o camanchaca" para captar el agua condensada.

${ }^{29}$ En vena narrativa y con una prosa abiertamente lírica, Lehnert (1997: 21) procura capturar el discurso identitario de los pintores de El Médano: "Ese chango nos está contando que él y su banda dominan el mar, que se embarcan en sus balsas mar adentro para buscar afanosamente su sustento, que señorean los 'tumbos' [olas grandes], que pescan con anzuelo pero que también cazan a la albacora y al lobo marino en violenta lucha oceánica. En el centro de ese universo marino está el hombre, sobresaliendo con marcada nitidez como el señor del mar, como el dominador del piélago, como el navegante de mareas".

${ }^{30}$ Véase, a propósito, la discrepancia entre Niemeyer (1985: 145) y otros autores acerca de si unas pictografías en rojo en una roca de la estancia de El Panul (Región de Coquimbo) son figuras antropomorfas o lobos marinos.

${ }^{31}$ Para una opinión diferente, véase Contreras y colaboradores (2008: 95; también Contreras et al. 2009), quienes sostienen que tales apéndices corresponden a los brazos en alto de tripulantes expresando júbilo por la captura.

${ }^{32}$ La imagen del cazador de guanacos, en cambio, es diferente: aparte de que se le representa con cabeza, brazos y piernas, en algunos casos lleva un tocado formado por varios apéndices radiantes, parecido a un penacho de plumas.

33 Contreras et al. (2008: 94, Lám. 2-3) identifican varias balsas de extremos bifurcados, rasgo en general no presente en los dibujos de Niemeyer. Las denominan "balsas cola de pescado" y las interpretan como embarcaciones míticas. Una interpretación alternativa es que esta variación corresponda a balsas reales, cuyos flotadores de cuero conservaban las extremidades inferiores de los lobos. En todo caso, las balsas reproducidas en grabados históricos poseen una gran variedad de forma y tamaño, pero no presentan este hipotético diseño.

${ }^{34}$ Por "mirada étnica" Martínez (1995) entiende "una forma de 'ver' y 'representar' al otro que de una u otra manera va generando una mirada y una forma de referencia, de decir, sobre la cual en -un momento- ya no se reflexiona sino que, simplemente, se usa o se impone".

\section{REFERENCIAS}

Allendes, J. L., 2000. El Niño Oscilación Sur (ENSO) < http://biogeografia.tripod.com/Resto/Juan/elnino.html>

Arnheim, R., 1971. Arte, percepción visual. Buenos Aires: eudeba.

Berenguer, J., 1996. Identificación de camélidos en el arte rupestre de Taira: ¿Animales silvestres o domésticos? Chungara 28 (1-2): 85-114.

— 2004a. Caravanas, interacción y cambio en el desierto de Atacama. Santiago: Sirawi Ediciones.

- 2004b. Cinco milenios de arte rupestre en los Andes atacameños: Imágenes para lo humano, imágenes para lo divino. Boletín del Museo Chileno de Arte Precolombino 9: 167-182, Santiago.

— 2006. Señales en la cabeza. Los tocados de Wirakocha en el norte de Chile / Head emblems. Wirakocha's headdresses in Northern Chile. En Gorros del desierto / Headdresses from the desert, L. Cornejo, Ed., pp. 8-90, catálogo de exposición. Santiago: Museo Chileno de Arte Precolombino.

- 2008a. Arte rupestre de mar y tierra / Rock art of land and sea. En Pescadores de la niebla. Los changos y sus ancestros / Fishermen of the fog. The Changos and their ancestors, L. Cornejo, Ed., pp. 52-65, catálogo de exposición. Santiago: Museo Chileno de Arte Precolombino.

- 2008b. Innovaciones tecnológicas y conquista económica del mar / Technological innovation and the economic conquest of the sea. En Pescadores de la niebla. Los changos y sus ancestros / Fishermen of the fog. The Changos and their ancestors, L. Cornejo, Ed., pp. 22-29, catálogo de exposición. Santiago: Museo Chileno de Arte Precolombino.

-2008c. $18-27^{\circ}$ Latitud Sur: Entre desierto y océano/18- $27^{\circ}$ Latitude South: Between the desert and the ocean. En Pescadores de la niebla. Los changos y sus ancestros / Fishermen of the fog. The Changos and their ancestors, L. Cornejo, Ed., pp. 10-21, catálogo de exposición. Santiago: Museo Chileno de Arte Precolombino.

Berenguer, J.; A. Deza; A. Román \& A. Llagostera, 1986. La secuencia de Myriam Tarragó para San Pedro de Atacama: Un test por termoluminiscencia. Revista Chilena de Antropología 5: $83-120$

BIRD, J. B., 1943. Excavations in northern Chile. Anthropological Papers of the American of Natural History, Vol. 38, $\mathrm{N}^{\circ} 4$, New York.

- 1946. The cultural sequence of the north Chilean Coast. En Handbook of South American Indian, J. Steward, Ed., Vol. II, pp. 587-597. Washington, D.C.: Smithsonian Institution. 
Bittman, B., 1978. Fishermen, mummies and balsa rafts on the coast of Northern Chile. El Dorado 3 (3): 60-99.

— 1984a. El Proyecto Cobija: investigaciones antropológicas en la costa del desierto de Atacama (Chile). En Simposio Culturas Atacameñas, B. Bittman, Ed., pp. 99-146. Antofagasta: Universidad del Norte.

— 1984b. El Programa Cobija: Investigaciones antropológico-multidisciplinarias en la costa Centro Sur Andina: Notas etnohistóricas En Contribuciones al Estudio de los Andes Centrales, S. Masuda, Ed., pp. 101-148. Tokio: Universidad de Tokio.

Caiceo, J. C.; J. Jara; L. Lazo; R. Perucci \& M. Villarroel, 1985. Arte rupestre, testimonio de integración. Revista Creces 11 (5): 3-7, Santiago.

CAPDEville, A., 2008 [1923]. Un cementerio Chincha-Atacameño en Punta Grande, Taltal. Taltalia - Revista del Museo Augusto Capdeville Rojas de Taltal 1: 25-45.

Carabias, D., 2000. Navegación prehispánica en el norte de Chile: Una contribución al estudio de las prácticas náuticas en las áreas Andes Centro-Sur y Meridional. Revista Werkén 1: 31-54.

Castelleti, J., 2007. Patrón de asentamiento y uso de recursos a través de la secuencia ocupacional prehispana en la costa de Taltal. Tesis para optar al grado de Magíster en Arqueología, Universidad Católica del Norte / Universidad de Tarapacá.

Carmona, J., 2003. Archivos de suelo: Hans Niemeyer y la arqueología científica en Chile. Santiago: Coedición La Huella / Logos Group / Ernesto Carmona Editor.

Cases, B.; C. Rees; G. Pimentel; R. Labarca \& D. Leiva, 2008. Sugerencias desde un contexto funerario en un 'espacio vacío' del desierto de Atacama. Boletín del Museo Chileno de Arte Precolombino 13 (1): 51-70

Cerveluino, M., 1985. Evaluación del arte rupestre en la III Región Atacama. En Estudios en arte rupestre, C. Aldunate, J. Berenguer \& V. Castro, Eds., pp. 355-371. Santiago: Museo Chileno de Arte Precolombino.

Clottes, J. C., 1989. The identification of human and animal figures in European Palaeolithic art. En Animals into art, H. Morphy, Ed., pp. 21-56. Londres: Unwin Hyman / One World Archaeology.

COLLE, R., 1998. Iniciación al lenguaje de la imagen. $2^{a}$ Edición. Santiago: Ediciones Universidad Católica de Chile.

Contreras, R. \& P. NúÑEz, 2009. A propósito de una miniatura de balsa en Taltal, contemporánea con Chinchorro. Taltalia - Revista del Museo Augusto Capdeville Rojas de Taltal 2: 98-110.

CONTRERAS, R.; P. NúŃEz \& O. Rodríguez, 2008. El Médano: Reflexiones antropológicas en torno a la cosmovisión de los habitantes prehispanos de la costa sur del Norte Grande. Taltalia - Revista del Museo Augusto Capdeville Rojas de Taltal 1: 87-122.

Contreras, R.; J. Cruz; A. Llagostera; H. Garcés; P. Núñez; O. Rodríguez; H. Gárate \& G. Palacios, 2007. Los Bronces-1. Un asentamiento de 5.500 años en la costa de Taltal. Taltal: Museo Augusto Capdeville.

Gallardo, F.; C. Sinclaire \& C. Silva, 1999. Arte rupestre, emplazamiento y paisaje en la cordillera del desierto de Atacama. En Arte rupestre en los Andes de Capricornio / Rock art in the Andes of Capricorn, J. Berenguer \& F. Gallardo, Eds., pp. 57-96. Santiago: Museo Chileno de Arte Precolombino.

Gombrich, E. H., 1999. La historia del arte. Buenos Aires: Editorial Sudamericana.

HorTa, H., 2000. Diademas de plumas en entierros de la costa del norte de Chile: ¿Evidencias de la vestimenta de una posible parcialidad pescadora? Chungara 32 (2): 235-243.

IGM, 1990. Geografía de Chile - Tomo II Región de Antofagasta Santiago: Instituto Geográfico Militar.

IWASAKI, F., 2007. El rostro fuera de la caverna. La Tercera Cultura, sábado 1 de diciembre, p. 5, Santiago.

JoYCE, R. A., 2009. Working in museums as an archaeological anthropologist. Archaeological Papers of the American Anthropological Association 13 (1): 99-109

Larraín, H., 1974. Demografía y asentamientos de los pescadores costeros del sur peruano y norte chileno, según informes del cronista Antonio Vásquez de Espinosa (1617-1618). Norte Grande (1) 1: 55-80.

LeHnert, R., 1997. Changos: Navegantes de mareas. Antofagasta: Instituto de Investigaciones Antropológicas, Universidad de Antofagasta.

Lewis-Williams, J. D., 2000. Discovering Southern African rock art. $3^{\text {a }}$ Edición. Cape Town \& Johannesburg: David Philip Publishers Ltd.

LindBERG, I., 1967. Algunas notas sobre changos actuales en la costa de Antofagasta. Museo Regional 1 (3): 5-17.

- 1969. Conchi Viejo. Una capilla y ocho casas. En Actas del $V$ Congreso Nacional de Arqueología, pp. 59-73. La Serena: Museo Arqueológico de La Serena.

LizÁrRaga, R. DE, 1968 [1605?]. Descripción breve de toda la tierra del Perú, Tucumán, Río de la Plata y Chile. B.A.E. Madrid: Editorial Atlas.

Llagostera, A., 1989. Pesca y caza marítima (9.000 a 1.000 a.C.) En Culturas de Chile. Prehistoria, J. Hidalgo, V. Schiappacasse, H. Niemeyer, C. Aldunate \& I. Solimano, Eds., pp. 57-79. Santiago: Editorial Andrés Bello.

- 1990. La navegación prehispánica en el norte de Chile: Bioindicadores e inferencias teóricas. Chungara 24/25: 37-51.

— 1992. Early occupations and the emergence of fishermen on the Pacific coast of South America. Andean Past 3: 87-109.

Martínez, J. L., 1995. Entre plumas y colores. Aproximaciones a una mirada cuzqueña sobre la puna salada. Memoria Americana 4: 33-56, Buenos Aires

- 2004. ¿Arte rupestre o sistemas de comunicación visual? Actas del $5^{\circ}$ Congreso de Antropología Chilena, San Felipe, pp. 339347. Santiago: Colegio de Antropólogos de Chile.

Mostny, G., (Comp.), 1964. Arqueología de Taltal. Epistolario de Augusto Capdeville con Max Uble y otros arqueólogos e bistoriadores, Tomos I y II. Santiago: Fondo Histórico y Bibliográfico José Toribio Medina.

— 1969. Ideas mágico-religiosas de los Atacamas. Boletín del Museo Nacional de Historia Natural xxxi: 133-140.

Mostny, G. \& H. Niemeyer, 1983. Arte rupestre chileno. Santiago: Ministerio de Educación, Serie el Patrimonio Cultural Chileno.

— 1984. Arte rupestre en El Médano, in Región. Revista Creces 9 (5): 2-5, Santiago

Niemeyer, H., 1965-1966. Una balsa de cueros de lobo de la caleta de Chañaral de Aceitunas (Prov. de Atacama, Chile). Revista Universitaria, Año L-LI, Fascículo II, Anales de la Academia Chilena de Ciencias Naturales 28-29: 257-269, Santiago.

— 1972. Las pinturas rupestres de la sierra de Arica. Santiago: Editorial Jerónimo de Vivar.

— 1977. Variación de los estilos de arte rupestre en Chile. En Actas del VII Congreso de Arqueología de Chile, Altos de Vilches, vol. II, pp. 649-660. Santiago: Editorial Kultrún.

— 1980. Arte rupestre en la República de Chile. Actas de las Primeras Jornadas de Arte Rupestre de la Provincia de San Luis, pp. 67-77. San Luis: Dirección Provincial de Cultura, San Luis.

— 1985. El yacimiento de petroglifos Las Lizas (Región de Atacama, Provincia de Copiapó, Chile). En Estudios en arte rupestre, C. Aldunate, J. Berenguer \& V. Castro, Eds., pp. 131-171. Santiago: Museo Chileno de Arte Precolombino.

- 1989a. El escenario geográfico. En Culturas de Chile. Prehistoria, J. Hidalgo, V. Schiappacasse, H. Niemeyer, C. Aldunate \& I. Solimano, Eds., pp. 1-12. Santiago: Editorial Andrés Bello. 1989b. Los canastos para pescar en la quebrada El Médano. Museos 5: 2. Santiago: Dibam.

s.f. "Apuntes de campo".

s.f. "Crónica del rescate". s.f. "El Estilo El Médano".

s.f. "Los peces (colaboración del Dr. Alfredo Cea)". s.f. "Operación de la balsa". 
- s.f. "Naturaleza de los pigmentos". s.f. "Prólogo".

s.f. "Título general carpeta: El Médano".

NúÑEz, L., 1984a. Secuencia de asentamientos prehistóricos del área de Taltal. Revista Futuro 8: 24-71, Liceo Taltal.

- 1984b Tráfico de complementariedad de recursos entre las tierras altas y el Pacífico en el Área Centro Sur Andina. Tesis doctoral inédita, Universidad de Tokio.

— 1985. Petroglifos y tráfico de caravanas en el desierto chileno. En Estudios en arte rupestre, C. Aldunate, J. Berenguer \& V. Castro, Eds., pp. 243-264. Santiago: Museo Chileno de Arte Precolombino.

- 1986. Balsas prehistóricas del litoral chileno: Grupos, funciones y secuencia. Boletín del Museo Chileno de Arte Precolombino 1: 11-35, Santiago.

— 1987. Tráfico de metales en el Área Centro-Sur Andina: Factos y expectativas. Cuadernos del Instituto Nacional de Antropología 12: 73-105, Buenos Aires.

NúÑEZ, L. \& J. VARELA, 1968. Sobre los recursos de agua y el poblamiento prehispánico de la costa del Norte Grande de Chile. Estudios Arqueológicos 3-4: 7-41, Antofagasta.

NúÑez, P., 2003. Vivir el mar. Antofagasta: Universidad de Antofagasta.

Núñez, P. \& R. Contreras, 2003. Pinturas prehispanas de Taltal. Antofagasta: Proyecto FondART 160966/1002

- 2004. El arte rupestre de Taltal, norte de Chile. En Actas del $5^{\circ}$ Congreso de Antropología Chilena, San Felipe, pp. 348-357. Santiago: Colegio de Antropólogos de Chile.

Ortlieb, L., 1995. Eventos El Niño y episodios lluviosos en el desierto de Atacama: El registro de los últimos dos siglos. Bulletin de l'Institut Français d'Etudes Andines 24 (3): 519-537.

Ortlieb, L.; R. Escribano; R. Follegati; O. Zúñiga; I. Kong; L. RodrígueZ; J. VALdés; N. GuZmÁn \& P. IRATChET, 2000. Recording of ocean-climate changes during the last 2,000 years in a hypoxic marine environment of northern Chile $\left(23^{\circ} \mathrm{S}\right)$. Revista Chilena de Historia Natural 73 (2): 221-242.

Quiroz, D., 1989. La pesca con canastos entre los yámana del Canal Beagle. Museos 4: 9-12, Santiago: DiBam.
Rojas Muñoz, J., 2005. Arte de los indígenas de Atacama. Santiago: Editorial Magisterio.

Salazar, D.; V. Castro; H. Salinas \& V. Varela, 2009. Nuevas investigaciones sobre la prehistoria y la antigua minería de Taltal. Taltalia - Revista del Museo Augusto Capdeville Rojas de Taltal 2: 111-118.

Santoro, C.; B. Arriaza; V. Standen \& P. Marquet, 2005. People of the coastal Atacama Desert: Living between sand dunes and waves of the Pacific Ocean. En Desert peoples. Archaeological perspectives, P. Veth, M. Smith \& P. Hiscock, Eds., pp. 243-260. Carlton: Blackwell Publishing.

Troncoso, A.; F. Armstrong; F. Vergara; P. Urzúa \& P. Larach, 2008. Arte rupestre en el Valle El Encanto (Ovalle, Región de Coquimbo): Hacia una revaluación del sitio-tipo del Estilo Limarí. Boletín del Museo Chileno de Arte Precolombino 13 (2): 9-36.

VAN Kessel, J., 1976. La pictografía rupestre como imagen votiva (Un intento de interpretación antropológica). En Homenaje al Dr. R. P. Gustavo Le Paige, L. Núñez, Comp., pp. 143-226. Antofagasta: Universidad del Norte.

- 1986. Diccionario de pesca artesanal del Norte Grande de Chile. Iquique: Universidad Libre de Ámsterdam / Centro de Investigaciones de la Realidad del Norte.

VÁsquez de EspinosA, A., 1948 [1628-1629]. Compendio y descripción de las Indias Occidentales. Transcrito del manuscrito original por C. U. Clark. Smithsonian Miscellaneous Collections, Vol. 108. Washington D. C.: Smithsonian Institution.

Villafañe, J \& N. Mínguez, 2000. Principios de teoría general de la imagen. Madrid: Ediciones Pirámide.

VIVAR, G. de, 1979 [1558]. Crónica y relación copiosa y verdadera de los Reinos de Chile. L. Sáez-Godoy, Ed., Bibliotheca IberoAmericana. Berlin: Colloquium Verlag.

WILLEY, G. R., 1958, Archaeological theories and interpretation: New World. En Anthropology Today, A. L. Kroeber, Ed., pp. 361-385, $5^{\text {a }}$ Edición. Chicago: The University of Chicago Press.

Williams, A.; C. Santoro; M. Smith \& C. Latorre, 2008. The impact of ENSO in the Atacama Desert and Australian arid zone: Exploratory time-series analysis of archaeological records. Chungara 40 Número Especial: 245-259. 